medRxiv preprint doi: https://doi.org/10.1101/2021.07.29.21261325; this version posted August 1, 2021. The copyright holder for this preprint (which was not certified by peer review) is the author/funder, who has granted medRxiv a license to display the preprint in perpetuity.

It is made available under a CC-BY 4.0 International license .

\title{
Specialized interferon ligand action in COVID19
}

Matthew D. Galbraith ${ }^{1,2}$, Kohl T. Kinning ${ }^{1}$, Kelly D. Sullivan ${ }^{1,3}$, Paula Araya ${ }^{1}$, Keith P. Smith ${ }^{1}$, Ross E. Granrath$^{1}$, Jessica R. Shaw ${ }^{1}$, Ryan Baxter ${ }^{4}$, Kimberly R. Jordan ${ }^{4}$, Seth Russell ${ }^{5}$, Monika

Dzieciatkowska $^{6}$, Julie A. Reisz ${ }^{6}$, Fabia Gamboni $^{6}$, Francesca Cendali ${ }^{6}$, Tusharkanti Ghosh ${ }^{7}$, Andrew A. Monte $^{8}$, Tellen D. Bennett ${ }^{9}$, Kirk C. Hansen ${ }^{6}$, Elena W.Y. Hsieh ${ }^{4,10}$, Angelo D'Alessandro ${ }^{6}$, and Joaquin M. Espinosa ${ }^{1,2^{*}}$

\section{Affiliations:}

${ }^{1}$ Linda Crnic Institute for Down Syndrome, University of Colorado Anschutz Medical Campus; Aurora, CO, USA.

${ }^{2}$ Department of Pharmacology, University of Colorado Anschutz Medical Campus; Aurora, CO, USA. ${ }^{3}$ Department of Pediatrics, Section of Developmental Biology, University of Colorado Anschutz Medical Campus; Aurora, CO, USA.

${ }^{4}$ Department of Immunology and Microbiology, University of Colorado Anschutz Medical Campus; Aurora, CO, USA.

${ }^{5}$ Data Science to Patient Value, University of Colorado Anschutz Medical Campus; Aurora, CO, USA. ${ }^{6}$ Department of Biochemistry and Molecular Genetics, University of Colorado Anschutz Medical Campus; Aurora, CO, USA.

${ }^{7}$ Department of Biostatistics and Informatics, Colorado School of Public Health; Aurora, CO, USA.

${ }^{8}$ Department of Emergency Medicine, University of Colorado Anschutz Medical Campus; Aurora, CO, USA.

${ }^{9}$ Department of Pediatrics, Sections of Informatics and Data Science and Critical Care Medicine, University of Colorado Anschutz Medical Campus; Aurora, CO, USA.

${ }^{10}$ Department of Pediatrics, Division of Allergy/Immunology, University of Colorado Anschutz Medical Campus; Aurora, CO, USA.

${ }^{*}$ Corresponding author. joaquin.espinosa@cuanschutz.edu 
medRxiv preprint doi: https://doi.org/10.1101/2021.07.29.21261325; this version posted August 1, 2021. The copyright holder for this preprint (which was not certified by peer review) is the author/funder, who has granted medRxiv a license to display the preprint in perpetuity.

It is made available under a CC-BY 4.0 International license.

\section{ABSTRACT}

The impacts of IFN signaling on COVID19 pathology are multiple, with protective and harmful effects being documented. We report here a multi-omics investigation of IFN signaling in hospitalized COVID19 patients, defining the biosignatures associated with varying levels of 12 different IFN ligands. Previously we showed that seroconversion associates with decreased production of select IFN ligands (Galbraith et al, 2021). We show now that the antiviral transcriptional response in circulating immune cells is strongly associated with a specific subset of ligands, most prominently IFNA2 and IFNG. In contrast, proteomics signatures indicative of endothelial damage associate with levels of IFNB and IFNA6. Differential IFN ligand production is linked to distinct constellations of circulating immune cells. Lastly, IFN ligands associate differentially with activation of the kynurenine pathway, dysregulated fatty acid metabolism, and altered central carbon metabolism. Altogether, these results reveal specialized IFN ligand action in COVID19, with potential diagnostic and therapeutic implications.

\section{IMPACT STATEMENT}

Analysis of multi-omics signatures associated with 12 different IFN ligands reveals their specialized action in COVID19. 
medRxiv preprint doi: https://doi.org/10.1101/2021.07.29.21261325; this version posted August 1, 2021. The copyright holder for this preprint (which was not certified by peer review) is the author/funder, who has granted medRxiv a license to display the preprint in perpetuity.

It is made available under a CC-BY 4.0 International license .

\section{INTRODUCTION}

The impact of Interferon (IFN) signaling on the course of COVID19 pathology has been the subject of much investigation, with both protective and deleterious effects being reported. The protective effects of IFN signaling are demonstrated by studies showing that severe COVID19 is associated with decreased IFN signaling (1), the presence of auto-antibodies blocking IFN ligand action (2), and genetic variants that impair IFN signaling (3). However, Type I IFN signaling has been established as a driver of pathology in mouse models of both SARS-CoV-1 and SARS-CoV-2 infections $(4,5)$, and Type I and III IFN signaling have been implicated in disruption of lung barrier function and increased susceptibility to secondary bacterial infections in mice (6). This ambivalence has fueled the design of seemingly contradictory clinical trials using either IFN ligands (7) or agents that block IFN signaling, such as JAK inhibitors (8). This duality is further illustrated by studies showing that genetic variants leading to low expression of the Type I IFN receptor IFNAR2 or high expression of TYK2, a protein kinase required for Type I IFN signaling, are associated with life-threatening disease (9). Therefore, it is possible that context-dependent variations in IFN signaling may attenuate or exacerbate COVID19 pathology in different settings. Indeed, retrospective analysis of IFN- $\alpha 2 b$ treatment in COVID19 showed that early administration was associated with reduced mortality, whereas late administration was associated with increased mortality (10).

There are three major types of IFN signaling defined by the transmembrane receptors and downstream signaling kinases involved (11). Type I IFN involves IFN alpha, beta, epsilon, kappa, and omega ligands, the IFNAR1 and IFNAR2 receptors, and the downstream kinases JAK1 and TYK2. Type II IFN signaling involves the gamma ligand, the IFNGR1 and IFNGR2 receptors, and the downstream kinases JAK1 and JAK2. Type III IFN signaling involves the lambda ligands, the IFNLR1 and IL10RB receptors, and the JAK1 and TYK2 kinases. However, this classification fails to capture the biological complexity created by the differential effects of distinct ligands acting through the same receptors. This is most evident by the differential effects of alpha ligands and IFNB1 within Type I signaling (12). Even within alpha ligands there is significant heterogeneity in cellular source, site of action, and downstream effects (12). Nevertheless, in the context of lung viral infections, it is accepted that select alpha and lambda 
medRxiv preprint doi: https://doi.org/10.1101/2021.07.29.21261325; this version posted August 1, 2021. The copyright holder for this preprint (which was not certified by peer review) is the author/funder, who has granted medRxiv a license to display the preprint in perpetuity.

It is made available under a CC-BY 4.0 International license .

ligands are first responders in the antiviral response due to their induced expression upon engagement of pattern recognition receptors in the lung epithelium (13). In the context of SARS-CoV-2 infections, little is known about the functional specialization of different IFN ligands and their relative contributions to different aspects of the ensuing pathology. Furthermore, SARS-CoV-2 has evolved diverse strategies to evade IFN signaling (14), and clinical trials for IFN alpha, beta, gamma and lambda ligands have been completed or are under way, even in combinations, but definitive results leading to approval for clinical use are pending (15).

Within this context, we report here a multi-omics analysis of IFN signaling in hospitalized COVID19 patients. This investigation includes a comprehensive examination of the whole blood transcriptome, plasma proteome, anti-SARS-CoV-2 antibodies, peripheral immune cell repertoire, and plasma and red blood cell metabolomes in relationship to levels of 12 different circulating IFN ligands. In hospitalized patients with moderate COVID19 pathology, transcriptome-based IFN scores are highly variable and significantly associated with levels of a subset of circulating IFN ligands such as IFNA2 and IFNG, but not so IFNA6 or IFNB1. Likewise, plasma proteomic signatures are also differential among ligands. For example, whereas IFNG and other ligands are clearly associated with production of monocyte activating and mobilizing chemokines, IFNA6 and IFNB1 levels associate with markers of platelet degranulation and endothelial damage. Furthermore, IFN ligands display differential relationships with immunoglobulins targeting SARS-CoV-2, revealing that seroconversion associates with decreased production of a select subset of ligands. This shift in IFN ligand production upon seroconversion is accompanied by significant changes in the immune cell types associated with production of the various ligands. For example, whereas IFNA10 is strongly associated with levels of Th1 CD4 T cells, CD56 bright NK cells and plasmacytoid dendritic cells, its levels are strongly anti-correlated with levels of circulating plasmablasts. Lastly, we revealed specific metabolomic signatures associated with diverse ligands. Whereas IFNG is the most strongly associated with tryptophan catabolism through the kynurenine pathway, other ligands associate with metabolic pathways indicative of dysregulated central carbon metabolism, nitric oxide metabolism, and fatty acid oxidation. Altogether, these results indicate that 
medRxiv preprint doi: https://doi.org/10.1101/2021.07.29.21261325; this version posted August 1, 2021. The copyright holder for this preprint (which was not certified by peer review) is the author/funder, who has granted medRxiv a license to display the preprint in perpetuity.

It is made available under a CC-BY 4.0 International license .

modulation of IFN signaling in the clinic, either with agonists or antagonists, must take into account the endogenous state of the IFN ligand milieu, and that ligand-specific effects are to be expected.

\section{RESULTS}

Variable IFN signaling in COVID19 associates with levels of a specific subset of IFN ligands.

In this study, we analyzed the multi-omics datasets generated by the COVIDome Project

(covidome.org) to investigate IFN signaling in hospitalized COVID19 patients. The COVIDome Project datasets have been previously described $(16,17)$ and include matched analysis of whole blood transcriptome, plasma proteomics via complementary SOMAscan ${ }^{\circledR}$ assays and mass spectrometry, measurement of 82 immune factors by multiplexed immunoassays, SARS-CoV-2 seroconversion assays, immune cell profiling by mass cytometry, plasma and red blood cell metabolomics, as well as annotated clinical data. The COVIDome Project cohort analyzed in this study consists of 73 hospitalized COVID19 patients with mild-to-moderate disease versus 32 controls (see Supplementary file 1 for cohort characteristics and Methods). To monitor IFN signaling in this cohort, we first analyzed the transcriptome dataset. Using DESeq2 analysis, with adjustment for age and sex as covariates, we identified 2299 genes differentially expressed in the blood of COVID19 patients (Figure 1A, Supplementary file 2). Gene Set Enrichment Analysis (GSEA) identified the Hallmark Interferon Alpha and Gamma Response gene sets as the most significant positively enriched gene signatures in COVID19 patients (Figure 1B, Supplementary file 3). To assess inter-individual variation in expression of these IFN gene signatures, we calculated Z-score-based 'IFN Alpha' and 'IFN Gamma' transcriptional scores for each sample, showing that COVID19 patients show significantly increased yet highly variable IFN scores relative to controls (Figure 1C, Figure 1 - supplement 1A). In order to assess the degree to which this variability in IFN signaling was associated with the levels of circulating IFN ligands, we mined the SOMAscan ${ }^{\circledR}$ proteomics and multiplexed immunoassay datasets (Meso Scale Discovery assays, MSD, see Methods), which collectively measured a total of 17 different IFN ligands. To test the specificity of the reagents measured in these two platforms, we spiked single concentrations (SOMAscan ${ }^{\circledR}$ ) or multiple concentrations (MSD) of 16 of these IFN ligands, for which 
medRxiv preprint doi: https://doi.org/10.1101/2021.07.29.21261325; this version posted August 1, 2021. The copyright holder for this preprint (which was not certified by peer review) is the author/funder, who has granted medRxiv a license to display the preprint in perpetuity.

It is made available under a CC-BY 4.0 International license .

purified recombinant proteins were commercially available, into a pooled plasma reference sample (only IFNW1 could not be obtained, see Methods). This test led us to discard five SOMAscan ${ }^{\circledR}$ measurements (IFNA5, IFNA8, IFNA14, IFNA21, IFNL2) due to lack of sensitivity, and to relabel some measurements based on apparent cross-reactivity, such as IFNA4/16, IFN7/17/21, and IFNL3/2

(Figure 1 - supplement 1B). When the same IFN ligand was measured by both platforms, we preferred the MSD measurements, which are quantified against a standard curve (Figure 1 supplement 1C). This exercise allowed us to focus on measurements for 12 IFN ligands in our subsequent analyses: IFNA1, IFNA2, IFNA4/16, IFNA6, IFNA7/17/21, IFNA10, IFNA16, IFNB1, IFNG, IFNL1, INFL3/2, and IFNW1 (Figure 1 - supplement 1B-D). We next determined Spearman correlations between the RNA-based IFN Alpha transcriptional scores and levels of the 12 IFN ligands (Figure 1D). Interestingly, the correlations were highly variable, and four of the ligands did not show significant associations with the IFN Alpha transcriptional scores (IFNB1, IFNA16, IFNW1, and IFNA6). This result is clearly illustrated by the Type I ligands IFNA2 and IFNA6, which are the most and least correlated with IFN Alpha scores, respectively. Although both ligands are significantly upregulated in the plasma of COVID19 patients (Figure 1E), only IFNA2 levels correlate with the IFN Alpha scores (Figure 1F) and with expression of well recognized ISGs, such as ISG15 and OAS2 (Figure 1F-G). These differences could not be simply explained by the degree of induction of the various ligands in COVID19 patients, as illustrated by IFNA7/17/21, IFNL3/2, IFNA10 and IFNL1, all of which were not statistically higher among COVID19 patients (Figure 1 - supplement 1D) but nonetheless correlated significantly with IFN Alpha scores (Figure 1D). Repeating this analysis for IFN Gamma scores produced a very similar rank of correlations, which is perhaps not surprising given the high overlap between the IFN Alpha and Gamma Response Hallmark GSEA gene sets (18) (Figure 1 -

\section{supplement $1 \mathrm{~A}$, see Methods).}

To explore this phenomenon more deeply, we completed a comprehensive analysis of gene expression signatures in the whole blood transcriptome associated with varying plasma levels of the 12 IFN ligands, using only data from COVID19 patients. Toward this end, we defined Spearman correlations between each ligand and mRNAs for 15,000+ genes detected by RNAseq, which identified thousands 
medRxiv preprint doi: https://doi.org/10.1101/2021.07.29.21261325; this version posted August 1, 2021. The copyright holder for this preprint (which was not certified by peer review) is the author/funder, who has granted medRxiv a license to display the preprint in perpetuity.

It is made available under a CC-BY 4.0 International license .

of significant positive and negative correlations, with great variability across ligands (Figure 1 -

supplement 2A, Supplementary file 4). We then analyzed the ranked correlations for each IFN ligand using GSEA to identify known gene sets with significant enrichment among positive or negative correlations with the levels of each ligand (Figure $1 \mathrm{H}$, Supplementary file 5). This analysis showed that the top gene signatures positively associated with 8 of the IFN ligands are indeed the IFN Alpha and Gamma Responses, followed by related inflammatory and immune pathways (e.g. TNFA signaling, Inflammatory response, IL6/JAK/STAT3 signaling). In contrast, for the other 4 ligands (IFNB1, IFNA6, IFNW1, and IFNA16), the top signatures enriched in the positive correlations are related to cell proliferation, such as G2M checkpoint, E2F targets, and MYC targets (Figure 1H). In fact, some of these ligands show negative correlations with the IFN Alpha and Gamma Responses (Figure 1H). This result is once again illustrated by the differential behavior of IFNA2 and IFNA6. Whereas mRNAs positively associated with IFNA2 show clear enrichment of the IFN Alpha Response gene set, these same mRNAs are negatively correlated with IFNA6 levels (e.g. ISG15, Figure 1 - supplement 2B). Altogether, these results suggest functional specialization among circulating IFN ligands, whereby only a fraction of ligands associates with the recognizable IFN transcriptional response in circulating immune cells. 
medRxiv preprint doi: https://doi.org/10.1101/2021.07.29.21261325; this version posted August 1, 2021. The copyright holder for this preprint (which was not certified by peer review) is the author/funder, who has granted medRxiv a license to display the preprint in perpetuity.

It is made available under a CC-BY 4.0 International license.

A

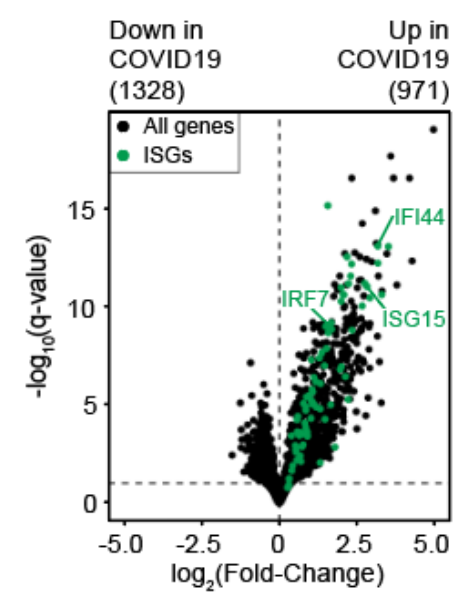

B

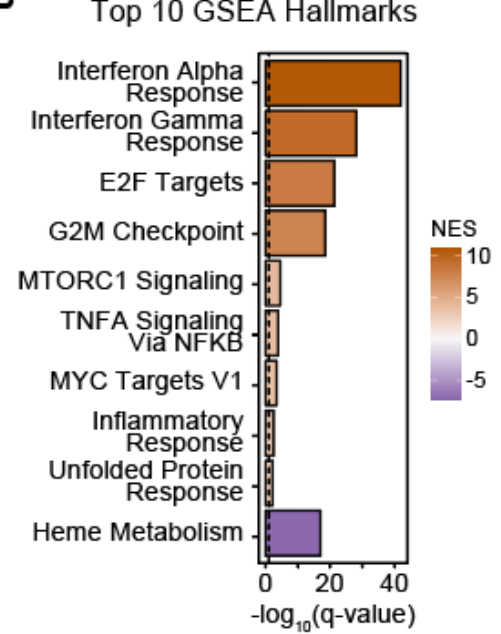

C

IFN Alpha scores RNA (51 genes)

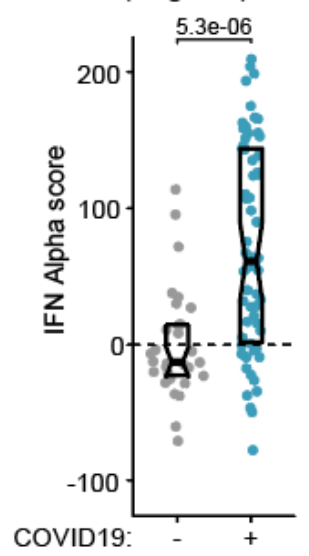

Figure 1

$\mathrm{H}$
E

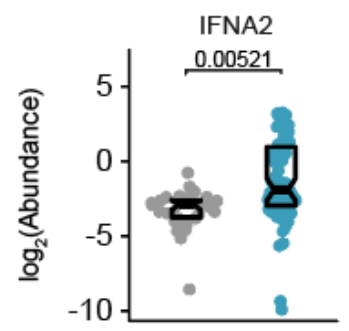

CoVID19:

$\mathbf{F}$

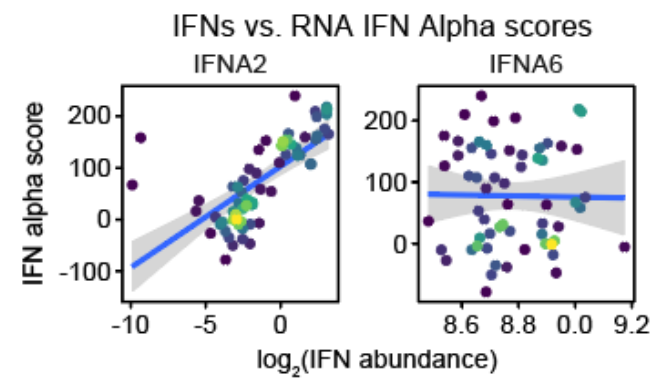

G

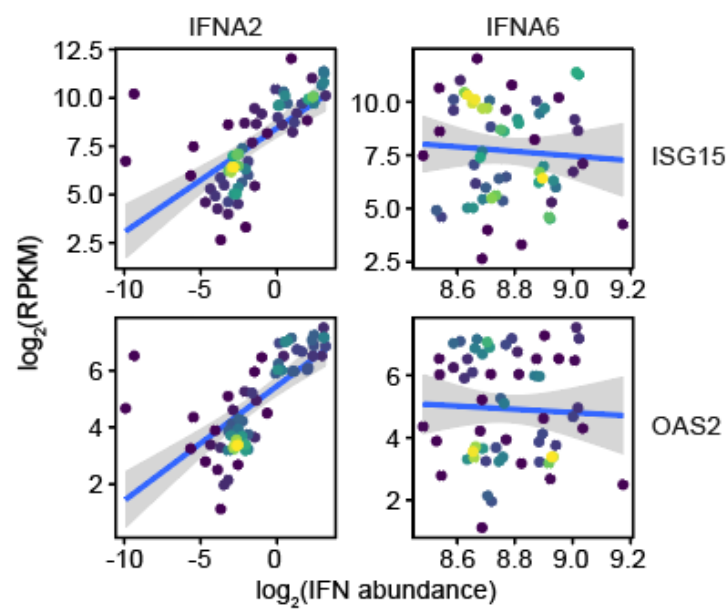

$\begin{array}{lll}50 & 150 \quad 250\end{array}$
IFNA6

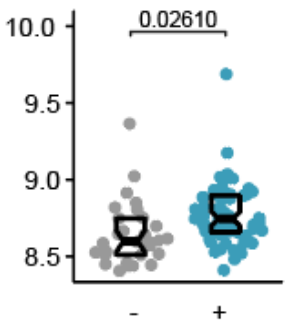

IFNs vs. ISG mRNAs

$$
\text { Density }
$$

GSEA: IFNs vs. transcriptome correlations

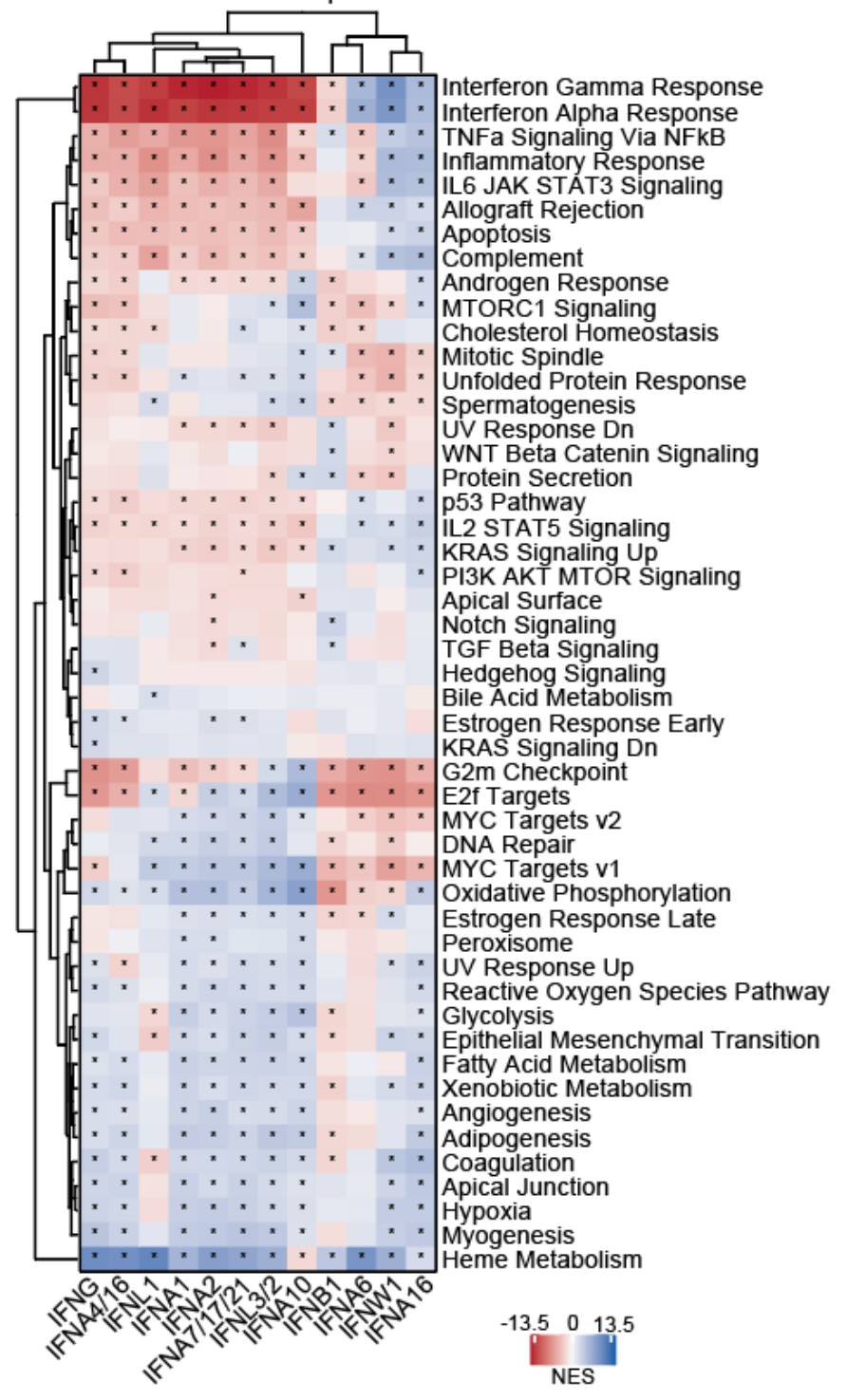


medRxiv preprint doi: https://doi.org/10.1101/2021.07.29.21261325; this version posted August 1, 2021. The copyright holder for this preprint (which was not certified by peer review) is the author/funder, who has granted medRxiv a license to display the preprint in perpetuity.

It is made available under a CC-BY 4.0 International license.

Figure 1. IFN signaling at the whole-blood transcriptome level correlates with a subset of IFN ligands. (A) Volcano plot for DESeq2 differential expression analysis of gene-level count data for COVID19-positive vs. -negative samples, adjusted for age and sex. Horizontal dashed line indicates an FDR threshold of $10 \%$ for negative binomial Wald test; numbers above plot indicate significant genes at this threshold. Interferon stimulated genes (ISGs) are highlighted in green. (B) Bar plot of top 10 Hallmark gene sets as ranked by absolute normalized enrichment score (NES) from Gene Set Enrichment Analysis (GSEA). Bar color represents NES; Bar length represents - $\log _{10}(\mathrm{FDR}$ q-value). (C) RNA-based IFN Alpha scores, separated by COVID19 status. Scores were calculated for each research participant by summing Z-scores for 51 differentially expressed genes from the Interferon Alpha Response Hallmark gene set from MSigDB. Z-scores were calculated from the adjusted concentration values for each gene in each sample, based on the mean and standard deviation of COVID19-negative samples. Data are presented as a modified sina plot with box indicating median and interquartile range. (D) Ranked heatmap representing correlations between RNA-based IFN Alpha scores and plasma levels of each IFN ligand. Values displayed are Spearman correlation coefficients (Rho); asterisks indicate significant correlations (10\% FDR). (E) Sina plots comparing abundance for the indicated IFNs in COVID19-negative (-) vs. -positive (+) plasma samples. Data are presented as modified sina plots with boxes indicating median and interquartile range. Numbers above brackets are q-values for Mann-Whitney tests. (F) Scatter plots showing the relationship between RNA-based IFN Alpha score and plasma abundance of the indicated IFNs in COVID19-positive patients. Points are colored by density; blue lines represent linear model fit with $95 \%$ confidence intervals in grey. (G) Scatter plots showing the relationship between ISG mRNA levels and plasma abundance of the indicated IFNs in COVID19-positive patients. Points are colored by density; blue lines represent linear model fit with 95\% confidence intervals in grey. $(\mathbf{H})$ Heatmap representing enrichment of Hallmark gene sets among Spearman correlations between mRNA levels and plasma levels of each IFN ligand. Values displayed are NES from GSEA; asterisks indicate significant enrichment (10\% FDR); columns and rows are grouped by hierarchical clustering. See also Figure 1 - supplement 1 and Figure 1 supplement 2. 
medRxiv preprint doi: https://doi.org/10.1101/2021.07.29.21261325; this version posted August 1, 2021. The copyright holder for this preprint (which was not certified by peer review) is the author/funder, who has granted medRxiv a license to display the preprint in perpetuity.

It is made available under a CC-BY 4.0 International license .

Figure 1 - supplement 1

A

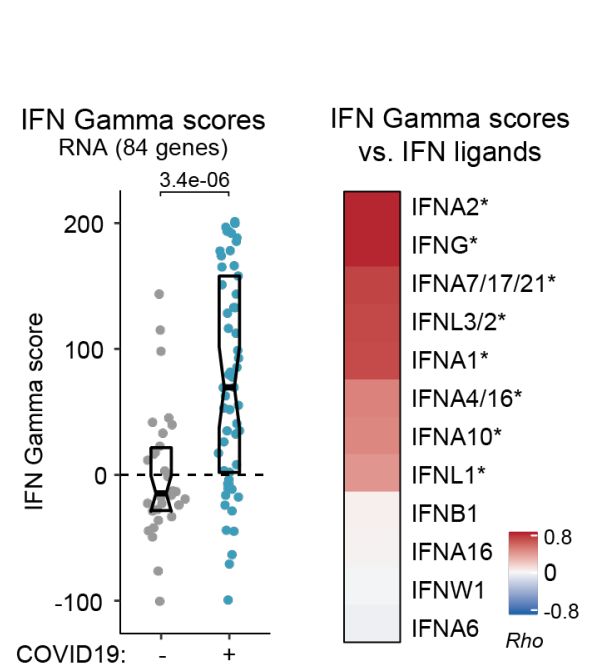

C

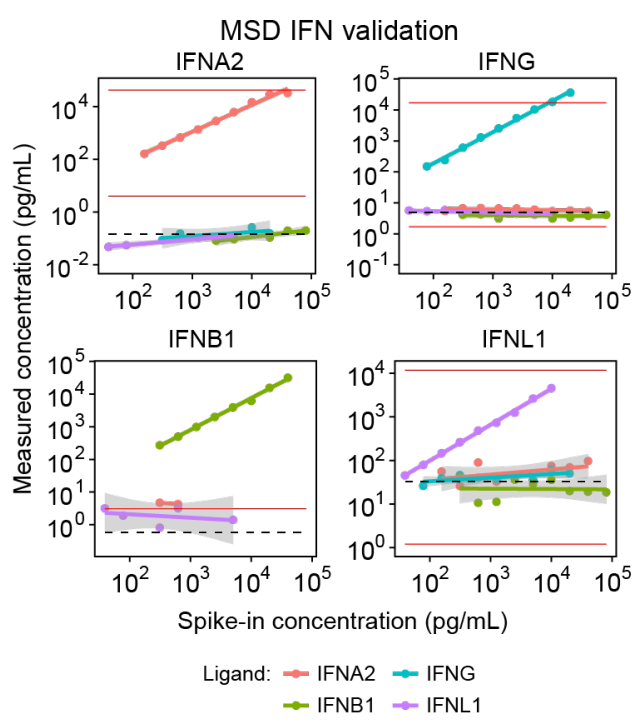

B

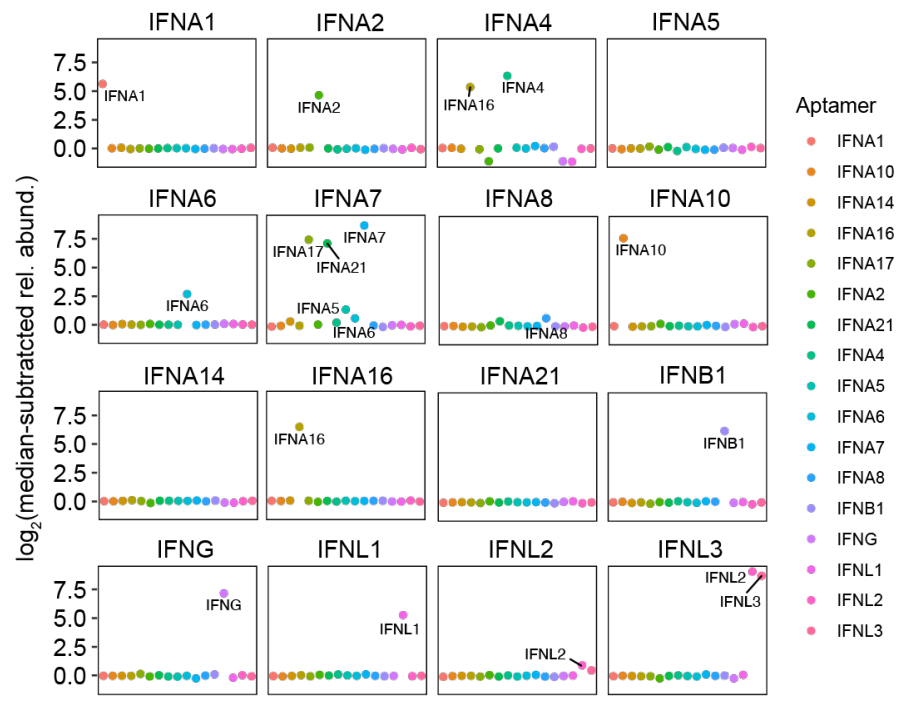

D

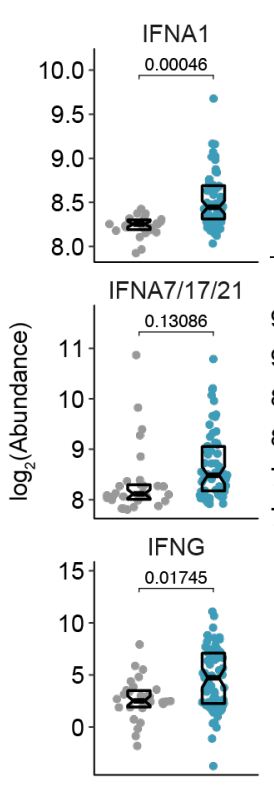

Figure 1 - supplement 1. Whole-blood RNA-based IFN Gamma scores and validation of plasma IFN ligand measurements. (A) Sina plot of RNA-based IFN Gamma scores, separated by COVID19 status and ranked heatmap representing correlations between RNA-based IFN Gamma scores and plasma levels of each IFN ligand. IFN Gamma scores were calculated for each research participant by summing Z-scores for 84 differentially expressed genes from the IFN Gamma response Hallmark gene set from MSigDB. Z-scores were calculated from the adjusted concentration values for each gene in each sample, based on the mean and standard deviation of COVID19-negative samples. Data are presented as a modified sina plot with box indicating median and interquartile range. Heatmap values displayed are Spearman correlation coefficients (Rho); asterisks indicate significant correlations $(10 \%$ FDR). (B) Validation of IFN ligand detection by SOMAscan ${ }^{\circledR}$ assay. Each plot represents relative abundance above background measured by IFN-targeting SOMAscan ${ }^{\circledR}$ aptamers (indicated by color) for each recombinant IFN ligand spike-in (indicated by plot labels). (C) Validation of IFN ligand detection by MSD immunoassay. Plots show the relationship between measured concentration and spike-in concentration for each recombinant IFN ligand (indicated by point and line color) for each 
medRxiv preprint doi: https://doi.org/10.1101/2021.07.29.21261325; this version posted August 1, 2021. The copyright holder for this preprint (which was not certified by peer review) is the author/funder, who has granted medRxiv a license to display the preprint in perpetuity.

It is made available under a CC-BY 4.0 International license.

assay (indicated by plot labels). Horizontal dashed lines indicate measured concentrations for the pooled plasma sample with no spike-in; red lines indicate manufacturer-stated detection limits. (D) Sina plots comparing abundance for the indicated IFNs in COVID19-negative (-) vs. -positive (+) plasma samples. Data are presented as modified sina plots with boxes indicating median and interquartile range. Numbers above brackets are q-values for Mann-Whitney tests. 
medRxiv preprint doi: https://doi.org/10.1101/2021.07.29.21261325; this version posted August 1, 2021. The copyright holder for this preprint (which was not certified by peer review) is the author/funder, who has granted medRxiv a license to display the preprint in perpetuity.

It is made available under a CC-BY 4.0 International license.

A
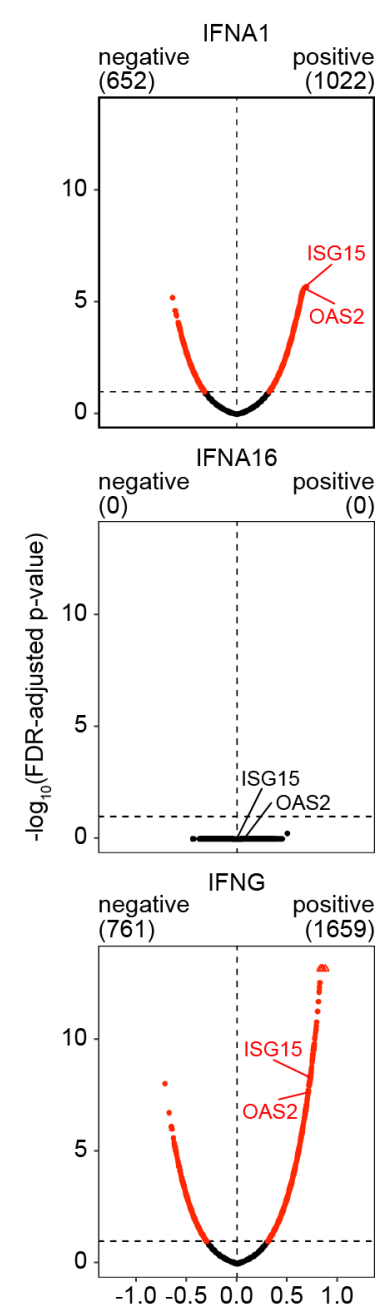

Correlations: IFN ligands vs. Transcriptome

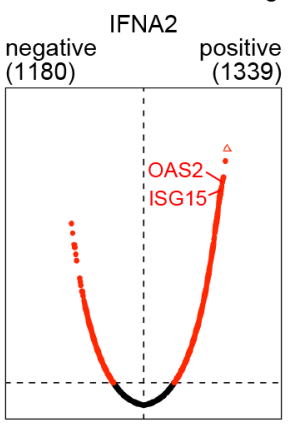

IFNA4/16
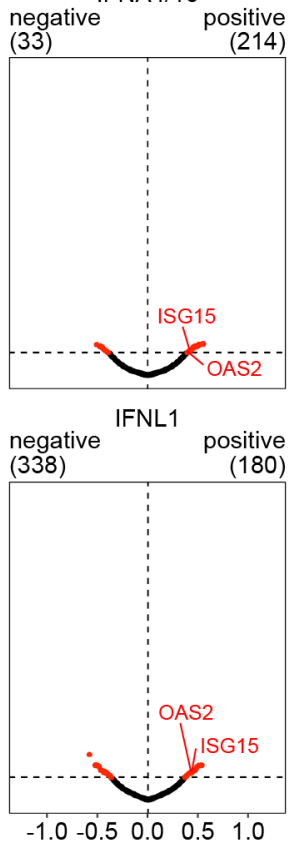

Spearman rho

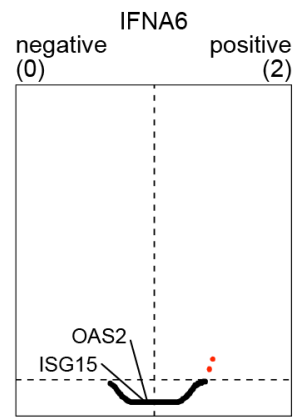

IFNA7/17/21
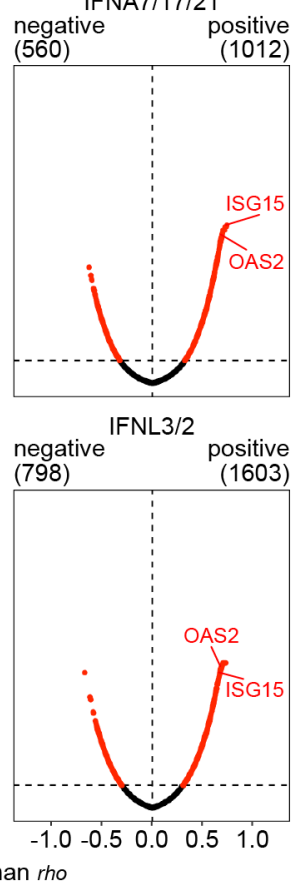

Figure 1 - supplement 2

B
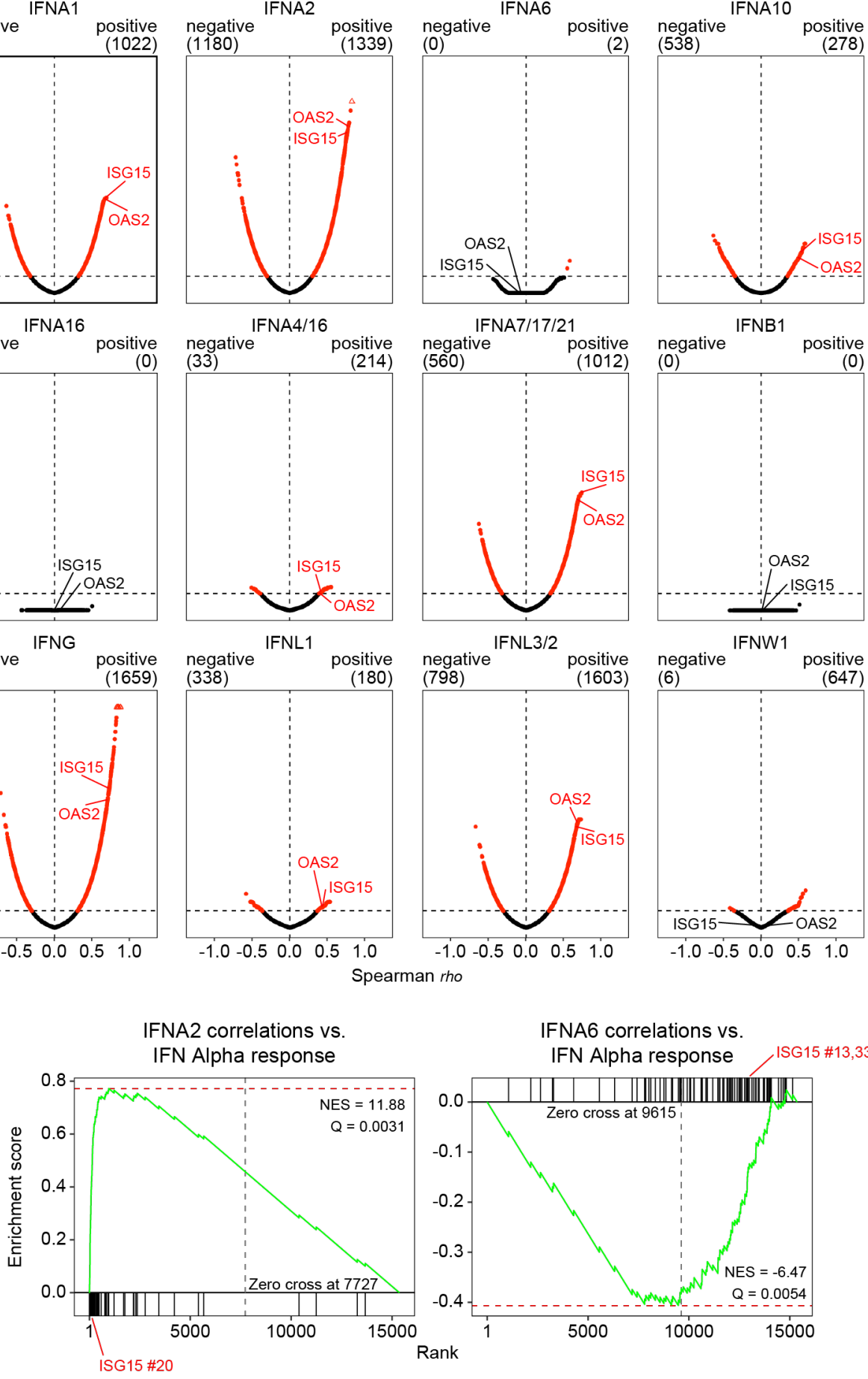

IFNB1
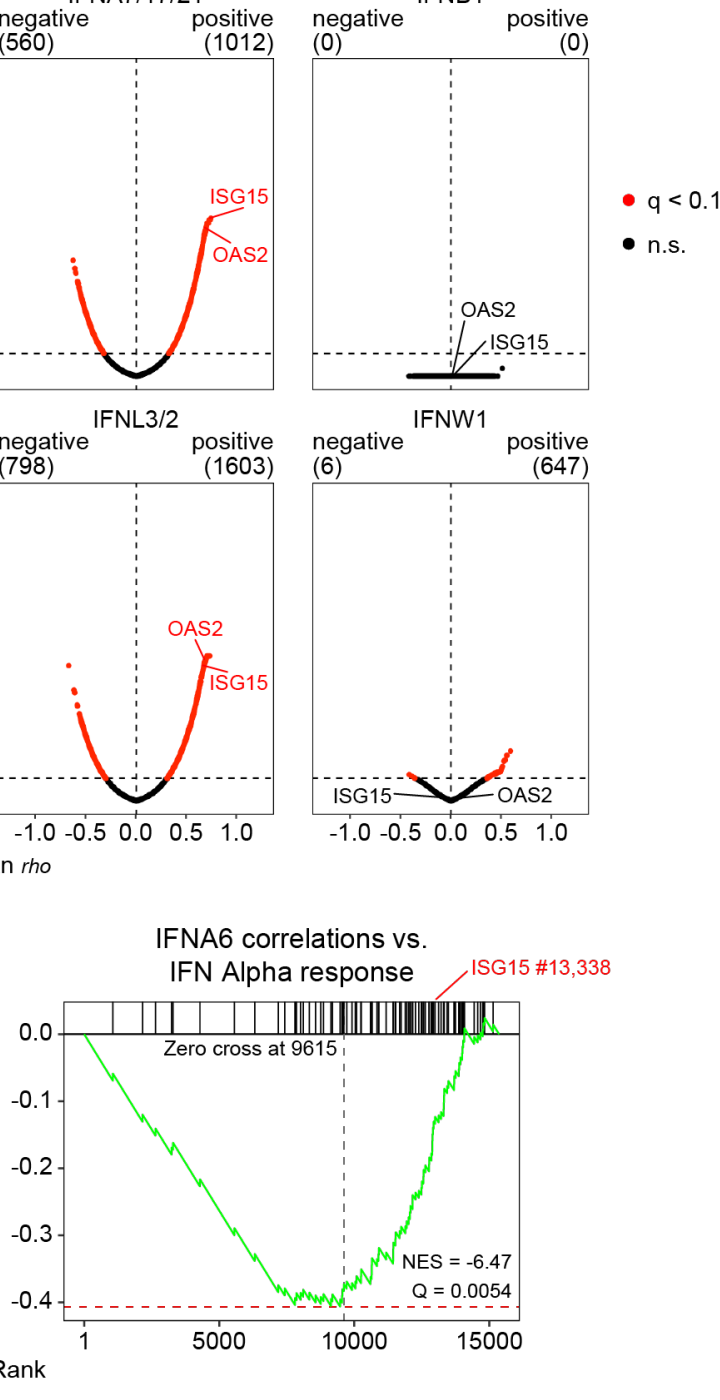

Figure 1 - supplement 2. Correlation analysis and GSEA for IFN ligands vs. whole blood transcriptome. (A) Volcano plots for Spearman correlation analysis of IFN ligands vs. gene-level RPKM values. Horizontal dashed line indicates an FDR threshold of $10 \%(q<0.1)$; red points and numbers above plots indicate significant genes at this threshold. (B) Gene set enrichment analysis (GSEA) plots for the IFN Alpha Response Hallmark gene set from MSigDB. Green lines indicate cumulative enrichment score; black bars indicate gene set hits among all genes ranked by log2(fold change) for COVID19-positive vs. -negative samples. 
medRxiv preprint doi: https://doi.org/10.1101/2021.07.29.21261325; this version posted August 1, 2021. The copyright holder for this preprint (which was not certified by peer review) is the author/funder, who has granted medRxiv a license to display the preprint in perpetuity.

It is made available under a CC-BY 4.0 International license .

\section{IFN ligands show differential proteomic signatures associated to COVID19 pathophysiology.}

Next, we investigated the proteomic signatures associated with each ligand. Using a linear model adjusting for age and sex, we identified 963 epitopes measured by the SOMAscan ${ }^{\circledR}$ platform differentially abundant in the plasma of COVID19 patients (Figure 2A, Supplementary file 6). GSEA identified Hallmark IFN Alpha and Gamma Responses as the top proteomic signatures induced in COVID19 (Figure 2B, Supplementary file 7). As for the transcriptome, we created protein-based IFN alpha and gamma scores for each participant, which showed significantly higher yet highly variables IFN scores among COVID19 patients (Figure 2C, Figure 2 - supplement 1A). Notably, plasma protein-based IFN scores may inform about the organismal IFN response, not just that of circulating immune cells driving the whole blood transcriptome IFN signature, as multiple organs and tissues could contribute to secretion of IFN-related proteins. We then defined correlations between the 12 ligands and the protein-based IFN scores, which revealed some similarities and differences relative to the RNA-based IFN scores (Figure 2D). Whereas IFNA2 and IFNG remained as the ligands most correlated with the protein-based IFN Alpha and Gamma scores, other ligands behaved differently (Figure 2D, Figure 2 - supplement 1A). For example, IFNA10, which was significantly correlated with the RNA-based IFN Alpha and Gamma scores, was not so with the protein-based IFN Alpha and Gamma scores. In contrast, IFNA6 and IFNB1 ranked higher in their association with the protein-based scores (Figure 1D, Figure 2D, Figure 2 - supplement 1A). As for the transcriptome analysis, we then defined Spearman correlations between each of the 12 ligands and 4800+ epitopes measured by SOMAscan $^{\circledR}$ proteomics and analyzed the correlation results with GSEA (Figure 2 - supplement 1B, Figure 2E, Supplementary file 8, Supplementary file 9). Interestingly, some IFN ligands with weak transcriptome signatures nonetheless present strong proteomic signatures. For example, IFNA6 and IFNB1, which show very weak correlations with mRNAs (Figure 1 - supplement 2A), are among the ligands with the most numerous significant associations with circulating proteins (Figure 2 supplement 1B). In fact, unsupervised hierarchical clustering of the proteomic GSEA signatures placed IFNA6 and IFNB1 together with IFNA2 and IFNG (Figure 2E). This suggest that whereas IFNA6 and IFNB1 may not contribute to the IFN transcriptional response of circulating immune cells, they may 
medRxiv preprint doi: https://doi.org/10.1101/2021.07.29.21261325; this version posted August 1, 2021. The copyright holder for this preprint (which was not certified by peer review) is the author/funder, who has granted medRxiv a license to display the preprint in perpetuity.

It is made available under a CC-BY 4.0 International license .

nonetheless contribute to IFN responses in peripheral tissues and organs contributing to the proteinbased plasma IFN signature. This is illustrated by the behavior of CXCL11 (IFN-inducible protein 9), a canonical ISG, which is significantly correlated at the protein level with IFNA2, IFNA6 and IFNB1

(Figure 2 - supplement 2A). Additionally, IFN ligands often display highly dissimilar, even opposite, relationships to certain proteomics signatures. This is clearly illustrated by the PI3K/AKT/mTOR signature, which was positively correlated with some ligands and negatively correlated with others (Figure 2E, compare correlations to HRAS for IFNA1, IFNA6 and IFNB1 in Figure 2 - supplement 2B).

To probe further into this phenomenon, we examined the top 5 positively and negatively correlated epitopes for each ligand using unsupervised clustering analysis, which revealed many specialized relationships with potential relevance to COVID19 pathophysiology (Figure 2 - supplement 2C). For example, several chemokines involved in immune control showed differential associations, such as CXCL10 (IP10, compare IFNG to IFNW1 in Figure 2F); CX3CL1 (fractalkine, compare IFNA10 to IFNA6 in Figure 2G); CCL7 (MCP3, compare IFNA2 to IFNA16 in Figure 2 - supplement 2D); and CCL5 (RANTES, compare IFNB1 to IFNA10 in Figure 2 - supplement 2E). Notably, the top positive correlations for IFNB1 are dominated by proteins stored in alpha granules of platelets, such as PPBP (multiple SOMAscan ${ }^{\circledR}$ aptamers), PDGFA, PDGFD, and PF4 (Figure 2 - supplement 2C,

Supplementary file 8). These markers of platelet degranulation are also associated, albeit to a lesser degree, with IFNA6, but not so with other ligands (Figure 2 - supplement 2C, compare IFNB1 to IFNA10 in Figure 2H). This suggests that IFNB1 production is associated with platelet activation, which could be interpreted as a sign of endothelial damage at sites producing IFNB1. A subset of IFN ligands showed strong associations with components of the complement cascade, such as C1QC (Figure 2 supplement 2C, compare IFNA2 to IFNB1 in Figure 2I). The top correlated epitope for IFNA10 is TRIL (TRL4 interactor with leucine-rich repeats), a component of the TLR4 complex, but this association was not clear for many other IFN ligands (Figure 2 - supplement 2C, compare IFNA10 to IFNA6 in Figure 2 - supplement 2F). KIR3DL2 and KIR3DS1, two killer cell immunoglobulin-like receptors (KIRs) expressed by Natural Killer (NK) cells and subtypes of T cells were strongly correlated with a subset of 
medRxiv preprint doi: https://doi.org/10.1101/2021.07.29.21261325; this version posted August 1, 2021. The copyright holder for this preprint (which was not certified by peer review) is the author/funder, who has granted medRxiv a license to display the preprint in perpetuity.

It is made available under a CC-BY 4.0 International license .

ligands, most prominently IFNA6, but not others (Figure 2 - supplement $2 \mathrm{C}$, compare IFNA6 to

IFNA10 in Figure 2 - supplement 2G). OLFM4 (Olfactomedin 4), a protein selectively expressed in

inflamed colonic epithelium (19), was strongly associated with IFNA4/16, but not other ligands (Figure

2 - supplement 2C, compare IFNA4/16 versus IFNA10 in Figure 2 - supplement 2H).

Altogether, these results reveal that circulating levels of different IFN ligands associate with proteomics signatures indicative of multiple pathophysiological processes, such as tissue-specific inflammation, complement activation, and endothelial damage. 
medRxiv preprint doi: https://doi.org/10.1101/2021.07.29.21261325; this version posted August 1, 2021. The copyright holder for this preprint (which was not certified by peer review) is the author/funder, who has granted medRxiv a license to display the preprint in perpetuity.

It is made available under a CC-BY 4.0 International license .

A Plasma proteins (SOMAscan)

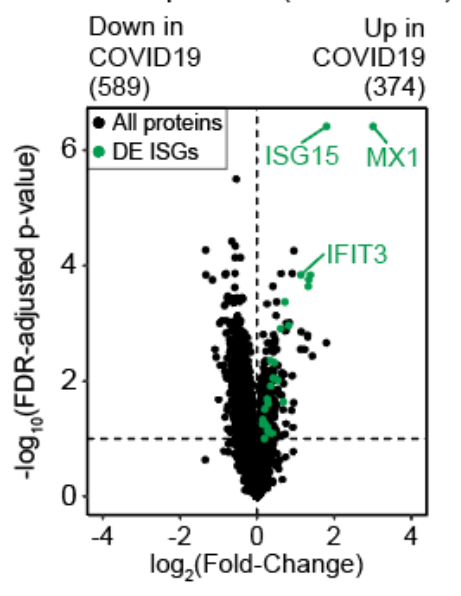

E

GSEA: IFNs vs. SOMAscan correlations

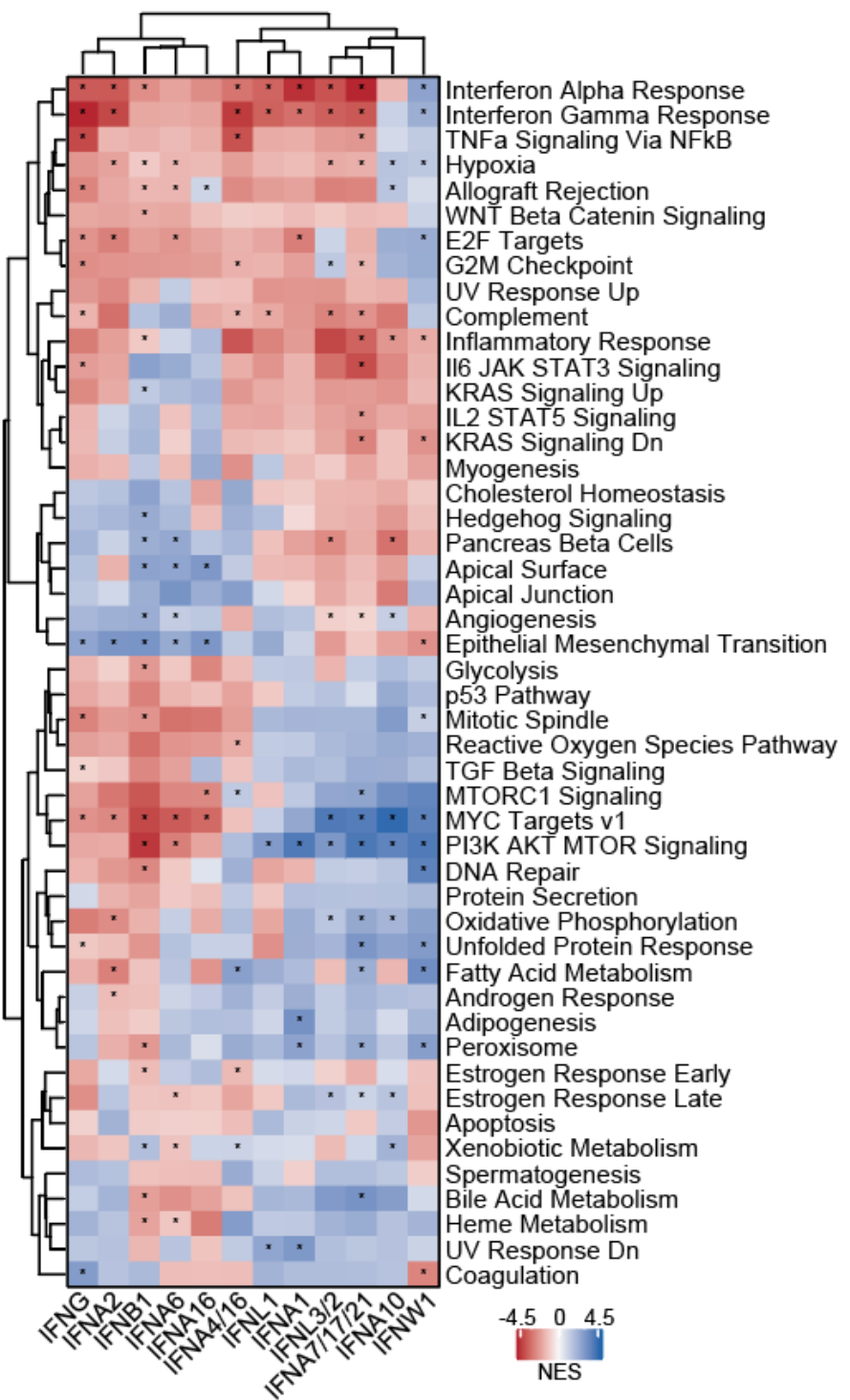

B Top 10 GSEA Hallmarks

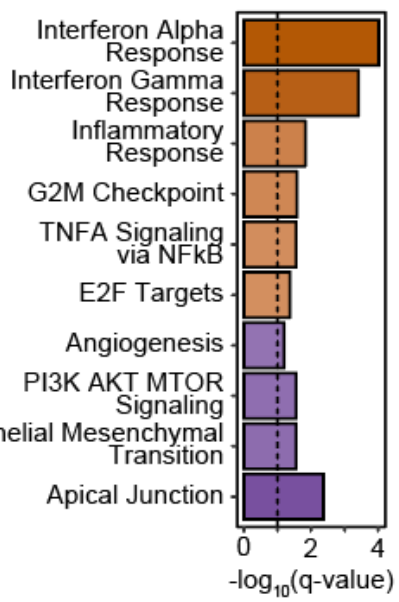

$\mathbf{F}$
C IFN Alpha scores SOMAscan (14 proteins)

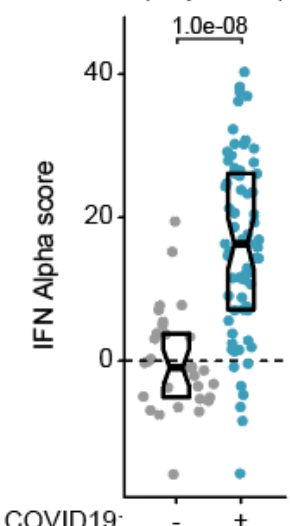

Figure 2

D IFN Alpha scores vs. IFN ligands

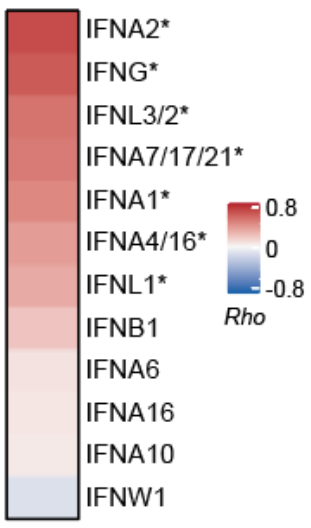

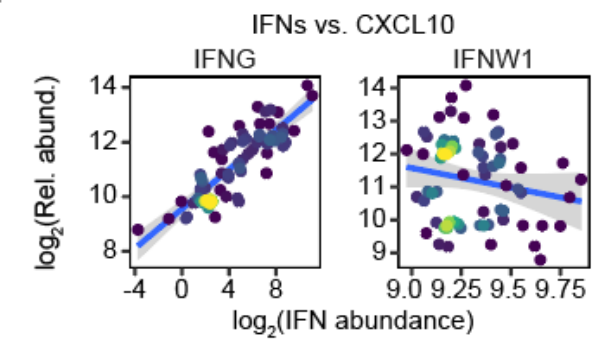

G

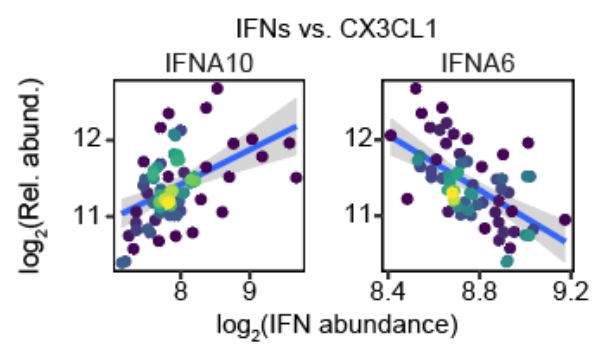

H
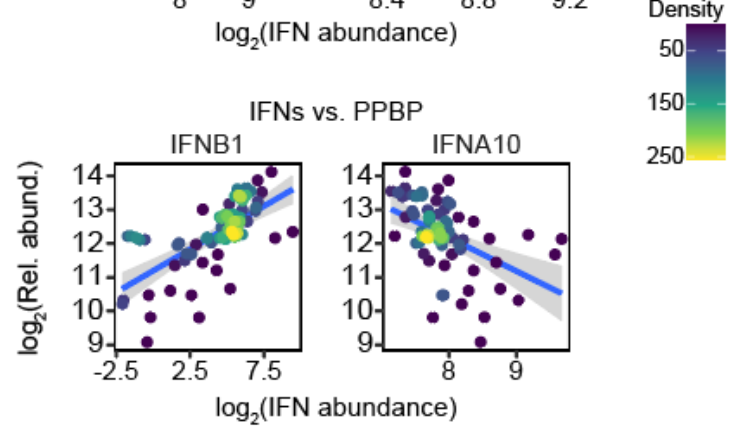

I

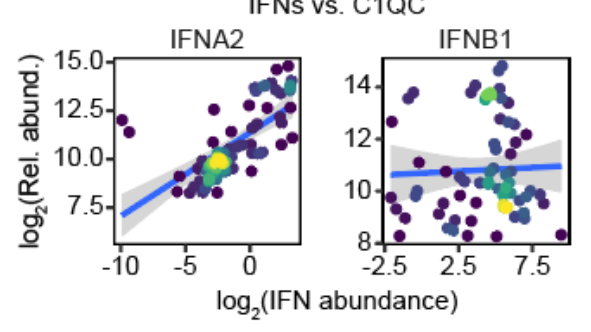

Figure 2. IFN signaling at the proteome level correlates with features of COVID19 pathophysiology. (A) Volcano plot for linear regression analysis of Somascan plasma protein 
medRxiv preprint doi: https://doi.org/10.1101/2021.07.29.21261325; this version posted August 1, 2021. The copyright holder for this preprint (which was not certified by peer review) is the author/funder, who has granted medRxiv a license to display the preprint in perpetuity.

It is made available under a CC-BY 4.0 International license .

abundance data for COVID19-positive vs. -negative samples, adjusted for age and sex. Horizontal dashed line indicates an FDR threshold of $10 \%(q<0.1)$; numbers above plot indicate significant genes at this threshold. Proteins encoded by Interferon Stimulated Genes (ISGs) are highlighted in green. (B) Barplot of top 10 Hallmark gene sets as ranked by absolute normalized enrichment score (NES) from Gene Set Enrichment Analysis (GSEA). Bar color represents NES; Bar length represents - $\log _{10}$ (FDR qvalue). (C) Protein-based IFN Alpha scores, separated by COVID19 status. Scores were calculated for each research participant by summing Z-scores for 14 differentially abundant proteins from the Interferon Alpha Response Hallmark gene set from MSigDB. Z-scores were calculated from the adjusted concentration values for each gene in each sample, based on the mean and standard deviation of COVID19-negative samples. Data are presented as a modified sina plot with box indicating median and interquartile range. (D) Ranked heatmap representing correlations between protein-based IFN Alpha scores and plasma levels of each IFN ligand. Values displayed are Spearman correlation coefficients (Rho); asterisks indicate significant correlations (10\% FDR). (E) Heatmap representing enrichment of Hallmark gene sets among Spearman correlations between plasma levels of proteins measured by SOMAscan and each IFN ligand. Only proteins with at least one significant correlation are shown. Values displayed are NES from GSEA; asterisks indicate significant enrichment (10\% FDR); columns and rows are grouped by hierarchical clustering. (F-I) Scatter plots comparing relationships between plasma proteins and the indicated IFNs in COVID19-positive patients. Points are colored by density; blue lines represent linear model fit with 95\% confidence intervals in grey. See also Figure 2 supplement 1 and Figure 2 - supplement 2. 
medRxiv preprint doi: https://doi.org/10.1101/2021.07.29.21261325; this version posted August 1, 2021. The copyright holder for this preprint (which was not certified by peer review) is the author/funder, who has granted medRxiv a license to display the preprint in perpetuity.

It is made available under a CC-BY 4.0 International license .

A

IFN Gamma scores

SOMAscan (23 proteins)

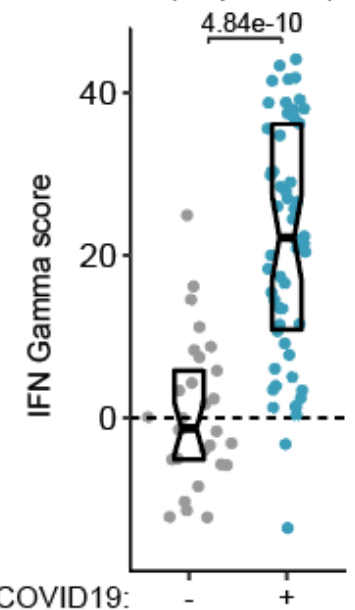

IFN Gamma scores

vs. IFN ligands

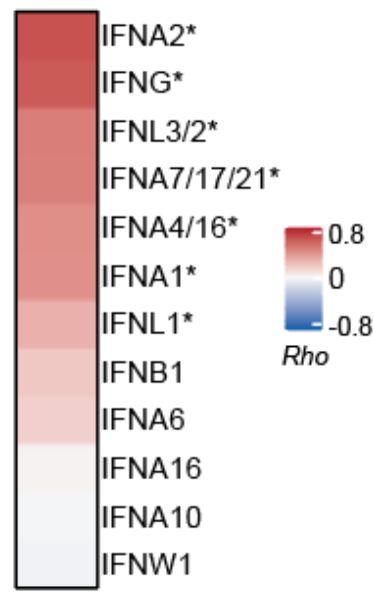

Figure 2 - supplement 1

B

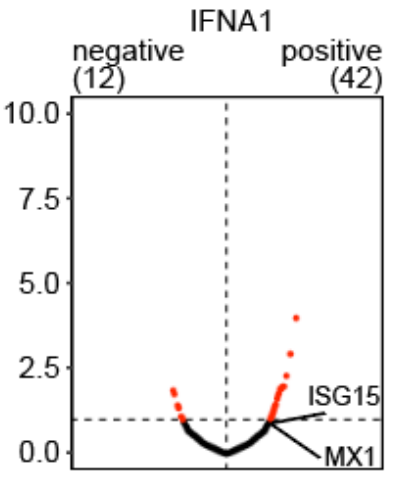

IFNA16
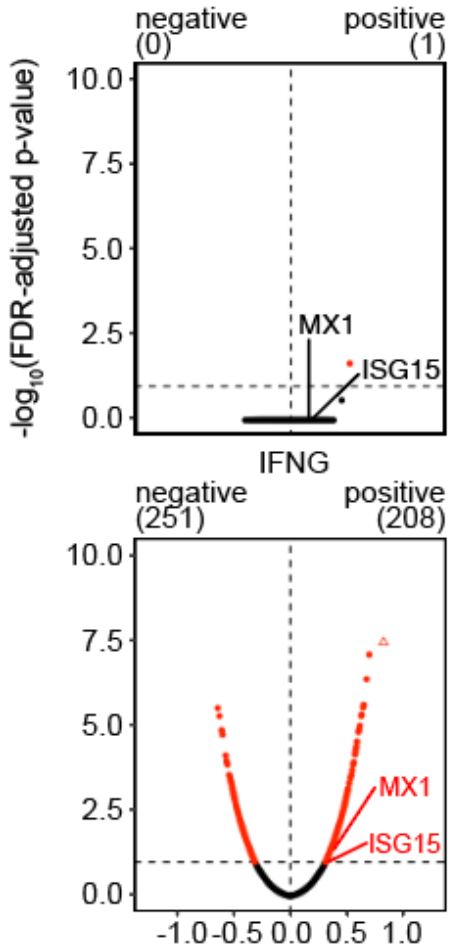

Correlations: IFN ligands vs. SOMAscan Proteomics

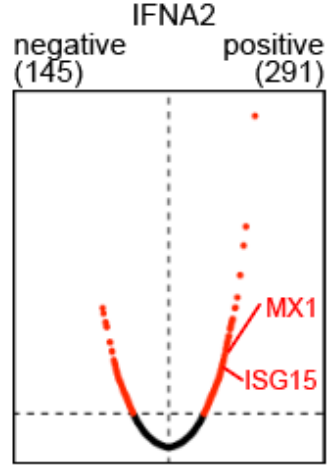

IFNA4/16

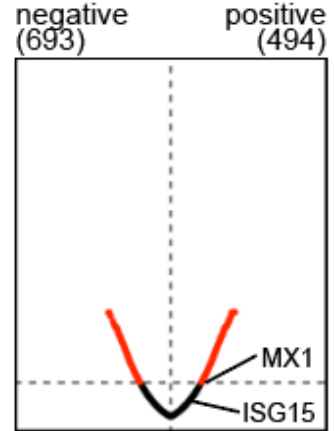

IFNL1
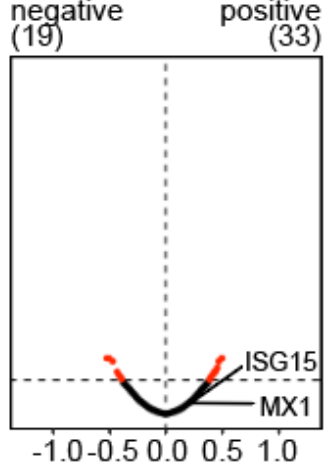

IFNA6

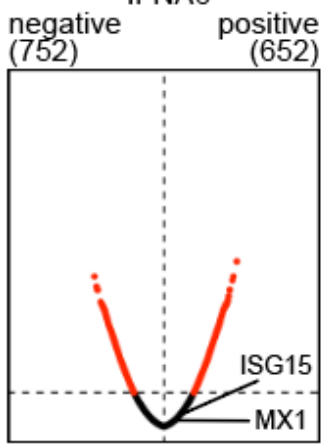

IFNA7/17/21

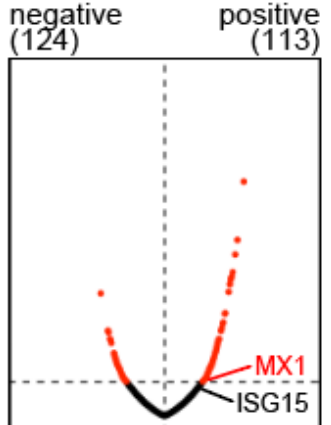

IFNL3/2

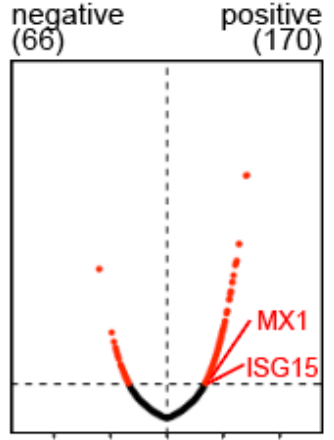

$-1.0-0.50 .00 .51 .0$

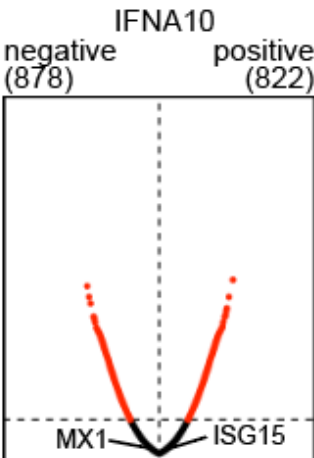

IFNB1

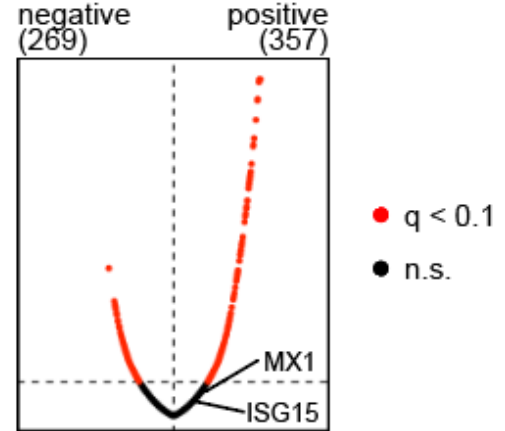


medRxiv preprint doi: https://doi.org/10.1101/2021.07.29.21261325; this version posted August 1, 2021. The copyright holder for this preprint (which was not certified by peer review) is the author/funder, who has granted medRxiv a license to display the preprint in perpetuity.

It is made available under a CC-BY 4.0 International license .

Figure 2 - supplement 1. Plasma protein-based IFN Gamma scores and correlation analysis for IFN ligands vs. SOMAscan ${ }^{\circledR}$ proteomics. (A) Sina plot of protein-based IFN Gamma scores, separated by COVID19 status and ranked heatmap representing correlations between protein-based IFN Gamma scores and plasma levels of each IFN ligand. IFN gamma scores were calculated for each research participant by summing Z-scores for 23 differentially abundant proteins from the IFN Gamma Response Hallmark gene set from MSigDB. Z-scores were calculated from the adjusted concentration values for each gene in each sample, based on the mean and standard deviation of COVID19-negative samples. Data are presented as a modified sina plot with box indicating median and interquartile range. Heatmap values displayed are Spearman correlation coefficients (Rho); asterisks indicate significant correlations (10\% FDR). (B) Volcano plots for Spearman correlation analysis of IFN ligands vs.

Somascan protein abundance values. Horizontal dashed line indicates an FDR threshold of 10\% (q< 0.1 ); red points and numbers above plots indicate significant proteins at this threshold. 
medRxiv preprint doi: https://doi.org/10.1101/2021.07.29.21261325; this version posted August 1, 2021. The copyright holder for this preprint (which was not certified by peer review) is the author/funder, who has granted medRxiv a license to display the preprint in perpetuity.

It is made available under a CC-BY 4.0 International license .

A

B

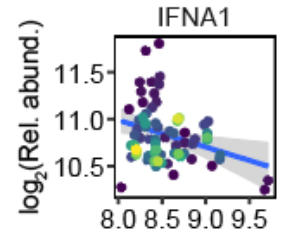

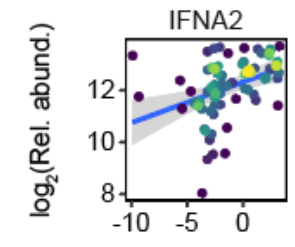

IFNs vs. CXCL11

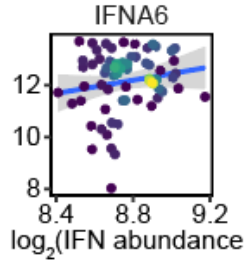

IFNs vs. HRAS
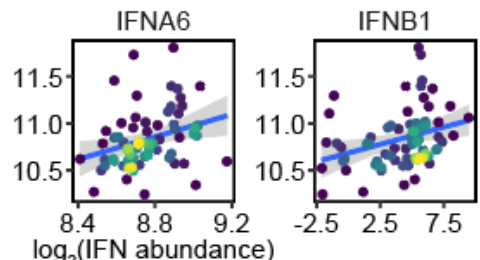

IFNs vs. CCL7

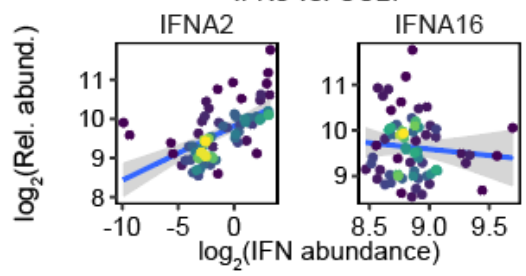

E

IFNs vs. CCL5
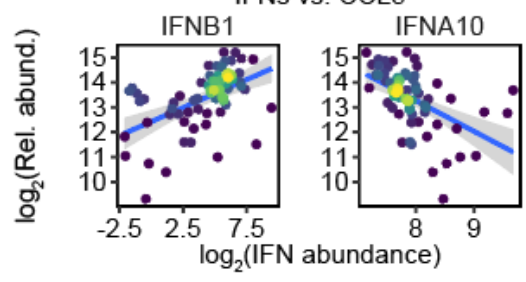

$\mathbf{F}$

IFNs vs. TRIL
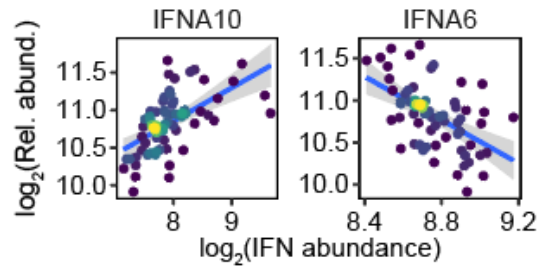

G

IFNs vs. KIR3DL2
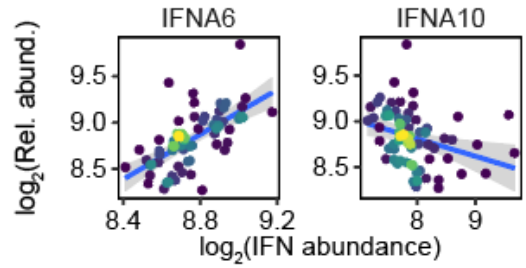

H
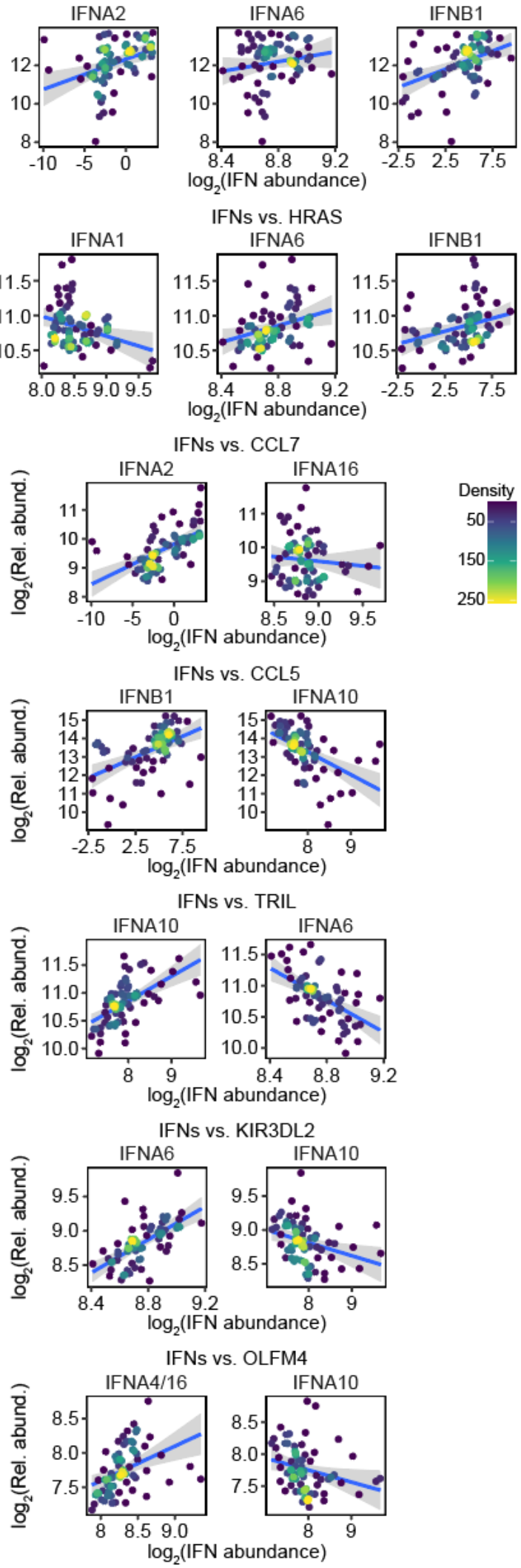

C

IFNs vs. SOMAscan correlations

Figure 2 - supplement 2

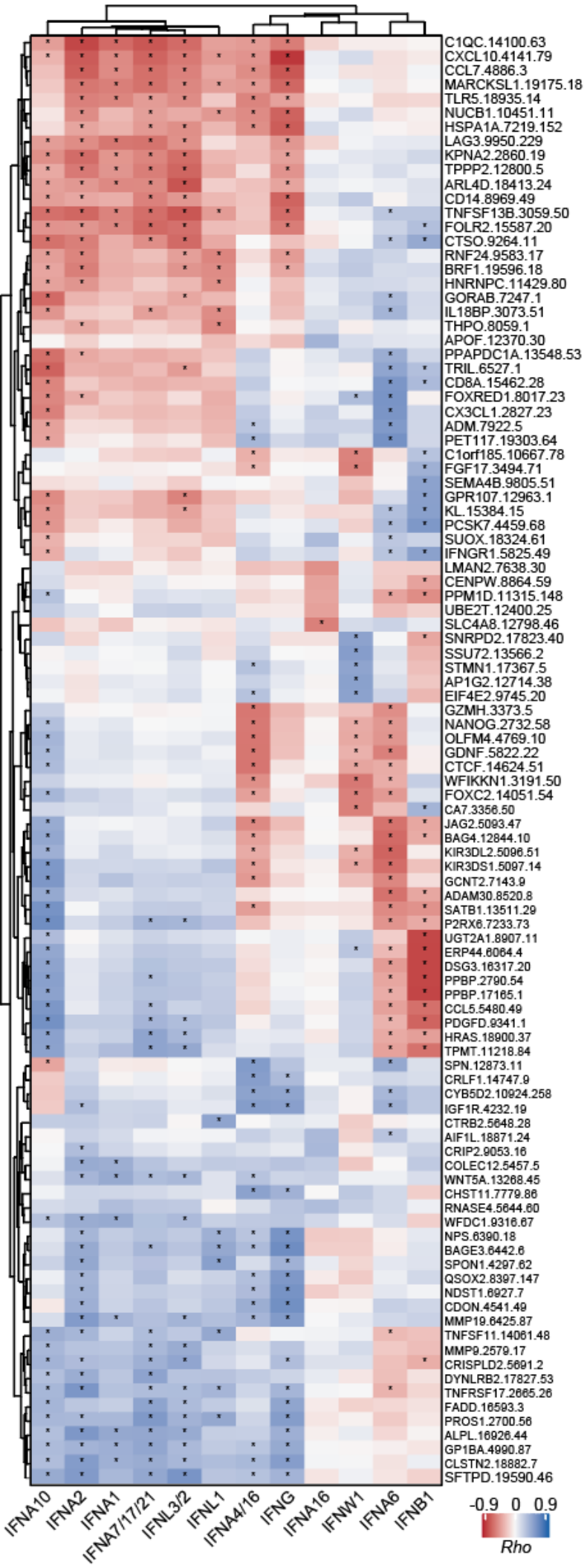

Figure 2 - supplement 2. Relationships between IFN ligands and SOMAscan ${ }^{\circledR}$ plasma proteomics. (A-B and D-H) Scatter plots comparing relationships between plasma proteins and the indicated IFNs in COVID19-positive patients. Points are colored by density; blue lines represent linear 
medRxiv preprint doi: https://doi.org/10.1101/2021.07.29.21261325; this version posted August 1, 2021. The copyright holder for this preprint (which was not certified by peer review) is the author/funder, who has granted medRxiv a license to display the preprint in perpetuity.

It is made available under a CC-BY 4.0 International license.

model fit with 95\% confidence intervals in grey. (C) Heatmap representing correlations between plasma levels of proteins measured by SOMAscan ${ }^{\circledR}$ and each IFN ligand. Values displayed are Spearman correlation scores (Rho) for proteins ranked in top 5 positive or top 5 negative correlations for at least one IFN; asterisks indicate significant correlations (10\% FDR); columns and rows are grouped by hierarchical clustering. 
medRxiv preprint doi: https://doi.org/10.1101/2021.07.29.21261325; this version posted August 1, 2021. The copyright holder for this preprint (which was not certified by peer review) is the author/funder, who has granted medRxiv a license to display the preprint in perpetuity.

It is made available under a CC-BY 4.0 International license .

\section{Differential relationship between IFN ligands and seroconversion status.}

Next, we analyzed correlations between the 12 IFN ligands and the MS plasma proteomics dataset.

The MS proteomics platform is highly complementary to the SOMAscan ${ }^{\circledR}$ dataset, as it detects many abundant proteins for which SOMAmer ${ }^{\circledR}$ reagents are not available, such as various immunoglobulins (Igs). Using a linear model adjusting for age and sex, we identified 70 proteins differentially abundant in the plasma of COVID19 patients (Figure 3 - supplement 1A, Supplementary file 10). Of the 28 significantly elevated proteins, 17 of them are Igs (labeled green in Figure 3 - supplement 1A), potentially indicative of production of anti-SARS-CoV-2 antibodies in COVID19 patients. We then defined Spearman correlations between IFN ligands and all proteins detected by MS (Figure 3 supplement 1B, Supplementary file 11) and visualized the top 5 positively and negatively correlated proteins for each ligand via unsupervised hierarchical clustering (Figure 3 - supplement 2A). This analysis confirmed some observations made with the SOMAscan ${ }^{\circledR}$ dataset, but also revealed several new associations. First, a subset of ligands associates strongly with recognizable IFN-inducible proteins such as B2M (beta-2-microglobulin, compare IFNA7/17/21 to IFNA6 in Figure 3A), and LGALS3BP (galectin 3 binding protein, compare IFNA4/16 to IFNA6 in Figure 3 - supplement 2B). Second, many of the same ligands associate with elevated levels of complement subunits such as C2 (compare IFNL1 to IFNA6 in Figure 3B) and C9 (compare IFNA2 to IFNA6 in Figure 3 - supplement 2C). Third, several key regulators of coagulation and fibrinolysis were significantly associated with specific ligands. Salient examples include HABP2 (Hyaluronan Binding Protein 2, compare IFNA2 to IFNB1 in Figure 3C), FGA (Fibrinogen Alpha Chain, compare IFNL1 to IFNA16 in Figure 3 - supplement 2D), F13B (Coagulation Factor XIII B Chain, compare IFNA10 to IFNA6 in Figure S6E), and PROZ (Protein Z, compare IFNW1 to IFNB1 in Figure 3 - supplement 2F). Fourth, very distinctly, IFNB1, and to a lesser degree IFNA6, associate positively with markers of platelet degranulation such as PF4, THBS1, PPBP, MMRN1, and SPARC (Figure 3 - supplement 2A, compare IFNB1 to IFNA10 in Figure 3D). Lastly, IFN ligands have clearly distinct relationships to a subset of immunoglobulin heavy and light chain variable domain peptides, that were either strongly positively or negatively regulated with the levels of 
medRxiv preprint doi: https://doi.org/10.1101/2021.07.29.21261325; this version posted August 1, 2021. The copyright holder for this preprint (which was not certified by peer review) is the author/funder, who has granted medRxiv a license to display the preprint in perpetuity.

It is made available under a CC-BY 4.0 International license .

specific ligands (compare IFNA2 to IFNA6 in Figure 3E and IFNA1 to IFNB1 in Figure 3F). This result could potentially be explained by varying levels of IFN ligands upon seroconversion (16).

In order to investigate in detail the interplay between specific IFN ligands, immunoglobulin expression, and seroconversion, we examined correlations between the ligands and all immunoglobulin variable domains detected by MS proteomics, as well as seroconversion assays used to detect lgGs against SARS-CoV-2 peptides (S1 full length, spike; S1 N-terminus; and S1 receptor binding domain, RBD; nucleocapsid) (Figure 3G). This analysis revealed that a subset of IFN ligands is strongly anticorrelated with seroconversion (e.g., compare IFNA2 to IFNB1 in Figure 3H) and specific Ig variable domains that have been previously found enriched in the bloodstream of COVID19 patients, such as IGHV1-24 and IGLV3-1 $(20,21)$. This could be interpreted as early production of some ligands which subsequently declines with seroconversion (e.g., IFNA2, IFNG), followed by later production of other ligands (e.g IFNA6, IFNB1), potentially from sites where SARS-CoV-2 evades humoral neutralization.

Overall, these results further support the notion of differential action of IFN ligands in COVID19 pathophysiology, suggesting a temporal sequence of IFN production prior and after seroconversion. 
medRxiv preprint doi: https://doi.org/10.1101/2021.07.29.21261325; this version posted August 1, 2021. The copyright holder for this preprint (which was not certified by peer review) is the author/funder, who has granted medRxiv a license to display the preprint in perpetuity.

It is made available under a CC-BY 4.0 International license.

A

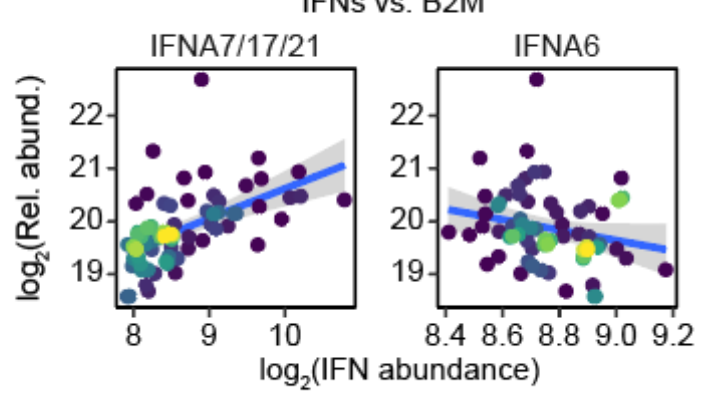

C

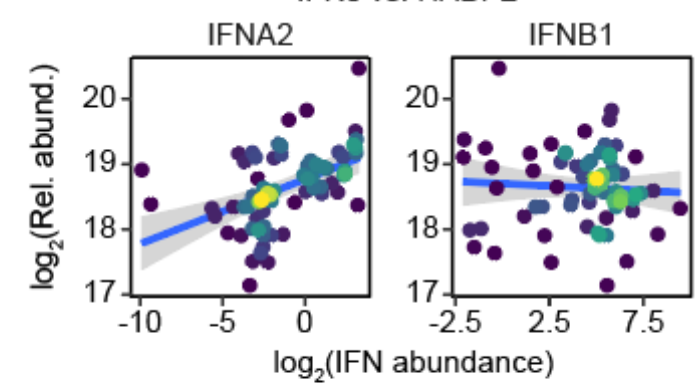

$\mathbf{E}$

IFNs vs. IGLV3-1

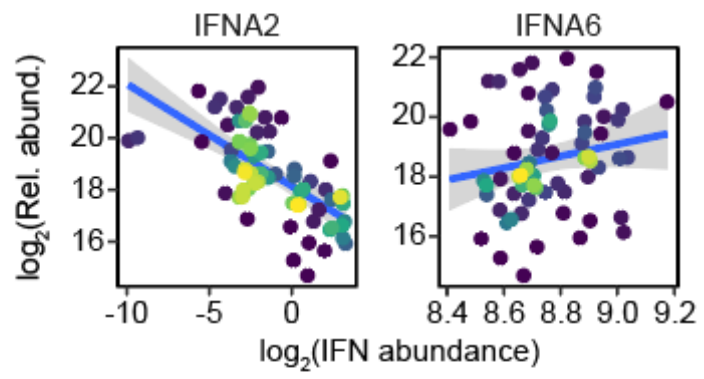

G

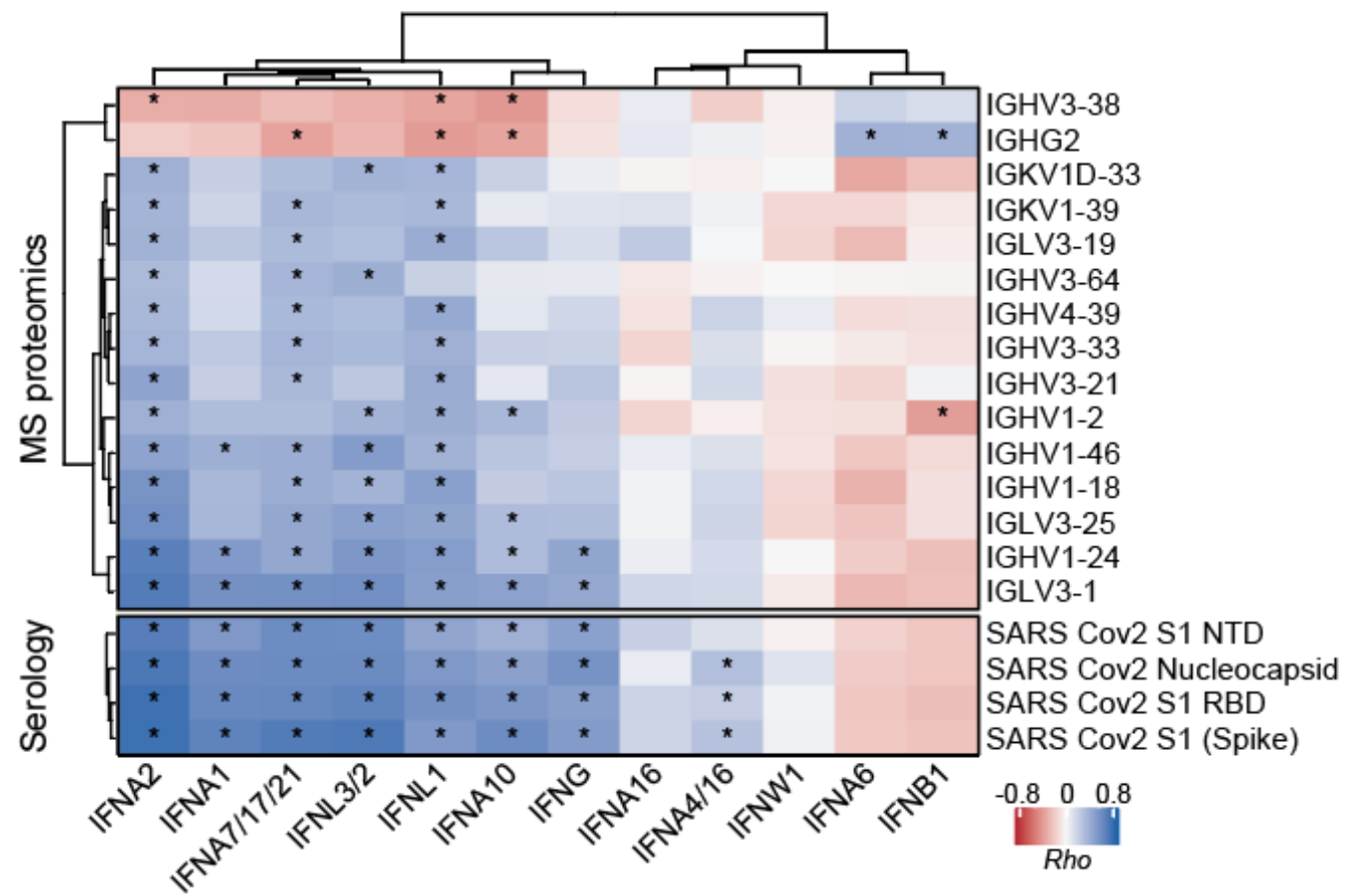

B

IFNs vs. C2

Figure 3

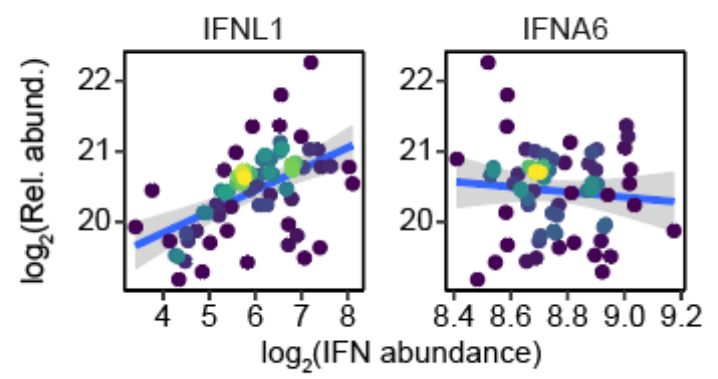

D

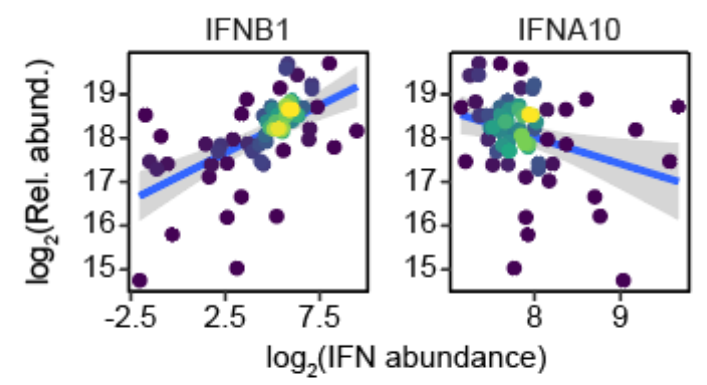

Density
50
150
250

F

IFNs vs. IGHV1-24

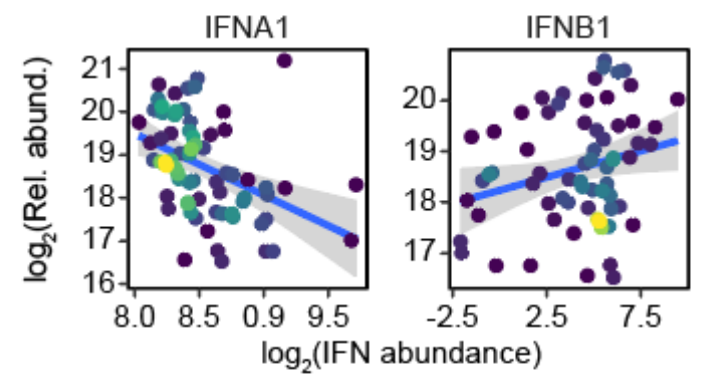

H IFNs vs. S1 RBD

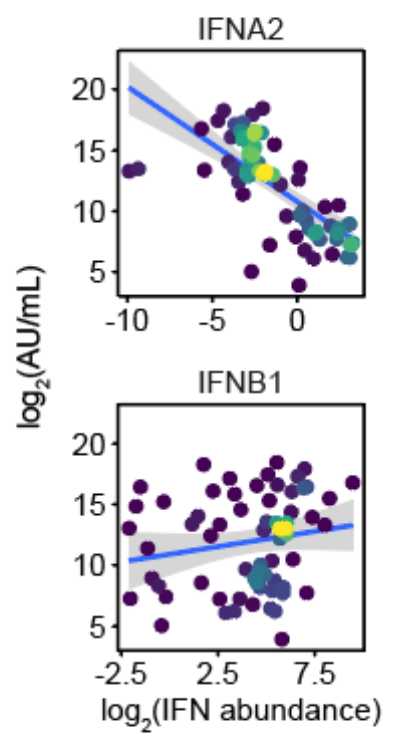

$50 \quad 150 \quad 250$
Density 
medRxiv preprint doi: https://doi.org/10.1101/2021.07.29.21261325; this version posted August 1, 2021. The copyright holder for this preprint (which was not certified by peer review) is the author/funder, who has granted medRxiv a license to display the preprint in perpetuity.

It is made available under a CC-BY 4.0 International license.

Figure 3. Differential association of IFN ligands with seroconversion. (A-F) Scatter plots comparing relationships between plasma proteins, as measured by MS proteomics, and the indicated IFNs in COVID19-positive patients. Points are colored by density; blue lines represent linear model fit with $95 \%$ confidence intervals in grey. (G) Heatmap representing correlations between IFN ligands and plasma levels of immunoglobulin subunits (top), as measured by MS proteomics, or antibody reactivity against SARS-CoV-2 (bottom), as measured by immunoassays. Only immunoglobulin subunits with at least two significant correlations are shown. Values displayed are Spearman correlation scores (Rho); asterisks indicate significant correlations (10\% FDR); columns and rows are grouped by hierarchical clustering. (H) Scatter plots comparing relationships between plasma antibody reactivity against SARSCoV-2 S1 RBD region and the indicated IFNs in COVID19-positive patients. Points are colored by density; blue lines represent linear model fit with 95\% confidence intervals in grey. See also Figure 3 supplement 1 and Figure 3 - supplement 2. 
medRxiv preprint doi: https://doi.org/10.1101/2021.07.29.21261325; this version posted August 1, 2021. The copyright holder for this preprint (which was not certified by peer review) is the author/funder, who has granted medRxiv a license to display the preprint in perpetuity.

It is made available under a CC-BY 4.0 International license .

A

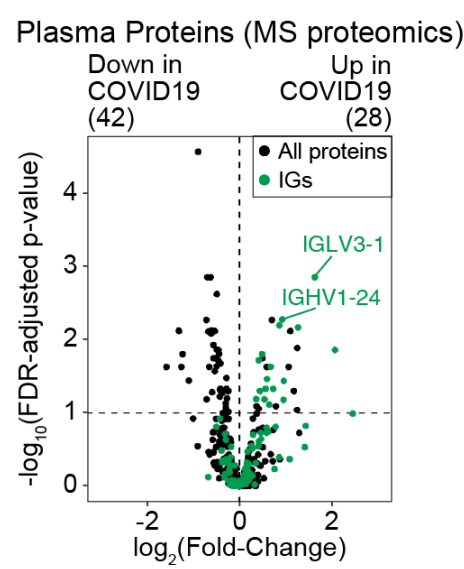

Figure 3 - supplement 1

B

Correlations: IFN ligands vs. MS Proteomics
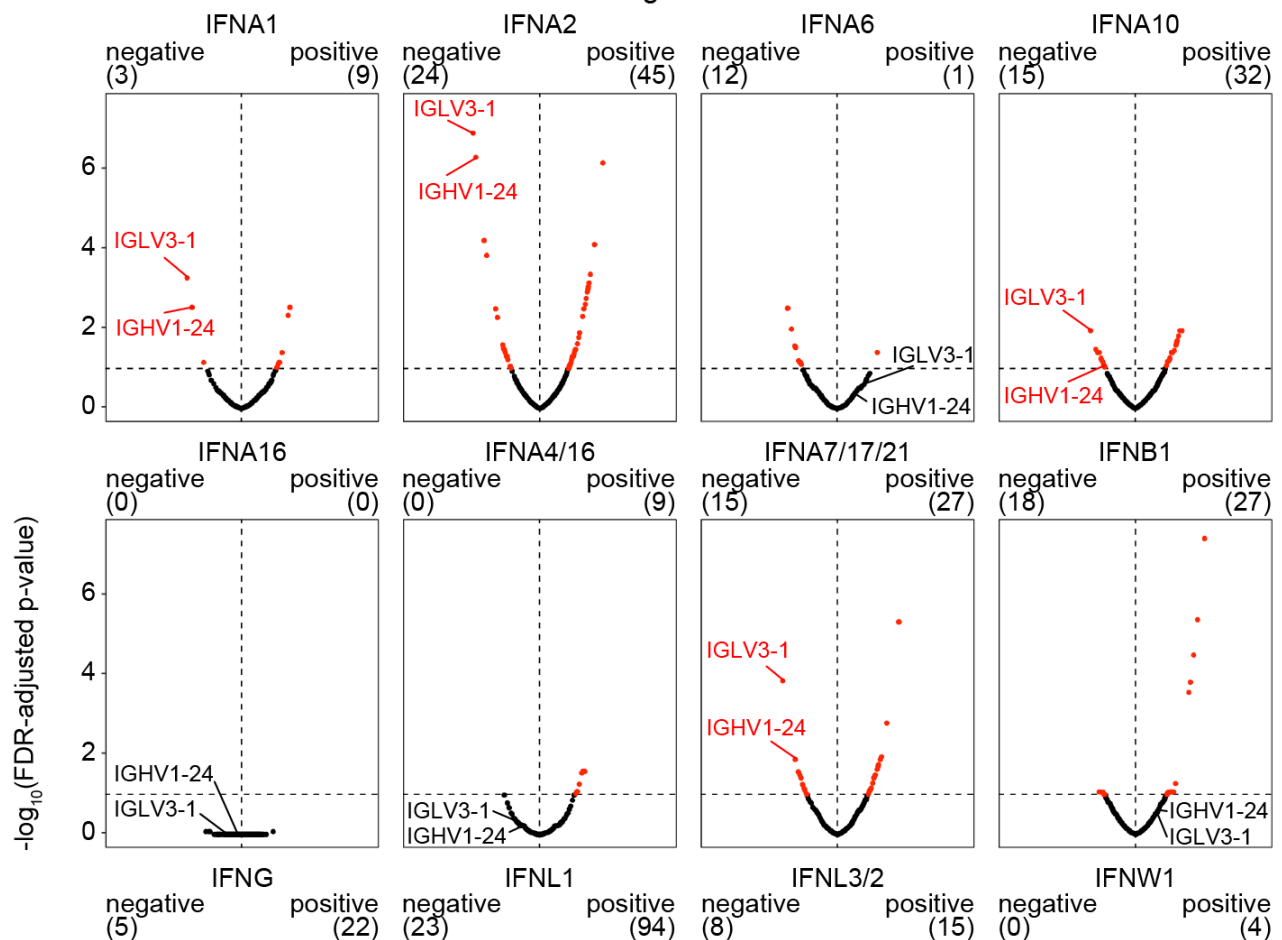

(9) (15)

IFNA7/17/21

IFNB1

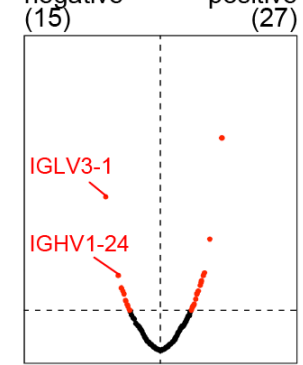

IFNL3/2
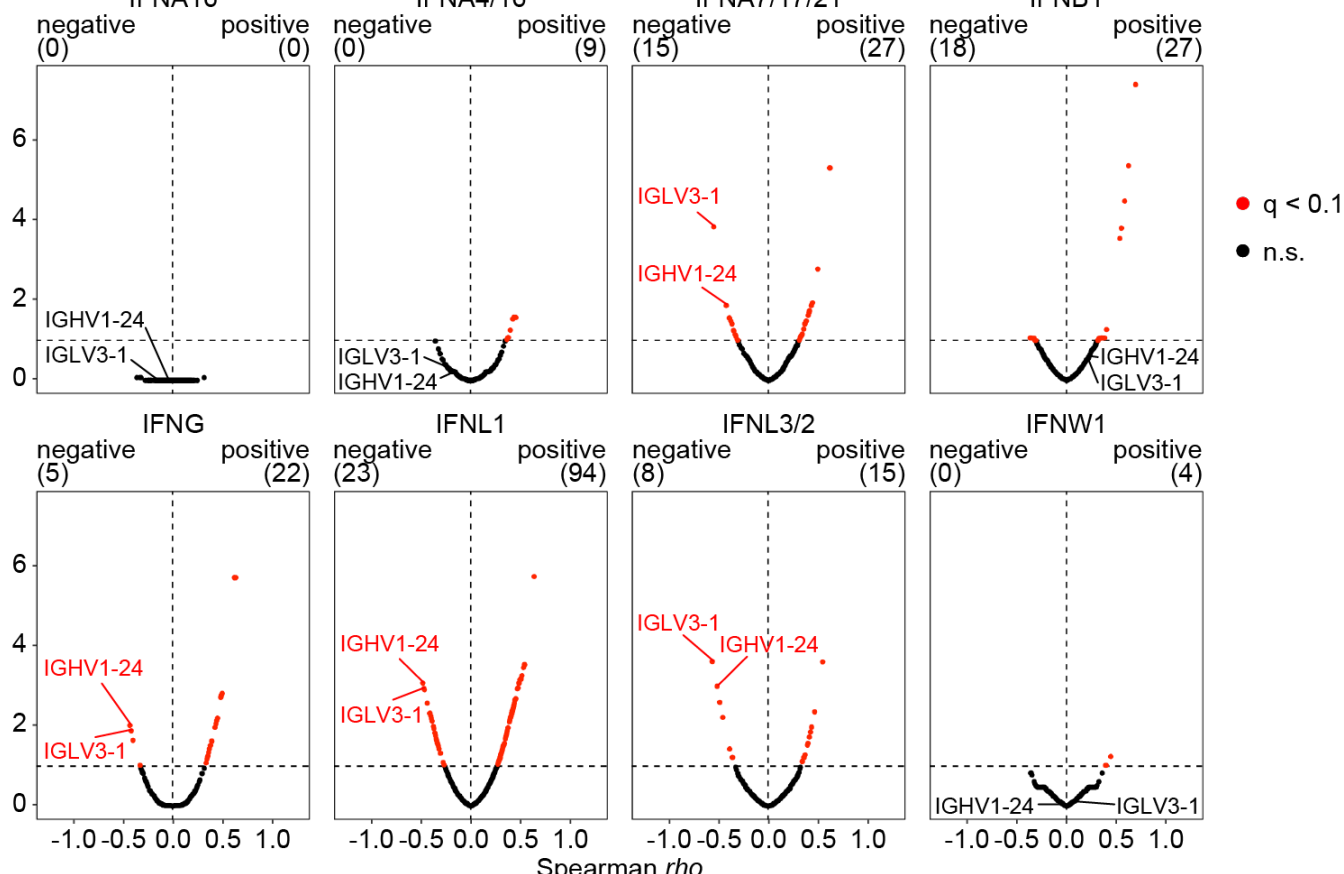

IFNW1

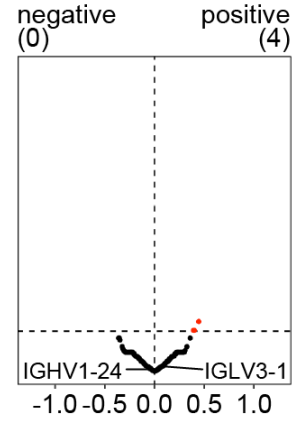

Figure 3 - supplement 1 . Differential abundance and correlation analysis for MS plasma proteomics. (A) Volcano plot for linear regression analysis of MS proteomics plasma protein abundance data for COVID19-positive vs. -negative samples, adjusted for age and sex. Horizontal dashed line indicates an FDR threshold of $10 \%(q<0.1)$; numbers above plot indicate significant genes at this threshold. Immunoglobulin subunits (IGs) are highlighted in green. (B) Volcano plots for Spearman correlation analysis of IFN ligands vs. MS proteomics protein relative abundance values. Horizontal dashed line indicates an FDR threshold of $10 \%(q<0.1)$; red points and numbers above plots indicate significant proteins at this threshold. 
medRxiv preprint doi: https://doi.org/10.1101/2021.07.29.21261325; this version posted August 1, 2021. The copyright holder for this preprint (which was not certified by peer review) is the author/funder, who has granted medRxiv a license to display the preprint in perpetuity.

It is made available under a CC-BY 4.0 International license.

A

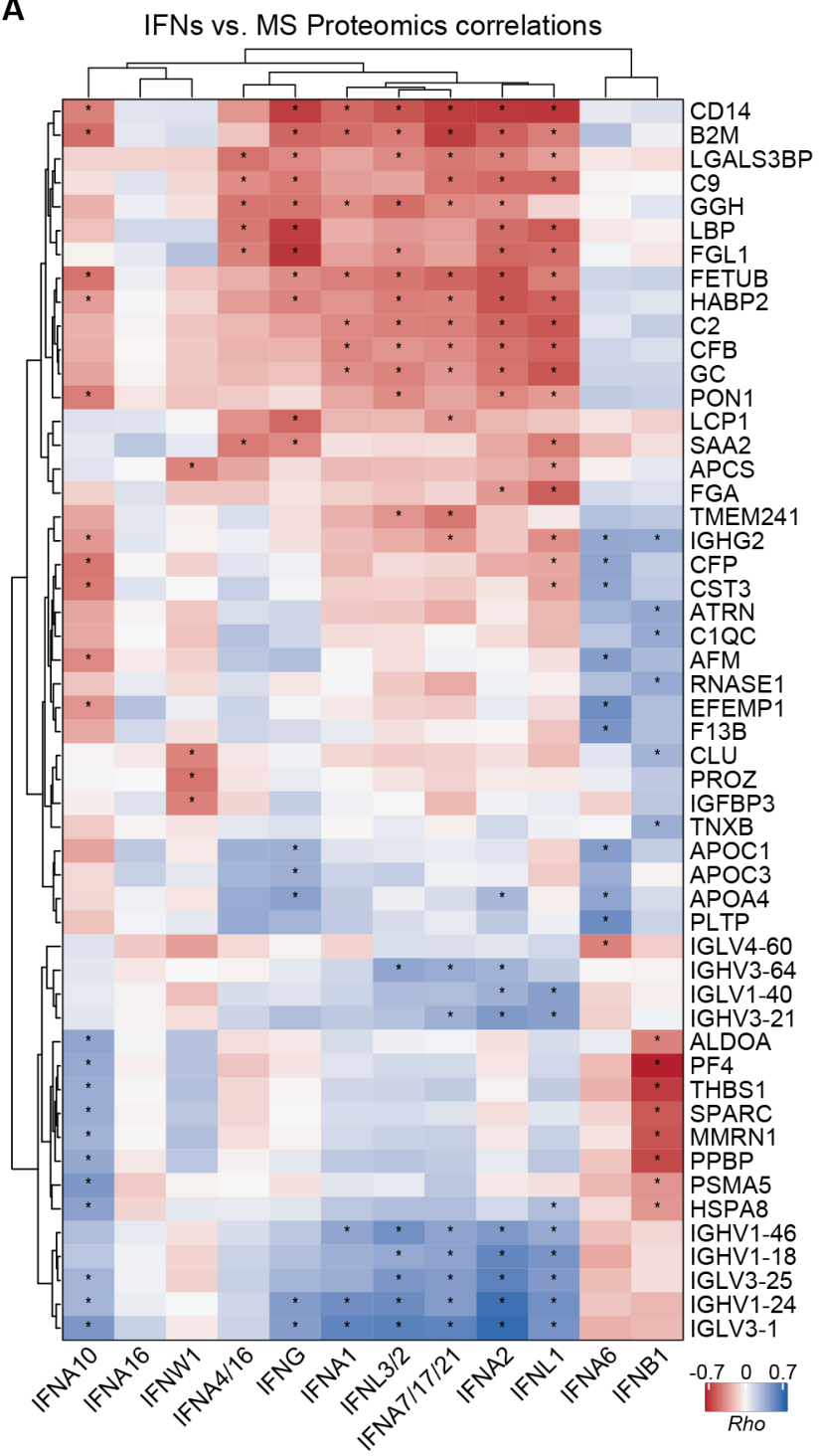

IFNs vs. MS Proteomics correlations

B

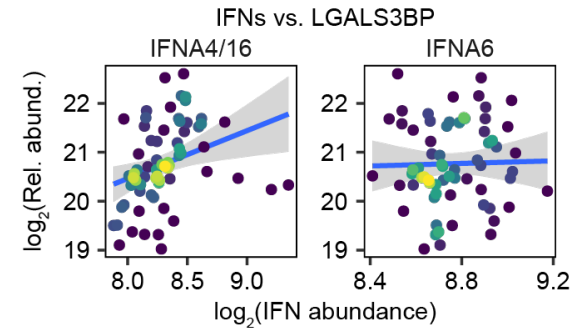

C

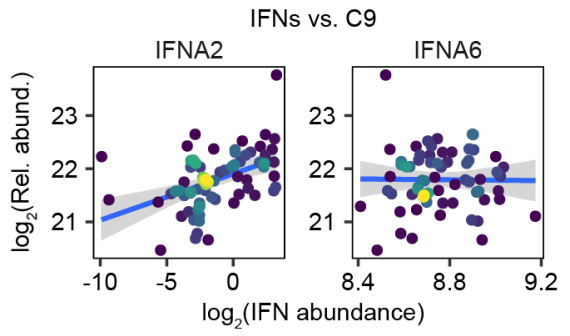

D

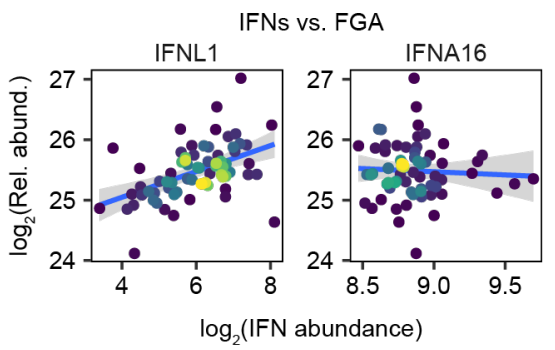

E

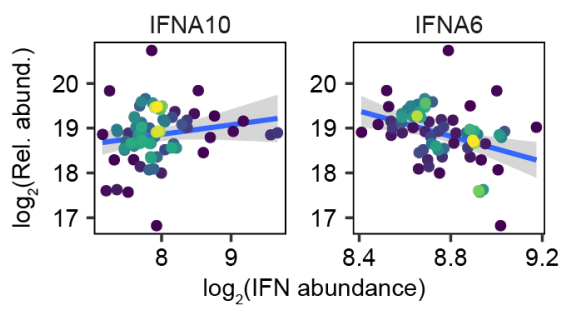

$\mathbf{F}$

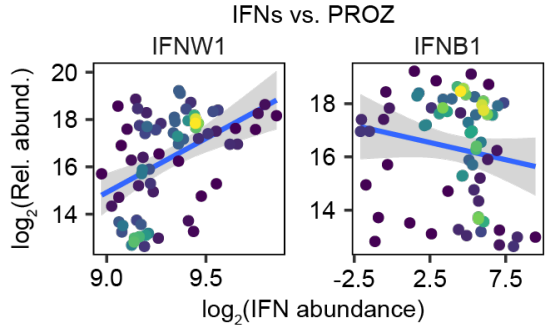

Figure 3 - supplement 2. Relationships between IFN ligands and MS plasma proteomics. (A) Heatmap representing correlations between IFN ligands and plasma protein levels, as measured by MS proteomics. Values displayed are Spearman correlation scores (Rho) for proteins ranked in top 5 positive or top 5 negative correlations for at least one IFN; asterisks indicate significant correlations (10\% FDR); columns and rows are grouped by hierarchical clustering. (B-F) Scatter plots comparing relationships between plasma proteins, as measured by MS proteomics, and the indicated IFNs in COVID19-positive patients. Points are colored by density; blue lines represent linear model fit with $95 \%$ confidence intervals in grey. 
medRxiv preprint doi: https://doi.org/10.1101/2021.07.29.21261325; this version posted August 1, 2021. The copyright holder for this preprint (which was not certified by peer review) is the author/funder, who has granted medRxiv a license to display the preprint in perpetuity.

It is made available under a CC-BY 4.0 International license.

\section{Differential immune cell signatures associated with fluctuations in IFN ligand levels.}

Next, we investigated the relationship between plasma levels of IFN ligands and circulating immune cells analyzed by mass cytometry which measured 38 features per cell event, including surface markers, activation molecules, and transcription factors. First, we employed the unsupervised clustering algorithm PhenoGraph (22) to identify distinct subpopulations of immune cells in the COVIDome mass cytometry dataset, combined with t-stochastic neighbor embedding (t-SNE) dimensionality reduction to aid in visualization $(23,24)$, resulting in identification of $\sim 30$ clusters, including subpopulations enriched for cell type-specific markers (see Methods, Figure 4 - supplement 1A-B). We then identified clusters whose relative frequency among all live cells was significantly associated with varying IFN ligand levels, using beta regression modelling with adjustment for age and sex (Figure 4A, Figure 4 - supplement 1C-D, Supplementary file 12). This analysis revealed that multiple IFN ligands are significantly associated with increased abundance of clusters enriched for T cells (Clusters 9, 13, 16, and 27, CD3+) and/or NK cells (Cluster 30, 16+ and/or 56+), while also displaying negative associations with clusters enriched for B cells (Clusters 7, 15, and 24, CD19+) (Figure 4A, Figure 4 - supplement 1C-D). For example, IFNA1 is positively associated with clusters 9 (CD8+ T cells) and 30 (CD56+ NK cells) and negatively associated with cluster 15 (Switched memory B cells) (Figure 4 - supplement 1E). In order to validate and investigate these observations more deeply in relationship to known immune cell sub-populations, we analyzed relations between the IFN ligands and 50+ immune cell types defined by traditional gating based on marker expression (Figure 4B, Figure 4 - supplement 2A, Supplementary file 13, see Methods). This exercise confirmed clear specialized relationships between IFN ligands and specific lymphoid cell subsets. For example, among CD4+ T cells, the Thelper 1 (Th1) subset displays significant positive associations only with IFNA1, IFNA2, IFNA7/17/21, IFNA10, IFNG, and IFNL3/2 (Figure 4B, compare IFNA10 to IFNA16 in Figure 4C). This pattern was also apparent for many, but certainly not all, T cell subsets (Figure 4B). Similarly, NK CD56 ${ }^{\text {bright }}$ cells also showed differential positive relationships with IFN ligands, with an overall pattern similar to that of key T cell subsets (compare IFNA2 to IFNA16 in Figure 4D). Notably, this analysis also revealed significant positive associations between specific ligands and plasmacytoid dendritic cells (pDCs), 
medRxiv preprint doi: https://doi.org/10.1101/2021.07.29.21261325; this version posted August 1, 2021. The copyright holder for this preprint (which was not certified by peer review) is the author/funder, who has granted medRxiv a license to display the preprint in perpetuity.

It is made available under a CC-BY 4.0 International license.

which are strong producers of IFNs during viral infections (compare IFNA10 to IFNA16 in Figure 4E).

Many of the IFN ligands positively associated with CD4+ T cell subsets were negatively associated with B cell subsets, while IFNA6 displays the opposite relationship (Figure 4B). This is clearly illustrated by plasmablasts (compare IFNA10 versus IFNA6 in Figure 4F). These differential associations could be interpreted as a transition from innate $\mathrm{T}$ cell-driven responses prior to seroconversion, followed by $\mathrm{B}$ cell activation and differentiation toward antibody-producing plasmablasts during seroconversion, along with decreased production of a specific subset of IFN ligands.

Altogether, these results suggest a temporal sequence of IFN ligand production in coordination with changes in the peripheral immune cell compartment, whereby a larger subset of ligands is produced early on during the innate immune response, whereas a few others are associated with development of the adaptive humoral response. An overview of salient IFN ligand associations along the paths of $\mathrm{T}$ cell and B cell activation and differentiation is shown in Figure 4 - supplement 2B. 
medRxiv preprint doi: https://doi.org/10.1101/2021.07.29.21261325; this version posted August 1, 2021. The copyright holder for this preprint (which was not certified by peer review) is the author/funder, who has granted medRxiv a license to display the preprint in perpetuity.

It is made available under a CC-BY 4.0 International license.

A

IFN ligands vs. Phenograph Clusters

Figure 4

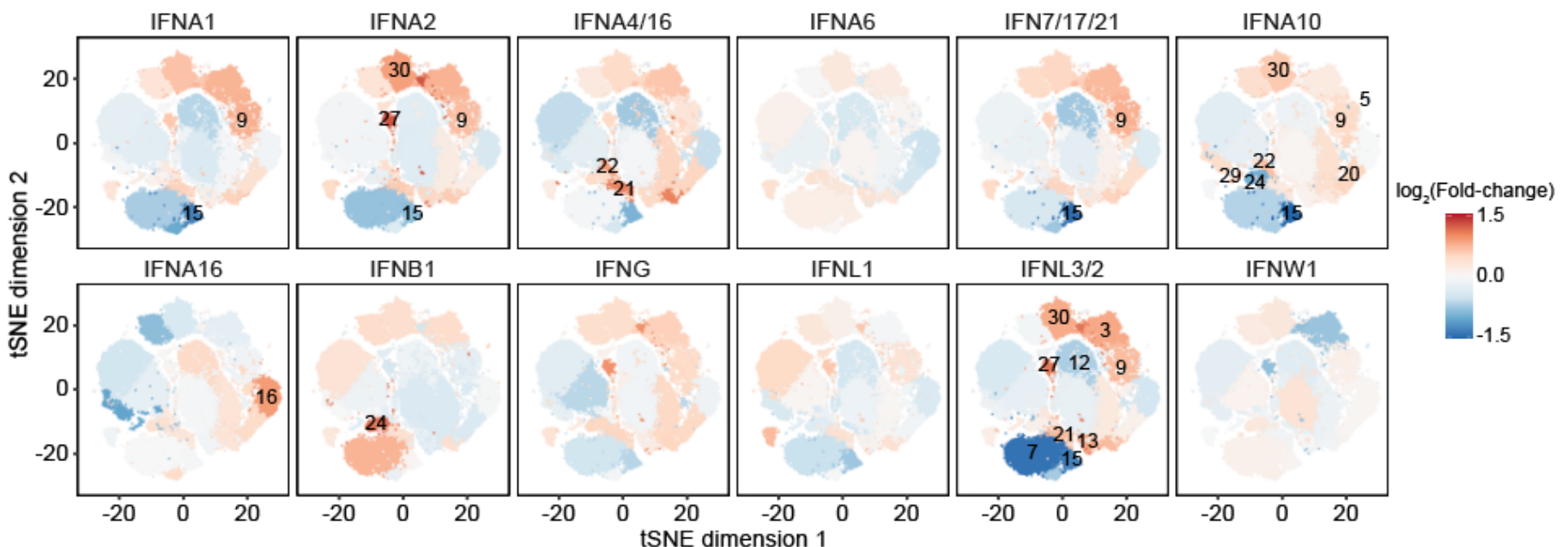

B

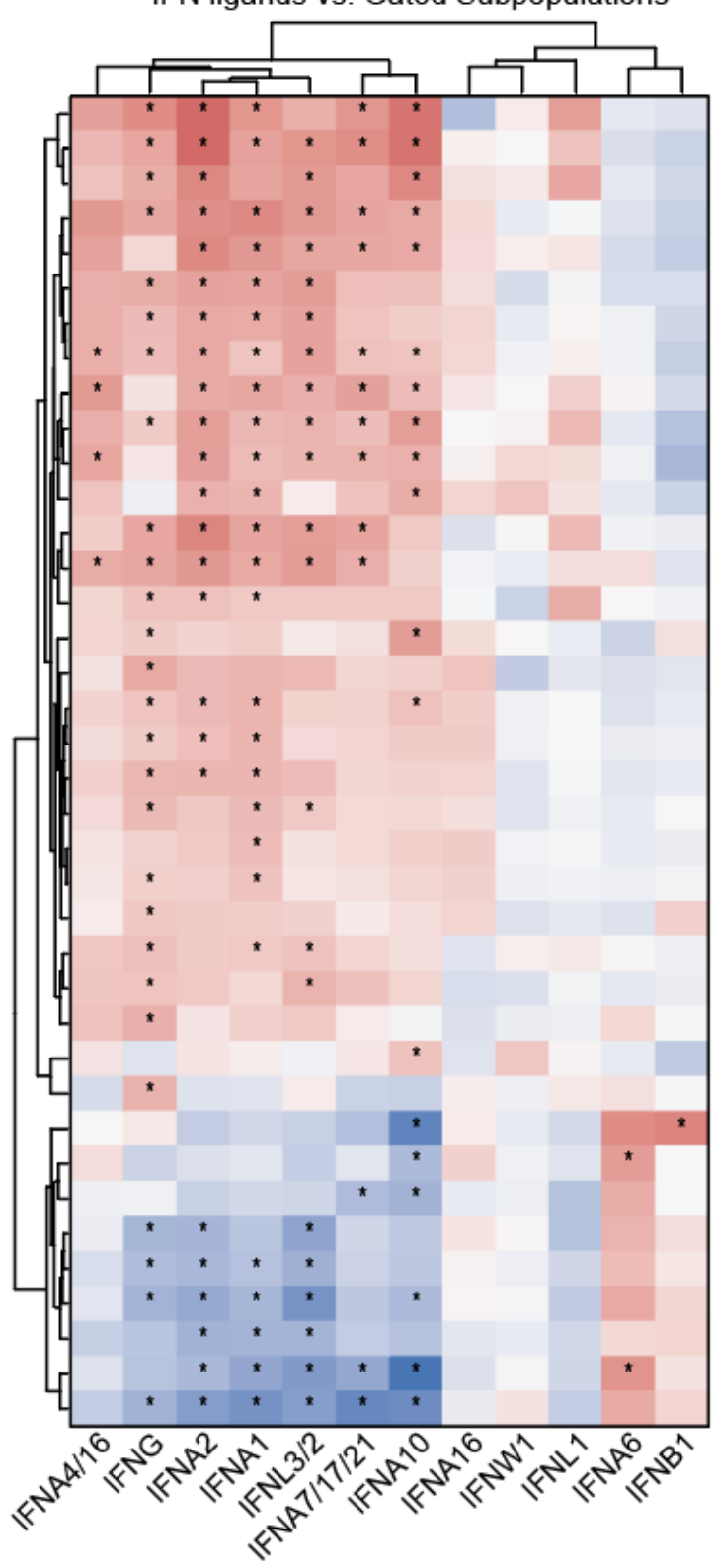

Plasmacytoid DCs

Th1

Th1/17

T-bet+ Eomes- CD8 T

Effector Memory CD8 T

Effector Memory CD45RA+ CD8 T CD27- CD57- CD8 T

Effector Memory CD45RA+ CD4 T

CD4-CD8- T

Th17

Effector Memory CD4 T

Central Memory CD8 T

CD56bright NK

Follicular helper CD4 T

Intermediate Monocytes

Memory Stem CD8 T

CD27- CD57+ CD8 T

CD95+ CD8 T

$\mathrm{CD} 38+\mathrm{CD} 8 \mathrm{~T}$

T-bet+ Eomes+ CD8 T

HLA-DR+ CD8 T

$\mathrm{CD} 8+\mathrm{T}$

$\mathrm{PD}-1+\mathrm{CD} 8 \mathrm{~T}$

CD27+ CD57+ CD8 T

CD56midCD16hi NK

Regulatory $T$

Non-Classical Monocytes

Central memory CD4 T

Myeloid Dendritic Supressor Cells

Plasmablasts

Immature Naive B

Age-Dependent $B(A B C)$

Mature Naive $B$

Pre-switched Activated Memory B CD19+ B cells

c-delta Switched Memory B

$\lg \mathrm{M}+$ Memory $\mathrm{B}$

Switched Memory B

$-0.8-0 \quad 0.8$

$\log _{2}($ Fold-change $)$
C
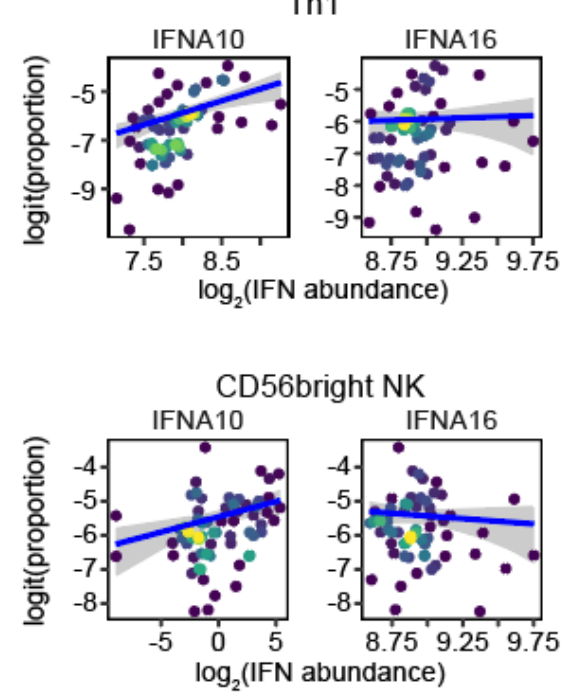

E

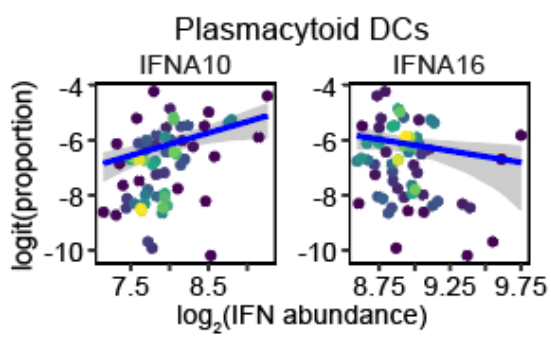

F
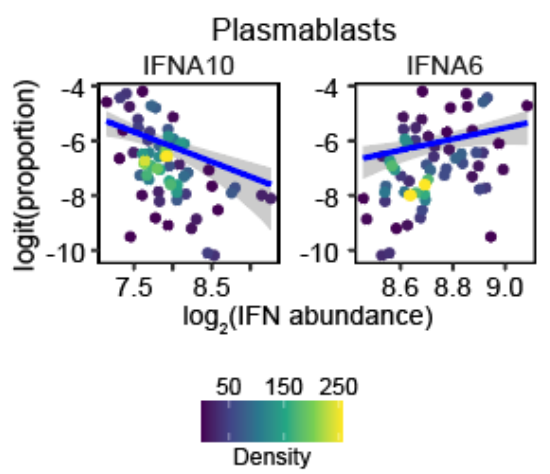
medRxiv preprint doi: https://doi.org/10.1101/2021.07.29.21261325; this version posted August 1, 2021. The copyright holder for this preprint (which was not certified by peer review) is the author/funder, who has granted medRxiv a license to display the preprint in perpetuity.

It is made available under a CC-BY 4.0 International license.

Figure 4. Differential association of IFN ligands with immune cell signatures. (A) t-SNE plots of 69,000 cells analyzed by mass cytometry from 69 COVID19-positive patients (1,000 cells each). All cells within each PhenoGraph cluster (as in Figure 4 - supplement $1 \mathrm{~A}$ ) are colored by the fold-change in cluster proportion among live cells per standard deviation of abundance for the indicated IFN, as determined by beta regression analysis, adjusting for Age and Sex; numbers indicate clusters with significant associations with IFN abundance (10\% FDR). (B) Heatmap representing relationships between IFN ligands and gated subpopulation proportions among live cells, as determined by beta regression analysis. Only subpopulations with at least one significant association are shown. Values displayed are fold-change in cluster proportion among live cells per standard deviation of IFN abundance; asterisks indicate significant associations (10\% FDR); columns and rows are grouped by hierarchical clustering. (C-F) Scatter plots comparing relationships between gated subpopulation proportions among live cells, and the indicated IFNs in COVID19-positive patients. Points are colored by density; blue lines represent beta regression model fit with $95 \%$ confidence intervals in grey. See also Figure 4 - supplement 1 and Figure 4 - supplement 2. 
medRxiv preprint doi: https://doi.org/10.1101/2021.07.29.21261325; this version posted August 1, 2021. The copyright holder for this preprint (which was not certified by peer review) is the author/funder, who has granted medRxiv a license to display the preprint in perpetuity.

It is made available under a CC-BY 4.0 International license .

A

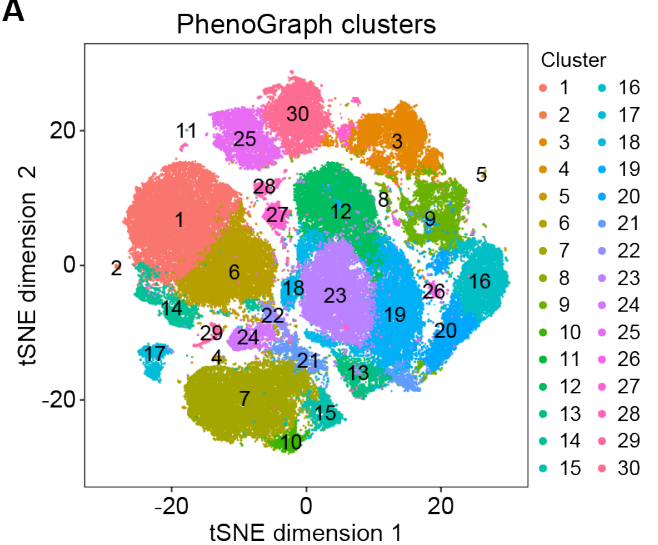

B

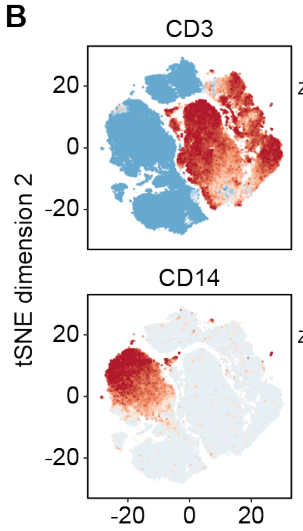

Figure 4 - supplement 1

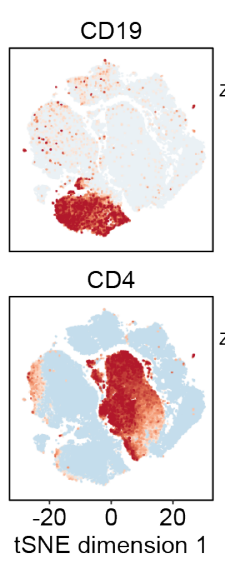

CD16

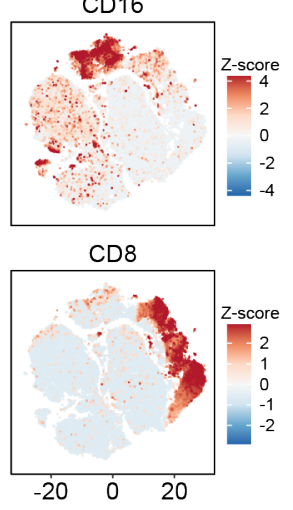

C

IFN ligands vs. Live Cell Phenograph Clusters

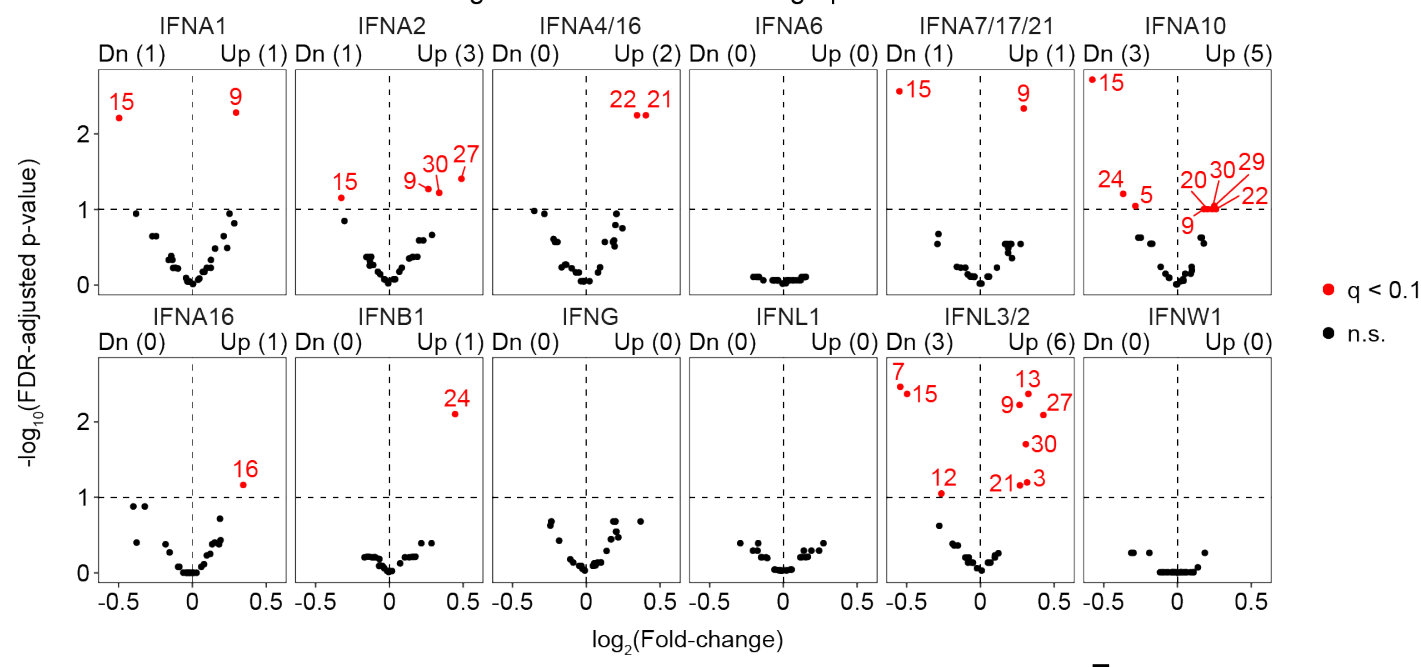

D

IFN z-scores vs. PhenoGraph Cluster Proportions

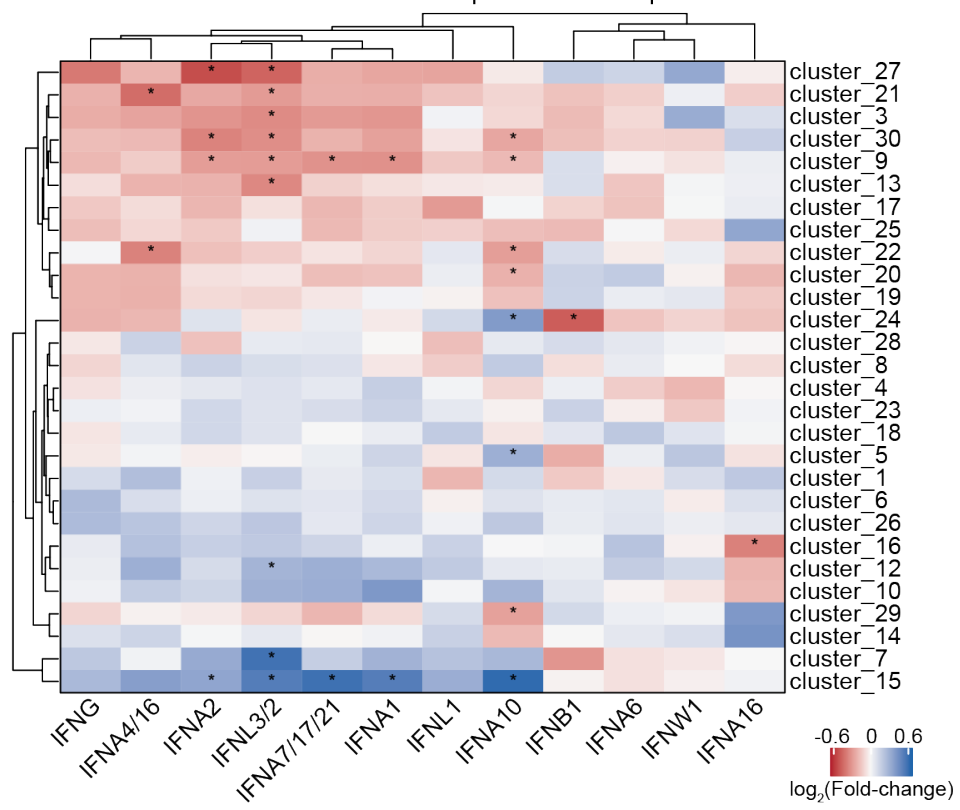

$E$
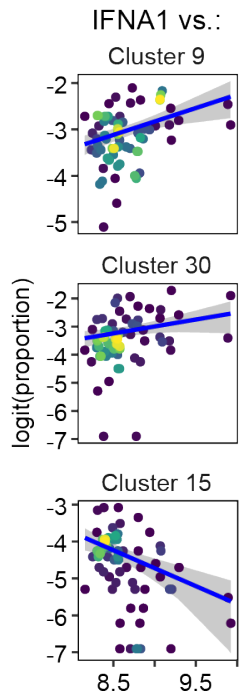

$\log _{2}$ (IFN abundance)

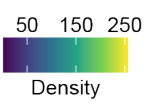

Figure 4 - supplement 1 . PhenoGraph clustering and beta regression analysis of clustered mass cytometry data against IFN ligands. (A) t-SNE plots of 69,000 cells analyzed by mass cytometry from 69 COVID19-positive patients (1,000 cells each). Numbers and coloring of cells indicate PhenoGraph cluster assignments. (B) t-SNE plots with cells colored by Z-scores for markers of T cells 
medRxiv preprint doi: https://doi.org/10.1101/2021.07.29.21261325; this version posted August 1, 2021. The copyright holder for this preprint (which was not certified by peer review) is the author/funder, who has granted medRxiv a license to display the preprint in perpetuity.

It is made available under a CC-BY 4.0 International license.

(CD3, CD4, CD8), B cells (CD19), NK cells (CD16), and Monocytes (CD14). (C) Volcano plots for Beta regression analysis of IFN ligands vs. cluster proportions among live cells, adjusted for age and sex. Xaxes display log2-transformed fold-change in cluster proportion among live cells per standard deviation of IFN abundance; horizontal dashed line indicates an FDR threshold of $10 \%(q<0.1)$; red points and numbers above plots indicate significant clusters at this threshold. (D) Heatmap representing relationships between IFN ligands and cluster proportions among live cells, as determined by beta regression analysis. Values displayed are fold-change in cluster proportion among live cells per standard deviation of IFN abundance; asterisks indicate significant associations (10\% FDR); columns and rows are grouped by hierarchical clustering. (E) Scatter plots comparing relationships between cluster proportions among live cells, and the indicated IFNs in COVID19-positive patients. Points are colored by density; blue lines represent beta regression model fit with $95 \%$ confidence intervals in grey. 
medRxiv preprint doi: https://doi.org/10.1101/2021.07.29.21261325; this version posted August 1, 2021. The copyright holder for this preprint (which was not certified by peer review) is the author/funder, who has granted medRxiv a license to display the preprint in perpetuity.

It is made available under a CC-BY 4.0 International license .

A

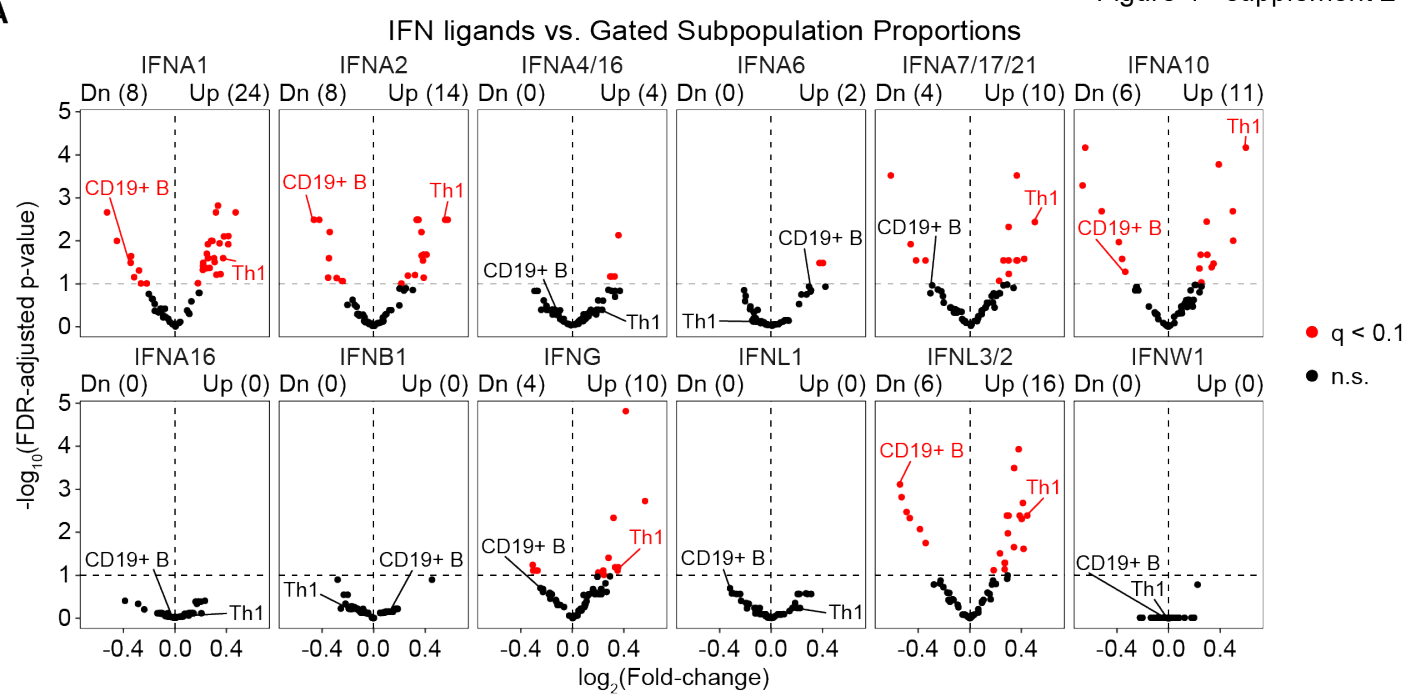

B

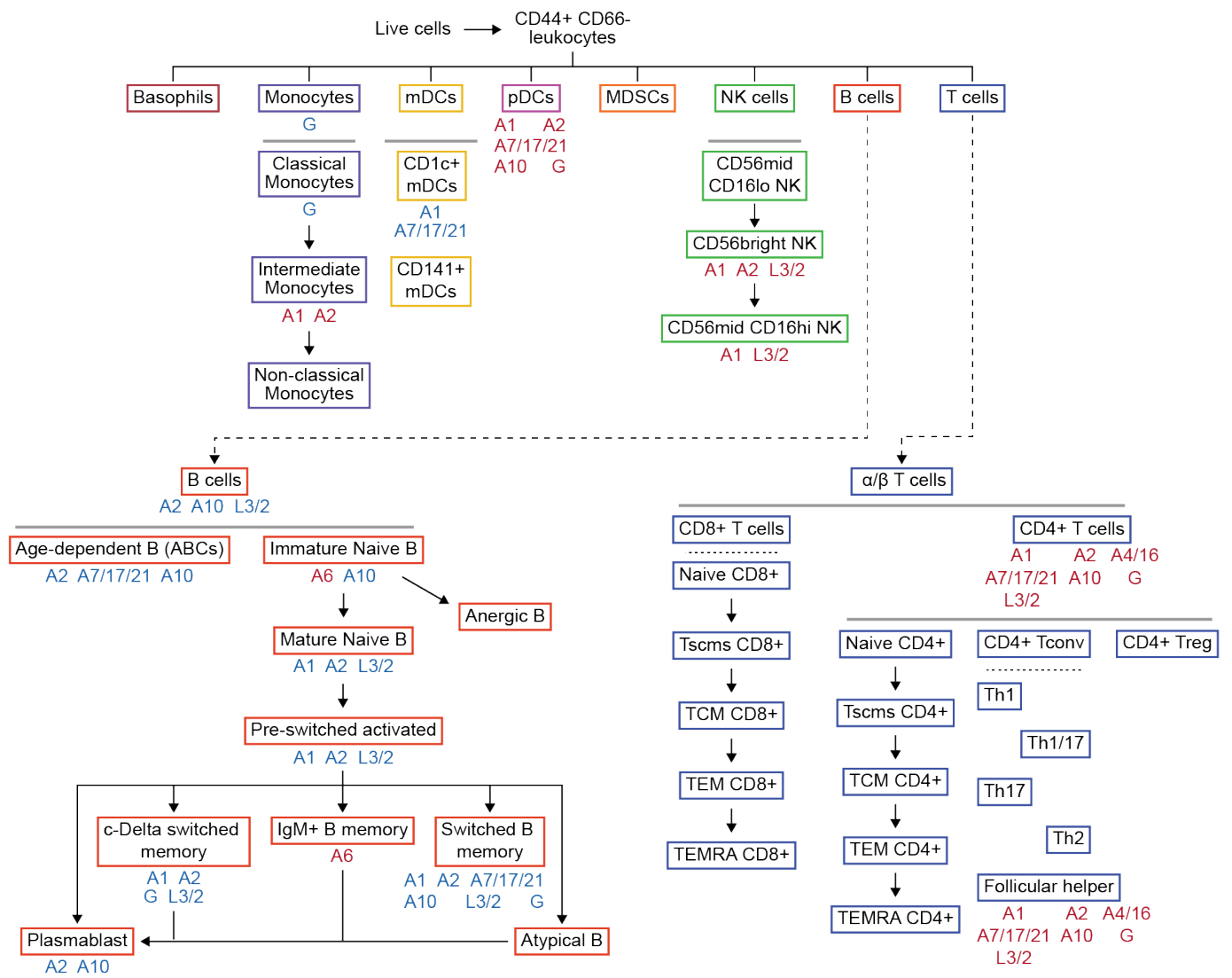

Figure 4 - supplement 2. Beta regression analysis of gated mass cytometry data against IFN ligands. (A) Volcano plots for Beta regression analysis of IFN ligands vs. gated subpopulation proportions among live cells, adjusted for age and sex. X-axes display log2-transformed fold-change in cluster proportion among live cells per standard deviation of IFN abundance; horizontal dashed line indicates an FDR threshold of $10 \%(q<0.1)$; red points and numbers above plots indicate significant subpopulations at this threshold. (B) Cell lineage map indicating the relationships between gated cell subpopulations included in beta regression analysis. Boxed labels represent subpopulations for which relative cell frequencies were obtained. Grey horizontal lines denote subpopulations of cells derived by gating; black lines and arrows indicate subpopulations that are also related by cell differentiation; labels outside boxes indicate significant positive (red) and negative (blue) relationships with IFN ligands. 
medRxiv preprint doi: https://doi.org/10.1101/2021.07.29.21261325; this version posted August 1, 2021. The copyright holder for this preprint (which was not certified by peer review) is the author/funder, who has granted medRxiv a license to display the preprint in perpetuity.

It is made available under a CC-BY 4.0 International license.

\section{Metabolic signatures of IFN ligand action.}

Next, we investigated metabolic signatures associated with varying levels of IFN ligands, calculating Spearman correlations for detected metabolites in plasma and red blood cell (RBC) samples against each of the IFN ligands (Figure 5A-B, Figure 5 - supplement $1 A-B$, Supplementary files $14-15$, see Methods). In plasma, significant positive correlations were observed between the tryptophan/indole pathway metabolites kynurenine and 5-hydroxyindoleacetate and IFNG, but not other IFNs (compare IFNG to IFNA16 in Figure 5C). In RBCs, kynurenine levels (as well as those of indoxyl, another tryptophan/indole metabolite) showed a strong positive association with IFNG, as well as IFNA7/17/21 (compare IFNG to IFNA7/17/21 in Figure 5D). Activation of the kynurenine pathway has been well documented in COVID19 (25-29). Kynurenine production can be stimulated by induction of IDO1 (indoleamine-2,3-dioxygenase 1), an ISG downstream of all three major types of IFN signaling (30). Therefore, it is interesting that this pathway is preferentially associated with IFNG in COVID19. Plasma levels of IFNA2 showed significant positive correlations with the markers of oxidative stress glutathione disulfide and 5-oxoproline, a byproduct of the gamma-glutamyl cycle (Figure 5A, compare IFNA2 to IFNW1 in Figure 5 - supplement 1 C), and negatively associated with markers of endothelial dysfunction and nitric oxide signaling (arginine, citrulline) (Figure 5A, compare IFNA2 to IFNW1 in Figure 5 - supplement 1D), as well as metabolites of potential bacterial or iatrogenic origin (mannitol) and derived from purine oxidation (hypoxanthine) (Figure 5A). In RBCs, IFNA2 had once again strong positive correlations with several markers of oxidative stress (5-oxoproline) or pentose phosphate pathway activation (sedoheptulose phosphate) (Figure 5B, compare IFNA2 to IFNB1 in Figure 5E), which is required in $\mathrm{RBCs}$ to generate reducing equivalent (NADPH) for recycling oxidized glutathione and other NADPH-dependent antioxidant enzymes. IFNA2 levels also positively correlated with fatty acid mobilization in RBCs- perhaps as a result of the activity of peroxiredoxin 6 (31) or phospholipase A2 activity $(32,33)$ on complex lipids to fuel fatty acid release in the bloodstream to sustain viral capsid formation (34). Of note, among the positive correlates to IFNA2 levels in the fatty acid compartment, we observed only saturated (octanoic, dodecanoic, hexadecenoic, octadecanoic) or monounsaturated fatty acids (tetradecenoic, hexadecenoic, octadecenoic) (compare IFNA2 to IFNB1 in Figure 5F), suggestive 
medRxiv preprint doi: https://doi.org/10.1101/2021.07.29.21261325; this version posted August 1, 2021. The copyright holder for this preprint (which was not certified by peer review) is the author/funder, who has granted medRxiv a license to display the preprint in perpetuity.

It is made available under a CC-BY 4.0 International license .

of limited fatty acid desaturase activation despite the stress induced by the viral infection (35). Several ATP precursors/breakdown products (AMP and adenine) positively correlated with IFNA2 in RBCs, as did pyruvate, phosphate and diphosphate - suggestive of altered glycolysis and overall energetics as a function of IFNA2 signaling. IFNA2 also negatively correlated with several amino acids in RBCs, including the antioxidants taurine, arginine, threonine and methionine - critical for RBC redox damage repair in the face of the incapacity to synthesize new proteins (36).

Plasma IFNL1 significantly correlated with several glycolytic metabolites (e.g. pyruvate, compare IFNL1 to IFNA1 in Figure 5G), as well as short chain fatty acids hexanoate and heptanoate, potentially indicative of dysregulation of mitochondrial metabolism in patients with high IFNL1. In RBCs, IFNL1 levels showed positive correlations with the levels of IDP (compare IFNL1 to IFNA6 in Figure 5 supplement 1E) and negative correlations with carnitine and acetyl-carnitine, potentially suggestive of RBC deformability issues $(37,38)$ as a function of IFNL1 signaling.

Plasma IFNA7 and IFNA10 (and to a lesser extent - IFNA1 and IFNA2) were positively associated with a cluster of acyl-carnitines (including octenoyl, dodecanoyl, dodecenoyl, hexadecenoyl-carnitine, compare IFNA10 to IFNA6 in Figure 5H), suggesting an association between these IFN ligands and altered fatty acid oxidation. These data are relevant in light of the role of acyl-carnitines in coagulation (39) and the common thromboembolic complications and dysregulation of coagulation cascades in COVID19 patients associated with inflammatory markers such as IL-6 (40).

Plasma levels of IFNB1 showed strong negative correlation with metabolites tied to the nitric oxide pathway (citrulline), as well as other amine group donors (glutamine, serine) or oxidant stress-related metabolites (carnosine, cystine). On the other hand, IFNB1 positively correlated with the plasma levels of glutathione and spermidine (antioxidant metabolites), succinate (marker of mitochondrial dysfunction), and purinergic agonists involved in vasodilatory/hypoxic responses (ADP and AMP), perhaps produced by hemolytic events (compare IFNB1 to IFNA10 in Figure 5I and Figure 5 -

\section{supplement 1F-G).}


medRxiv preprint doi: https://doi.org/10.1101/2021.07.29.21261325; this version posted August 1, 2021. The copyright holder for this preprint (which was not certified by peer review) is the author/funder, who has granted medRxiv a license to display the preprint in perpetuity.

It is made available under a CC-BY 4.0 International license .

Altogether, these results not only confirm metabolic signatures previously associated with IFN signaling (e.g. activation of the kynurenine pathway), but also reveal unexpected associations between specific

IFN ligands and diverse metabolic processes with ties to COVID19 pathophysiology. 
medRxiv preprint doi: https://doi.org/10.1101/2021.07.29.21261325; this version posted August 1, 2021. The copyright holder for this preprint (which was not certified by peer review) is the author/funder, who has granted medRxiv a license to display the preprint in perpetuity.

A IFN ligands vs. Plasma Metabolites

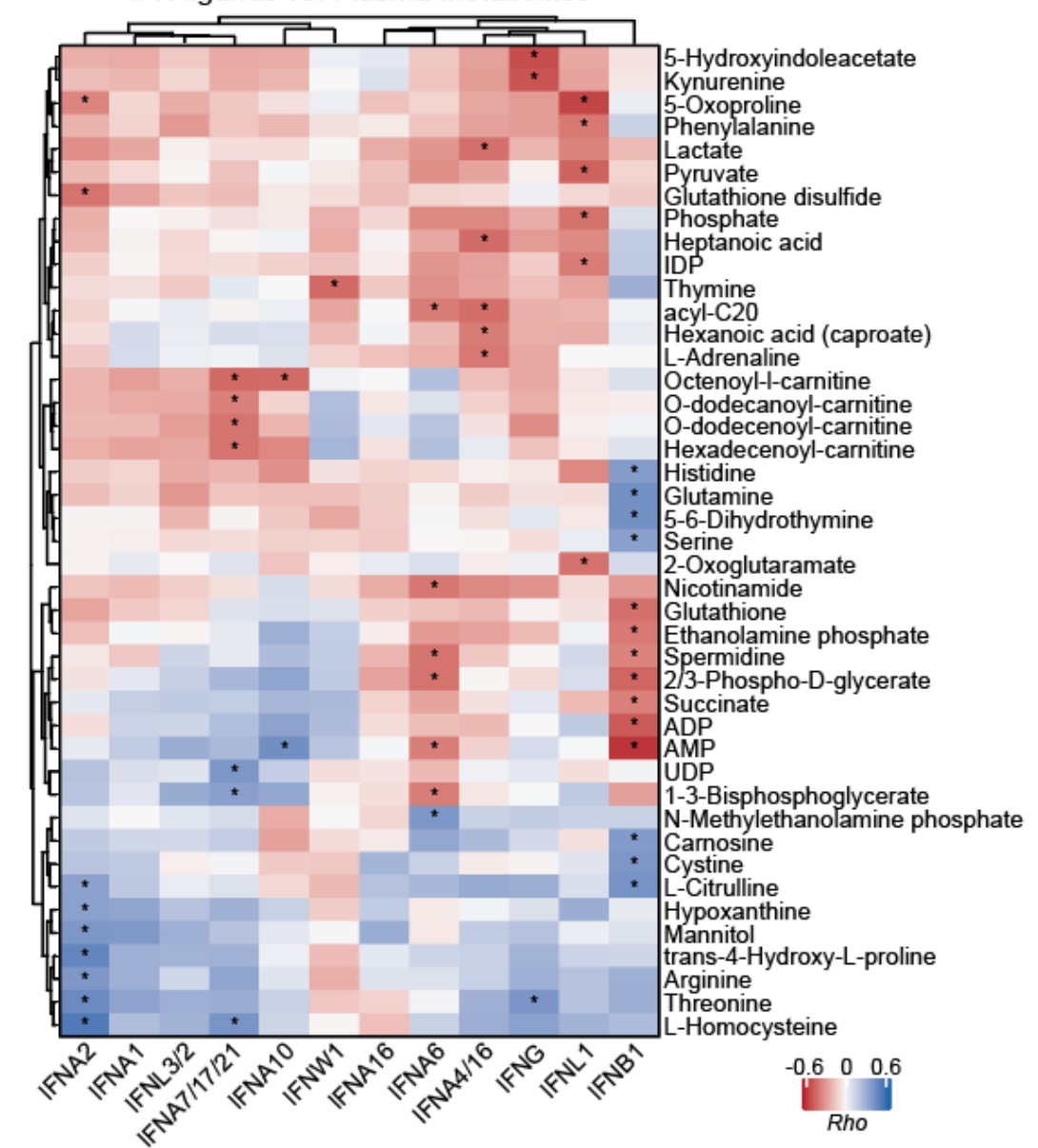

B IFN ligands vs. Red Blood Cell Metabolites

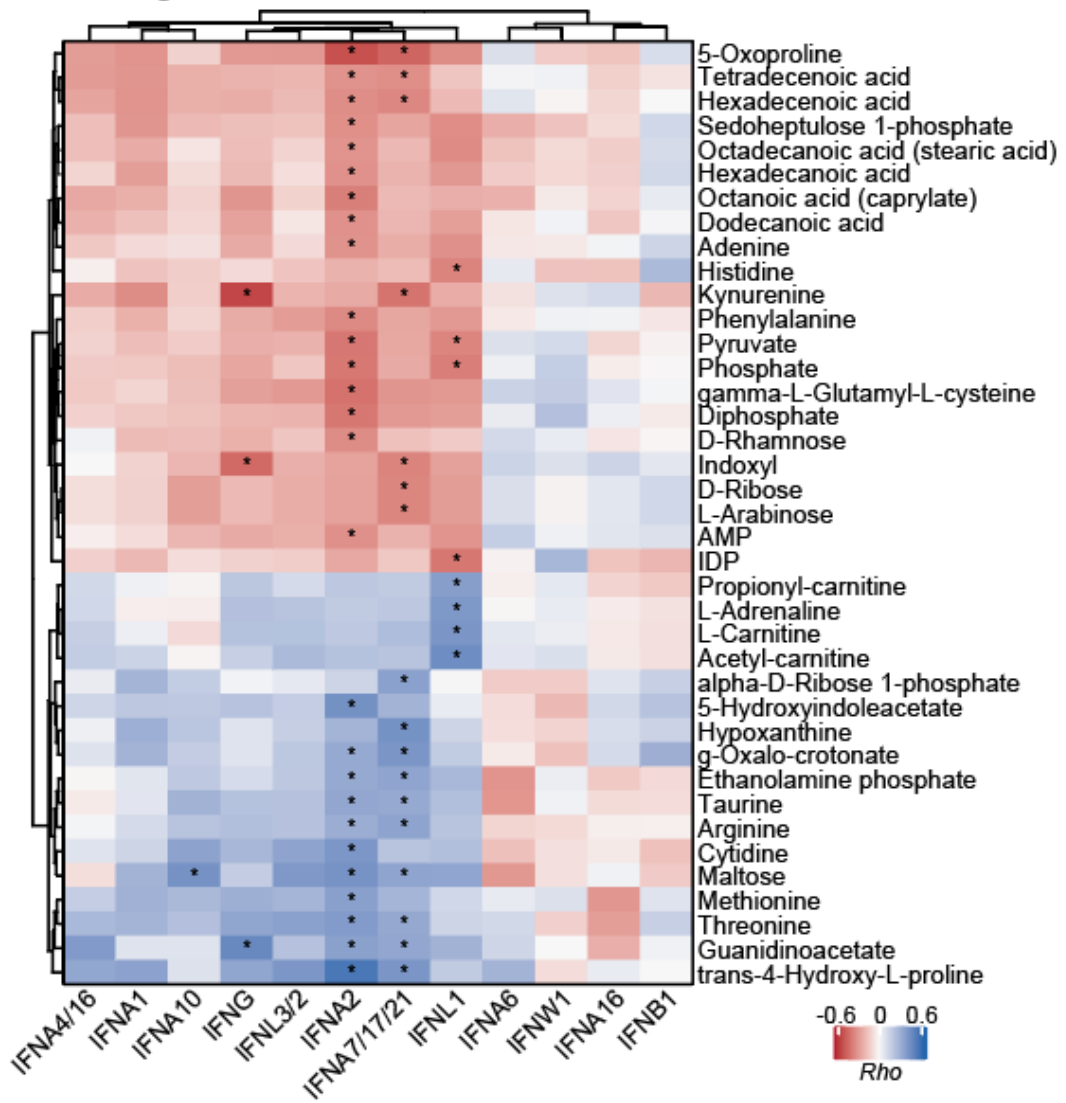

C

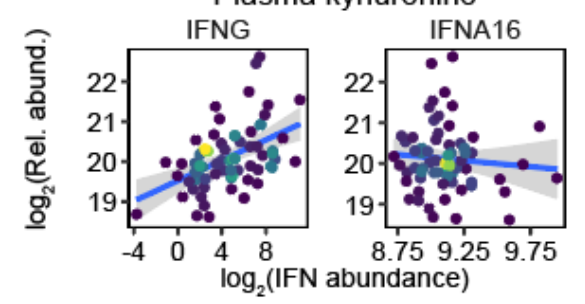

D

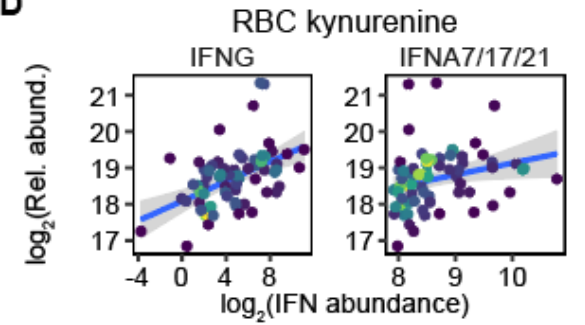

E

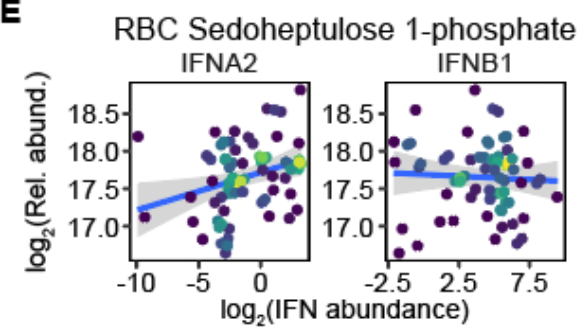

$\mathbf{F}$
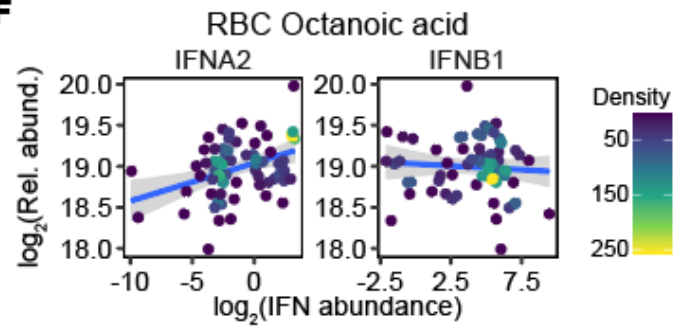

G

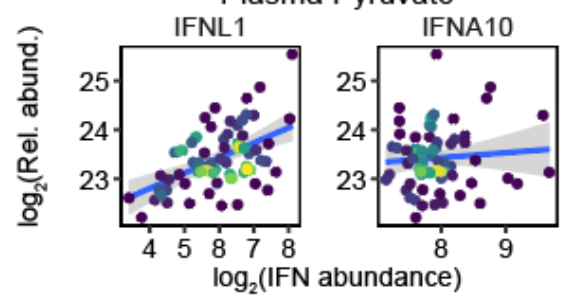

H

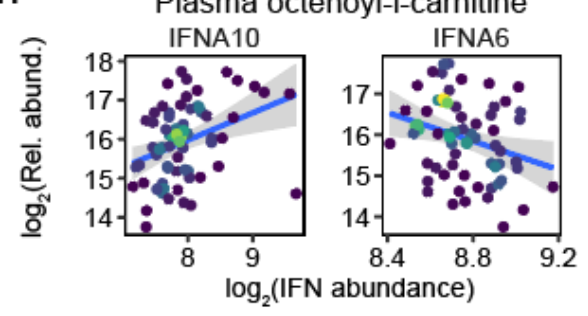

I

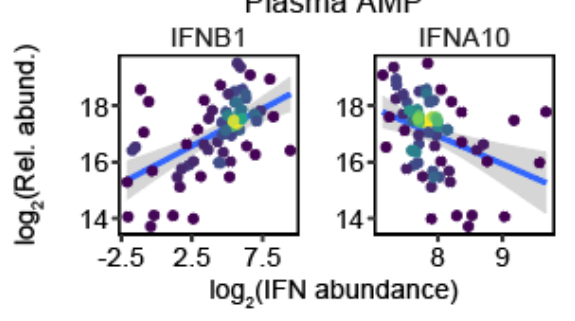

Figure 5 
medRxiv preprint doi: https://doi.org/10.1101/2021.07.29.21261325; this version posted August 1, 2021. The copyright holder for this preprint (which was not certified by peer review) is the author/funder, who has granted medRxiv a license to display the preprint in perpetuity.

It is made available under a CC-BY 4.0 International license.

Figure 5. Differential metabolite signatures associated with IFN ligands. (A-B) Heatmap representing correlations between IFN ligands and plasma (A) or red blood cell (RBC, B) metabolite levels. Only metabolites with at least one significant correlation are shown. Values displayed are Spearman correlation scores (Rho); asterisks indicate significant correlations (10\% FDR); columns and rows are grouped by hierarchical clustering. (C-I) Scatter plots comparing relationships between select metabolites and the indicated IFNs in COVID19-positive patients. Points are colored by density; blue lines represent linear model fit with $95 \%$ confidence intervals in grey. See also Figure $\mathbf{5}$ - supplement 1. 
medRxiv preprint doi: https://doi.org/10.1101/2021.07.29.21261325; this version posted August 1, 2021. The copyright holder for this preprint (which was not certified by peer review) is the author/funder, who has granted medRxiv a license to display the preprint in perpetuity.

It is made available under a CC-BY 4.0 International license.

A

IFN ligands vs. Plasma Metabolites

Figure 5 - supplement 1

IFNA1

IFNA2

IFNA6

IFNA10

IFNA16

IFNA4/16

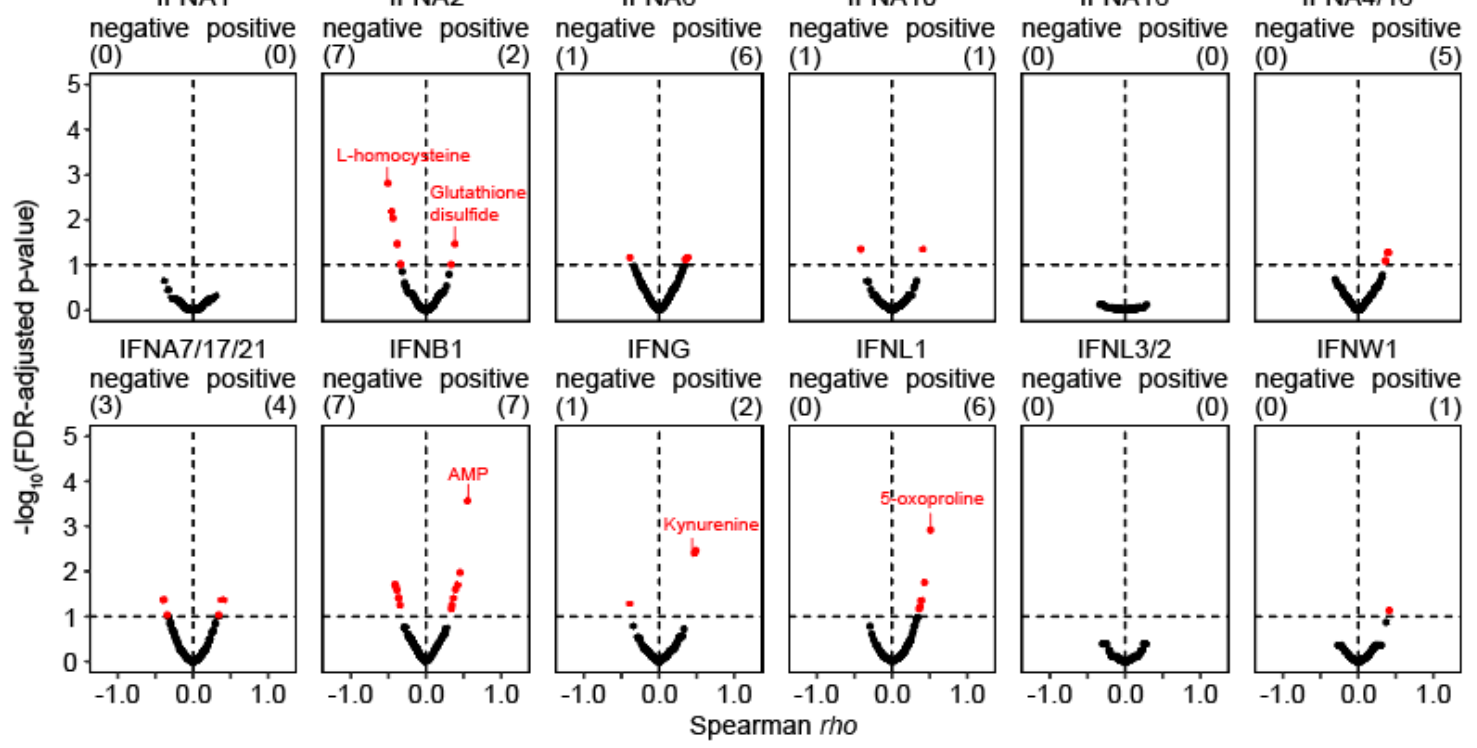

$\mathbf{B}$

IFN ligands vs. Red Blood Cell Metabolites

IFNA6

IFNA10

IFNA16

IFNA4/16
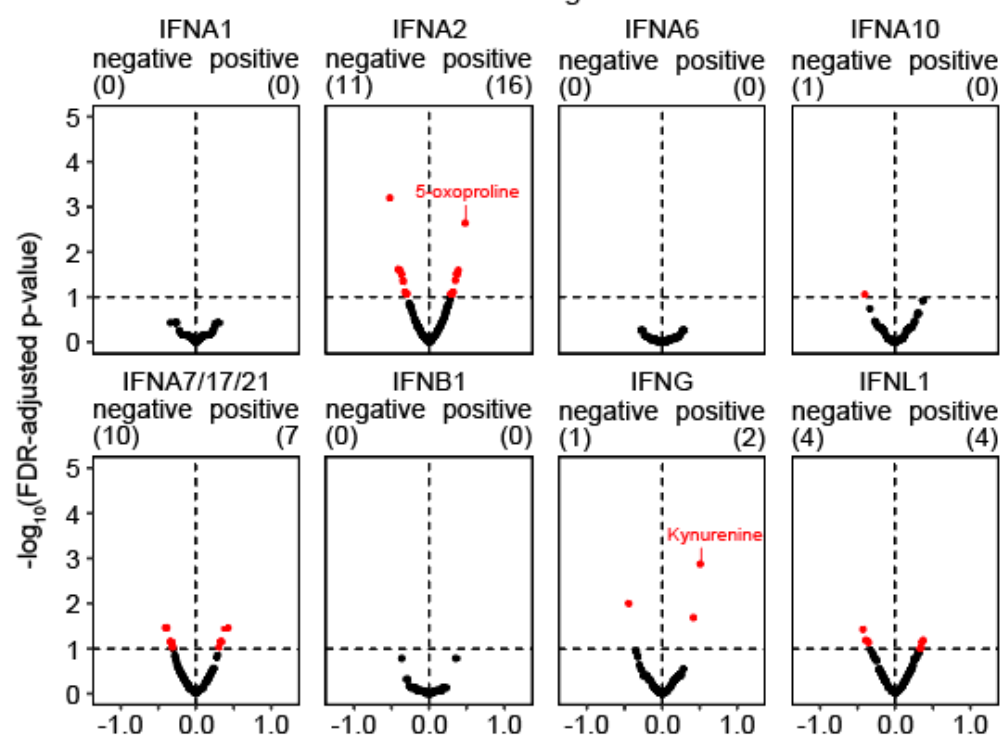

IFNL1

FNG

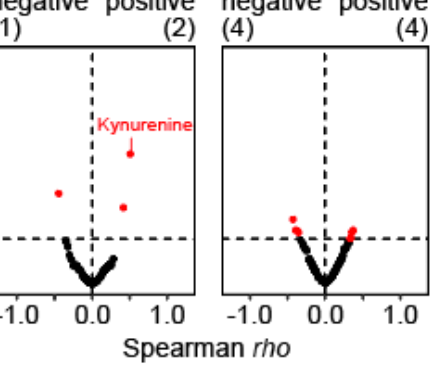

D
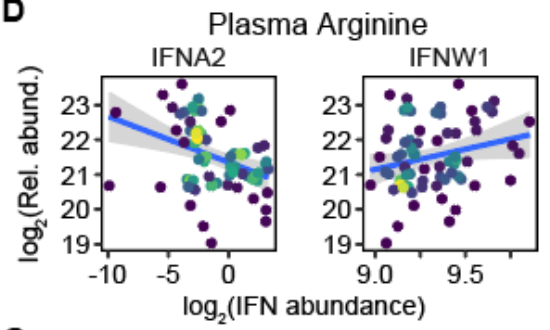

Plasma Cystine

G

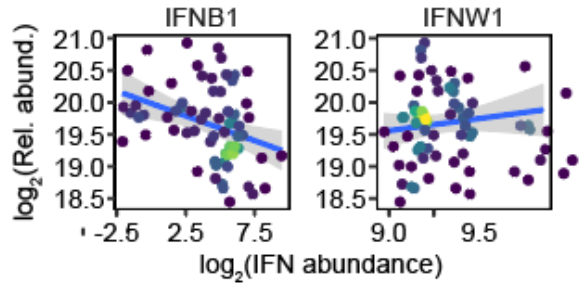

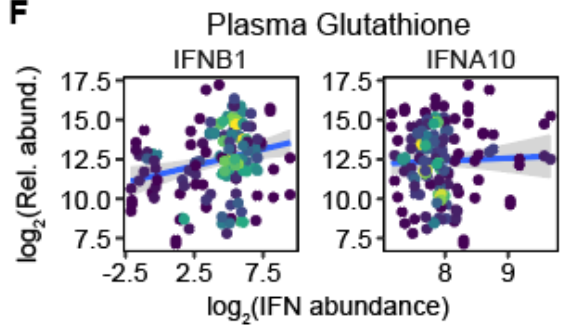

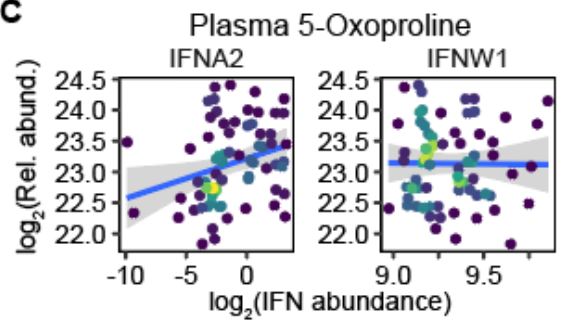

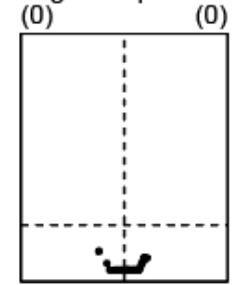

IFNL3/2

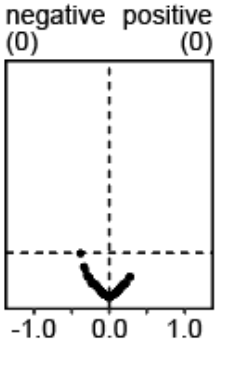

E
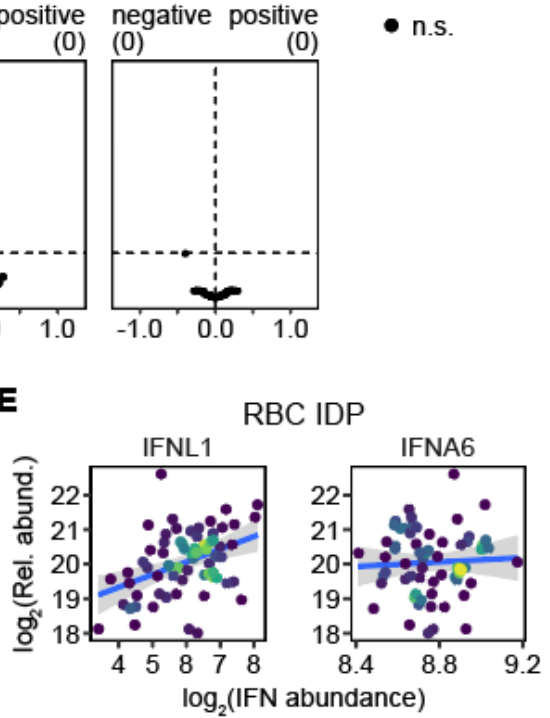

- $\mathrm{q}<0.1$

- n.s.

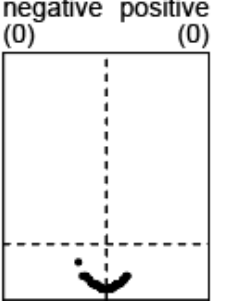

IFNW1 (0)
- $q<0.1$

- n.s. 
medRxiv preprint doi: https://doi.org/10.1101/2021.07.29.21261325; this version posted August 1, 2021. The copyright holder for this preprint (which was not certified by peer review) is the author/funder, who has granted medRxiv a license to display the preprint in perpetuity.

It is made available under a CC-BY 4.0 International license .

Figure 5 - supplement 1. Correlation analysis of plasma and RBC metabolites vs. IFN ligands. (A-B) Volcano plots for Spearman correlation analysis of IFN ligands vs. plasma (A) or RBC (B) metabolite relative abundance values. Horizontal dashed line indicates an FDR threshold of $10 \%(q<$ 0.1 ); red points and numbers above plots indicate significant metabolites at this threshold. (C-G) Scatter plots comparing relationships between select metabolites and the indicated IFNs in COVID19positive patients. Points are colored by density; blue lines represent linear model fit with $95 \%$ confidence intervals in grey. 
medRxiv preprint doi: https://doi.org/10.1101/2021.07.29.21261325; this version posted August 1, 2021. The copyright holder for this preprint (which was not certified by peer review) is the author/funder, who has granted medRxiv a license to display the preprint in perpetuity.

It is made available under a CC-BY 4.0 International license .

\section{DISCUSSION}

IFN signaling is a critical component of the innate immune response and a main driver of the antiviral defense. In the context of viral infections, deficiencies in IFN signaling cause profound susceptibility in humans, as demonstrated by various inborn errors of immunity affecting IFN signaling (41). Despite these clear protective effects, dysregulation of IFN signaling can also contribute to diverse pathologies, as exemplified by Type I Interferonopathies, a group of genetic disorders characterized by chronic overproduction of IFN ligands and severe developmental and clinical phenotypes (42). Furthermore, triplication of the four IFN receptors encoded on chromosome 21 (IFNAR1, IFNAR2, IFNGR2, IL10RB) and consequent IFN hyperactivity in individuals with trisomy 21 are thought to contribute to the developmental and clinical hallmarks of Down syndrome, including their high risk of developing severe COVID19 (43-49). In the context of COVID19, the role of IFN signaling has been the subject of much study and debate, with both protective and deleterious effects being documented in different experimental systems and clinical settings $(2-4,10,14,15)$. Within this framework, we provide here a comprehensive analysis of multi-omics signatures associated with production of multiple IFN ligands in hospitalized COVID19 patients, revealing a high degree of diversity and specialization, even among ligands in the same subfamily.

During vertebrate evolution, the IFN ligand gene family has undergone significant expansion through both tandem gene duplication and retrotransposition events, most likely to accommodate increased regulatory diversity and functional specialization (50). Although modest, our current understanding of IFN ligand specialization is increasing. Functional specialization between major Type I, II and III ligands has been revealed by analysis of genetic mutations affecting specific receptors or downstream kinases and transcription factors in both humans and mice $(41,51)$. For example, it is accepted that deficiencies in IFNG signaling are associated with mycobacterial disease, whereas deficiencies in Type I/III signaling confer susceptibility to viral infections (41). IFN ligand specialization is also evident in the clinical use of recombinant ligands, with IFNB1 being the most effective therapeutic agent for the treatment of multiple sclerosis, whereas IFNA2 preparations are preferred for the treatment of chronic viral infections and some malignancies (52). Despite these advances, little is known about the 
medRxiv preprint doi: https://doi.org/10.1101/2021.07.29.21261325; this version posted August 1, 2021. The copyright holder for this preprint (which was not certified by peer review) is the author/funder, who has granted medRxiv a license to display the preprint in perpetuity.

It is made available under a CC-BY 4.0 International license .

mechanisms behind these differential effects. In this context, our work provides a valuable resource for future mechanistic research. Although our multi-omics analysis is descriptive in nature and based largely on statistically significant associations that should not be interpreted as cause-effect relationships, its value is confirmed by the many associations observed for which mechanisms have already been established. For example, our unbiased analysis of the transcriptome correlations confirmed that 8 of the 12 ligands tested are indeed significantly and positively associated with a transcriptional program highly enriched for ISGs. Likewise, the association between IFNG and metabolites in the kynurenine pathway can be explained by induction of IDO1, a known ISG, during the inflammatory response elicited by SARS-CoV-2 (25-29). Therefore, using these confirmatory observations as reference points, we propose that the datasets described here will help the field elucidate many novel cause-effect relationships explaining IFN ligand specialization.

The specialized biosignatures of IFN ligand action described here could be due to several non-mutually exclusive mechanisms, such as action through different receptors, differences in affinity or allosteric regulation for the same receptors, as well as differences in the location and timing of ligand production. One limitation of our study is that all measurements were performed from peripheral blood, which can only inform about a subset of the pathophysiological processes modulated by the various ligands. Our study would be highly complemented by studies of IFN ligands in various tissues (e.g. (53)). It is also possible that the specialized biosignatures observed are driven in part by SARS-CoV-2 itself. Like other members of the coronavirus family, SARS-CoV-2 has evolved diverse strategies to evade the antiviral effects of IFN signaling, and it is possible that these escape mechanisms do not affect all IFN ligands equally (54). Despite these limitations, key observations produced by our study include the differential relationship between IFN ligands and the antiviral transcriptional program in circulating immune cells, the specialized relationship between seroconversion, immune cell type abundance and IFN ligand levels, and the distinct metabolic signatures associated with the ligands. Throughout the study, the contrast between IFNA2 and IFNA6 exemplifies these points. Both IFNA2 and IFNA6 are specifically recognized by the reagents employed and significantly upregulated in the COVID19 positive cohort. However, whereas IFNA2 is strongly associated with the IFN transcriptional program in immune cells, 
medRxiv preprint doi: https://doi.org/10.1101/2021.07.29.21261325; this version posted August 1, 2021. The copyright holder for this preprint (which was not certified by peer review) is the author/funder, who has granted medRxiv a license to display the preprint in perpetuity.

It is made available under a CC-BY 4.0 International license.

IFNA6 is not. IFNA2 proteomic signatures are enriched for cytokines and chemokines previously linked to IFN signaling, whereas IFNA6 proteomic signatures, similarly to those of IFNB1, are enriched for markers of platelet degranulation. IFNA2 levels decrease with seroconversion, IFNA6 levels do not. Accordingly, IFNA2 abundance associates with increased frequency of various T cell subsets involved in the early antiviral response, while IFNA6 levels correlate with signs of B cell maturation and differentiation. Whereas IFNA2 has the highest number of significant associations in the RBC metabolome of any ligand tested, IFNA6 has none. Therefore, a detailed comparative study of these two IFNA ligands is warranted, including studies in human cell preparations and animal models. In sum, our analyses and datasets provide a rich resource to advance understanding of the IFN ligand family in humans. In order to accelerate the use of these datasets at a global scale, they are made readily available through the COVIDome Explorer Researcher Portal (covidome.org) (17), where users can rapidly recreate the cross-omics correlations described here, investigate any other cross-omics correlations of choice, and download all data for further analysis. 
medRxiv preprint doi: https://doi.org/10.1101/2021.07.29.21261325; this version posted August 1, 2021. The copyright holder for this preprint (which was not certified by peer review) is the author/funder, who has granted medRxiv a license to display the preprint in perpetuity.

It is made available under a CC-BY 4.0 International license .

\section{METHODS}

Study design, participant recruitment, and clinical data capture. Research participants were recruited and consented for participation in the COVID Biobank of the University of Colorado Anschutz Medical Campus [Colorado Multiple Institutional Review Board (COMIRB) Protocol \# 20-0685]. Data was generated from deidentified biospecimens and linked to demographics and clinical metadata procured through the Health Data Compass of the University of Colorado under COMIRB Protocol \# 20-1700. Participants were hospitalized either at Children's Hospital Colorado or the University of Colorado Hospital. COVID status was defined by a positive PCR result and/or antibody test within 14 days of the research blood draw. The control cohort consisted of COVID19-negative research participants receiving medical care for a range of conditions, none of them in critical condition at the time of the research blood draw. Cohort characteristics can be found in Supplementary file 1.

Blood processing. Blood samples were collected into EDTA tubes, sodium heparin tubes, and PAXgene Blood RNA Tubes (PreAnalytiX/Qiagen). After centrifugation, EDTA plasma was used for MS proteomics, SOMAscan ${ }^{\circledR}$ proteomics, as well as multiplex immunoassays using MSD technology for both cytokine profiles and seroconversion assays. From sodium heparin tubes, PBMCs were obtained by the Ficoll gradient method before cryopreservation and assembly of batches for MC analysis (see below).

Whole-blood RNA library preparation and sequencing. RNA was purified from PAXgene Blood RNA Tubes (PreAnalytiX/Qiagen) using a PAXgene Blood RNA Kit (Qiagen), according to the manufacturer's instructions. RNA quality was assessed using an Agilent 2200 TapeStation and quantified by Qubit (Life Technologies). Globin RNA depletion, poly-A(+) RNA enrichment, and strand-specific library preparation were carried out using a Universal Plus mRNA-Seq with NuQuant, Human Globin AnyDeplete (Tecan). Paired-end 150 bp sequencing was carried out on an Illumina NovaSeq 6000 instrument by the Genomics Shared Resource at the University of Colorado Anschutz Medical Campus. 
medRxiv preprint doi: https://doi.org/10.1101/2021.07.29.21261325; this version posted August 1, 2021. The copyright holder for this preprint (which was not certified by peer review) is the author/funder, who has granted medRxiv a license to display the preprint in perpetuity.

It is made available under a CC-BY 4.0 International license .

Plasma proteomics by SOMAscan ${ }^{\circledR}$ assays. $125 \mu$ L EDTA plasma was analyzed by $\operatorname{SOMAscan~}^{\circledR}$ assays using previously established protocols (55). Briefly, each of the 4000+ SOMAmer reagents binds a target peptide and is quantified on a custom Agilent hybridization chip. Normalization and calibration were performed according to SOMAscan ${ }^{\circledR}$ Data Standardization and File Specification Technical Note (SSM-020) (55). The output of the SOMAscan ${ }^{\circledR}$ assay is reported in relative fluorescent units (RFU). Validation of IFN detection was carried out by spiking recombinant human IFN ligands into separate aliquots of a pooled plasma reference sample $(10 \mathrm{pg} / \mu \mathrm{L})$. Data were processed as above and then to account for background signal in the reference sample, the median relative abundance measured by each SOMAscan ${ }^{\circledR}$ aptamer reagent across all samples was subtracted from the corresponding values for each spike-in sample. Recombinant human IFN ligands were obtained from PBL Assay Science (Piscataway, NJ 08854 USA), with the following catalog numbers: 11002-1 (Human Interferon Alpha Sampler Set: IFNA1, IFNA2, IFNA4, IFNA5, IFNA6, IFNA7, IFNA8, IFNA10, IFNA14, IFNA16, IFNA17, IFNA21); 11725-1 (IFNL1); 11720-1 (IFNL2); 11730-1 (IFNL3); 11500-1 (IFNG); 11420-1 (IFNB1).

Cytokine profiling and seroconversion by multiplex immunoassay. Multiplex immunoassays MSD assays were performed on EDTA plasma aliquots following manufacturer's instructions (Meso Scale Discovery, MSD). Absolute values were obtained by extrapolation against a standard curve using provided calibrators. Validation of IFN detection was carried out by spiking a range of concentrations of recombinant IFN ligands into separate aliquots of a pooled plasma reference sample followed by measurement as above. Recombinant human IFN ligands were obtained from PBL Assay Science (Piscataway, NJ 08854 USA), as described above. Seroconversion assays against SARS-CoV-2 proteins were performed in a multiplex immunoassay using the IgG detection readout according to manufacturer's instructions (MSD). Relative values were obtained by extrapolation against a standardized curve consisting of pooled COVID19-positive reference plasma (56). 
medRxiv preprint doi: https://doi.org/10.1101/2021.07.29.21261325; this version posted August 1, 2021. The copyright holder for this preprint (which was not certified by peer review) is the author/funder, who has granted medRxiv a license to display the preprint in perpetuity.

It is made available under a CC-BY 4.0 International license .

Plasma proteomics by mass spectrometry. Plasma samples were digested in S-Trap filters (Protifi, Huntington, NY) according to the manufacturer's procedure. Briefly, a dried protein pellet prepared from organic extraction of patient plasma was solubilized in $400 \mu \mathrm{l}$ of $5 \%(\mathrm{w} / \mathrm{v})$ SDS. Samples were reduced with $10 \mathrm{mM} \mathrm{DTT}$ at $55^{\circ} \mathrm{C}$ for $30 \mathrm{~min}$, cooled to room temperature, and then alkylated with $25 \mathrm{mM}$ iodoacetamide in the dark for $30 \mathrm{~min}$. Next, a final concentration of $1.2 \%$ phosphoric acid and then six volumes of binding buffer [90\% methanol; $100 \mathrm{mM}$ triethylammonium bicarbonate (TEAB); $\mathrm{pH} 7.1]$ were added to each sample. After gentle mixing, the protein solution was loaded into an S-Trap filter, spun at $2000 \mathrm{rpm}$ for $1 \mathrm{~min}$, and the flow-through collected and reloaded onto the filter. This step was repeated three times, and then the filter was washed with $200 \mu \mathrm{L}$ of binding buffer 3 times. Finally, $1 \mu \mathrm{g}$ of sequencing-grade trypsin (Promega) and $150 \mu \mathrm{L}$ of digestion buffer (50 mM TEAB) were added onto the filter and digestion carried out at $47^{\circ} \mathrm{C}$ for $1 \mathrm{~h}$. To elute peptides, three stepwise buffers were applied, $200 \mu \mathrm{L}$ of each with one more repeat, including $50 \mathrm{mM}$ TEAB, $0.2 \%$ formic acid in $\mathrm{H}_{2} \mathrm{O}$, and $50 \%$ acetonitrile and $0.2 \%$ formic acid in $\mathrm{H}_{2} \mathrm{O}$. The peptide solutions were pooled, lyophilized and resuspended in $1 \mathrm{~mL}$ of $0.1 \%$ FA. $20 \mu \mathrm{l}$ of each sample was loaded onto individual Evotips for desalting and then washed with $20 \mu \mathrm{L} 0.1 \%$ FA followed by the addition of $100 \mu \mathrm{L}$ storage solvent $(0.1 \% \mathrm{FA})$ to keep the Evotips wet until analysis. The Evosep One system (Evosep, Odense, Denmark) was used to separate peptides on a Pepsep column, $(150 \mu \mathrm{m}$ internal diameter, $15 \mathrm{~cm})$ packed with ReproSil C18 $1.9 \mu \mathrm{m}, 120 \mathrm{~A}$ resin. The system was coupled to a timsTOF Pro mass spectrometer (Bruker Daltonics, Bremen, Germany) via a nano-electrospray ion source (Captive Spray, Bruker Daltonics). The mass spectrometer was operated in PASEF mode. The ramp time was set to $100 \mathrm{~ms}$ and 10 PASEF MS/MS scans per topN acquisition cycle were acquired. MS and MS/MS spectra were recorded from $\mathrm{m} / \mathrm{z} 100$ to 1700 . The ion mobility was scanned from 0.7 to $1.50 \mathrm{Vs} / \mathrm{cm}^{2}$. Precursors for data-dependent acquisition were isolated within \pm 1 Th and fragmented with an ion mobility-dependent collision energy, which was linearly increased from 20 to $59 \mathrm{eV}$ in positive mode. Low-abundance precursor ions with an intensity above a threshold of 500 counts but below a target value of 20000 counts were repeatedly scheduled and otherwise dynamically excluded for $0.4 \mathrm{~min}$. Raw data file conversion to peak lists in the MGF format, downstream identification, validation, filtering and 
medRxiv preprint doi: https://doi.org/10.1101/2021.07.29.21261325; this version posted August 1, 2021. The copyright holder for this preprint (which was not certified by peer review) is the author/funder, who has granted medRxiv a license to display the preprint in perpetuity.

It is made available under a CC-BY 4.0 International license .

quantification were managed using FragPipe version 13.0. MSFragger version 3.0 was used for database searches against a Human isoform-containing UniProt fasta file (version 08/11/2020) with decoys and common contaminants added. The identification settings were as follows: Trypsin, Specific, with a maximum of 2 missed cleavages, up to 2 isotope errors in precursor selection allowed for, 10.0 ppm as MS1 and 20.0 ppm as MS2 tolerances; fixed modifications: Carbamidomethylation of C (+57.021464 Da), variable modifications: Oxidation of M (+15.994915 Da), Acetylation of protein N-term (+42.010565 Da), Pyrolidone from peptide N-term Q or C (-17.026549 Da). The Philosopher toolkit version 3.2.9 (build 1593192429) was used for filtering of results at the peptide and protein level at 0.01 FDR. Label-free quantification was performed by AUC integration with matching between all runs using lonQuant.

Mass cytometry analysis of immune cell types. Cryopreserved PBMCs were thawed, washed twice with Cell Staining Buffer (CSB) (Fluidigm), and counted with an automated cell counter (Countess II Thermo Fisher Scientific). Extracellular staining on live cells was done in CSB for 30 min at room temperature, in $3-5^{\wedge} 10^{6}$ cells per sample. Cells were washed with $1 \mathrm{X}$ PBS (Fluidigm) and stained with 1 $\mathrm{mL}$ of $0.25 \mathrm{mM}$ cisplatin (Fluidigm) for $1 \mathrm{~min}$ at room temperature for exclusion of dead cells. Samples were then washed with CSB and incubated with 1.6\% PFA (Electron Microscopy Sciences) during 10 min at room temperature. Samples were washed with CBS and barcoded using a Cell-IDTM 20- Plex Pd Barcoding Kit (Fluidigm) of lanthanide-tagged cell reactive metal chelators that will covalently label samples with a unique combination of palladium isotopes, then combined. Surface staining with antibodies that work on fixed epitopes was performed in CSB for $30 \mathrm{~min}$ at room temperature (see Supplementary file 16 for antibody information). Cells were washed twice with CSB and fixed in Fix/Perm buffer (eBioscience) for $30 \mathrm{~min}$, washed in permeabilization buffer (eBioscience) twice, then intracellular factors were stained in permeabilization buffer for $45 \mathrm{~min}$ at $4^{\circ} \mathrm{C}$. Cells were washed twice with Fix/Perm Buffer and were labeled overnight at $4^{\circ} \mathrm{C}$ with Cell-ID Intercalator-Ir (Fluidigm) for DNA staining. Cells were then analyzed on a Helios instrument (Fluidigm). To make all samples comparable, pre-processing of mass cytometry data included normalization within and between batches via 
medRxiv preprint doi: https://doi.org/10.1101/2021.07.29.21261325; this version posted August 1, 2021. The copyright holder for this preprint (which was not certified by peer review) is the author/funder, who has granted medRxiv a license to display the preprint in perpetuity.

It is made available under a CC-BY 4.0 International license.

polystyrene beads embedded with lanthanides as previously described (57). Files were debarcoded using the Matlab DebarcoderTool (58). Then normalization again between batches relative to a reference batch based on technical replicates (59).

\section{Mass spectrometry-based metabolomics of plasma and red blood cells.}

Sample extraction. Samples were thawed on ice and extracted via a modified Folch method (chloroform/methanol/water 8:4:3), which completely inactivates other coronaviruses, such as MERSCoV. Briefly, $20 \mu \mathrm{L}$ of sample was diluted in $130 \mu \mathrm{L}$ of LC-MS grade water, $600 \mu \mathrm{L}$ of ice-cold chloroform/methanol (2:1) was added, and the samples were vortexed for 10 seconds. Samples were then incubated at $4^{\circ} \mathrm{C}$ for 5 minutes, quickly vortexed ( 5 seconds), and centrifuged at $14,000 \mathrm{~g}$ for 10 minutes at $4^{\circ} \mathrm{C}$. The top (i.e., aqueous) phase was transferred to a new tube for metabolomics analysis and flash frozen. The bottom (i.e., organic) phase was transferred to a new tube for lipidomics analysis, then dried under $\mathrm{N}_{2}$ flow.

UHPLC-MS metabolomics. Analyses were performed using a Vanquish UHPLC coupled online to a $Q$ Exactive high resolution mass spectrometer (Thermo Fisher Scientific, Bremen, Germany). Samples (10 uL per injection) were randomized and analyzed in positive and negative electrospray ionization modes (separate runs) using a 5-minute C18 gradient on a Kinetex C18 column (Phenomenex) as described (60). Data were analyzed using Maven (Princeton University, Princeton, NJ, USA) in conjunction with the KEGG database and an in-house standard library.

Biostatistics and bioinformatics analyses. Preprocessing, statistical analysis, and plot generation for all datasets was carried out using R (R 4.0.1 / Rstudio 1.3.959 / Bioconductor v 3.11) (61-63), as detailed below.

Analysis of transcriptome data. RNA-seq data yield was $\sim 40-80 \times 10^{6}$ raw reads and $\sim 32-71 \times 10^{6}$ final mapped reads per sample. Reads were demultiplexed and converted to fastq format using bcl2fastq (bcl2fastq v2.20.0.422). Data quality was assessed using FASTQC (v0.11.5)

(https://www.bioinformatics.babraham.ac.uk/projects/fastqc/) and FastQ Screen (v0.11.0, 
medRxiv preprint doi: https://doi.org/10.1101/2021.07.29.21261325; this version posted August 1, 2021. The copyright holder for this preprint (which was not certified by peer review) is the author/funder, who has granted medRxiv a license to display the preprint in perpetuity.

It is made available under a CC-BY 4.0 International license .

https://www.bioinformatics.babraham.ac.uk/projects/fastq_screen/). Trimming and filtering of low-quality reads was performed using bbduk from BBTools (v37.99)(64) and fastq-mcf from ea-utils (v1.05, https://expressionanalysis.github.io/ea-utils/). Alignment to the human reference genome (GRCh38) was carried out using HISAT2 (v2.1.0)(65) in paired, spliced-alignment mode with a GRCh38 index with a Gencode v33 annotation GTF, and alignments were sorted and filtered for mapping quality (MAPQ > 10) using Samtools (v1.5)(66). Gene-level count data were quantified using HTSeq-count (v0.6.1)(67) with the following options (--stranded=reverse -minaqual=10 -type=exon --mode=intersectionnonempty) using a Gencode v33 GTF annotation file. Differential gene expression in COVID+ versus COVID- was evaluated using DESeq2 (version 1.28.1)(68) in R (version 4.0.1), using $q<0.1$ (FDR < $10 \%)$ as the threshold for differentially expressed genes.

Analysis of SOMAscan ${ }^{\circledR}$ data. Normalized data (RFU) was imported and converted from a SOMAscan ${ }^{\circledR}$ .adat file using a custom R package (SomaDatalO v3.1.0, https://github.com/SomaLogic/SomaDatalO) for use in all subsequent analysis.

Analysis of MSD cytokine profiling data. Plasma concentration values (pg/mL) for each of the cytokines and related immune factors measured across multiple MSD assay plates was imported to R, combined, and analytes with $>10 \%$ of values outside of detection or fit curve range flagged. For each analyte, missing values were replaced with either the minimum (if below fit curve range) or maximum (if above fit curve range) calculated concentration and means of duplicate wells used in all further analysis. Analysis of MS-proteomic data. Raw Razor intensity data were filtered for high abundance proteins by removing those with $>70 \%$ zero values in both COVID19-negative and COVID19-positive groups. For the remaining 407 abundant proteins, 0 values (8,363 missing values of 44,363 total measurements) were replaced with a random value sampled from between 0 and $0.5 x$ the minimum non-zero intensity value for that protein. Data was then normalized using a scaling factor derived from the global median intensity value across all proteins / sample median intensity across all proteins (69).

Analysis of mass cytometry data. MC data was exported as individual FCS files. Within the cytofkit package graphical user interface (v1.11.3) (70), FCS files were imported to R (v4.0.3) using the read.FCS() function from the flowCore package (v2.2.0) (71) and raw intensity values inverse 
medRxiv preprint doi: https://doi.org/10.1101/2021.07.29.21261325; this version posted August 1, 2021. The copyright holder for this preprint (which was not certified by peer review) is the author/funder, who has granted medRxiv a license to display the preprint in perpetuity.

It is made available under a CC-BY 4.0 International license .

hyperbolic sine transformed using the cytofAsinh() function with cofactor $=5$ from the cytofkit package, and 1000 cells per FCS file sampled without replacement for downstream analysis. For visualization, dimensionality reduction was performed using the t-distributed stochastic neighbor embedding (t-SNE) method from the Rtsne package (v0.15) (72), using all markers. Unsupervised clustering, using all markers, was performed using the cytofkit implementation of the PhenoGraph algorithm (22).

Transformed marker expression values for each clustered cell/event were exported and Z-scores calculated across all events for visualization on t-SNE plots. Relative frequencies for each cluster were calculated as proportions of live cells per sample for use in subsequent analyses. For traditionally gated cell subpopulations (gating strategy is described in (16)), relative frequencies were exported from CellEngine as percentages of various parental lineages for use in subsequent analyses.

Analysis of LCMS-metabolomics data. Peak intensity data was imported to R. Across the 171 metabolites, 0 values (486 missing values of 21,033 total measurements) were replaced with a random value sampled from between 0 and $0.5 x$ the minimum non-zero intensity value for that metabolite. For downstream analysis, data was then normalized using a scaling factor derived by dividing the global median intensity value across all proteins by each sample median intensity. Median normalization was chosen as it is simple to employ, relies on few assumptions, and performs on-par with more complex normalization techniques, such as linear regression, local regression, total intensity, average intensity, and quantile normalization, in reducing intragroup variation (73), and is one of the non-reference-based normalization methods employed in the widely-used MetaboAnalyst pre-processing module (74).

Gene Set Enrichment Analysis (GSEA). GSEA (75) was carried out using the fgsea package (v 1.14.0) (76) in R (version 4.0.1), using Hallmark gene sets (18) and either $\log _{2}$-transformed fold-changes (for RNA-seq and Somascan) or Spearman rho values (for IFN correlations) as the ranking metric. Interferon Alpha/Gamma Scores. To capture interferon signaling in each sample as a single value we calculated RNA-seq- or Somascan-based 'Interferon Alpha' and 'Interferon Gamma' scores as follows: Firstly, Z-scores were calculated from the age- and sex-adjusted concentration values for each gene/protein in each sample, based on the mean and standard deviation of COVID19-negative samples. Secondly, per-sample scores were calculated as the sum of Z-scores for genes/proteins in 
medRxiv preprint doi: https://doi.org/10.1101/2021.07.29.21261325; this version posted August 1, 2021. The copyright holder for this preprint (which was not certified by peer review) is the author/funder, who has granted medRxiv a license to display the preprint in perpetuity.

It is made available under a CC-BY 4.0 International license .

the Hallmark Interferon Alpha or Hallmark Interferon Gamma Response gene sets (18), filtered to genes/proteins with significant increases in the COVID-positive group (see next section).

Differential abundance analysis. For RNAseq, gene-level differential expression in COVID+ versus COVID- was evaluated using DESeq2 (version 1.28.1)(68) in R (version 4.0.1), with $q<0.1$ (FDR < $10 \%)$ as the threshold for differentially expressed genes, and considering only genes with $\geq 0.5$ countsper-million in at least two samples. Differential abundance analysis for SOMAscan ${ }^{\circledR}$ proteomics, MSD cytokine profiling, MS proteomics, and LCMS metabolomics was performed using linear models in R (version 4.0.1) with $\log _{2}$ concentration/abundance as the outcome/dependent variable and COVID19 status as the predictor/independent variable, with adjustment for Age and Sex. Multiple hypothesis correction was performed with the Benjamini-Hochberg method using a false discovery rate (FDR) threshold of $10 \%(q<0.1)$.

Correlation analysis. To identify features in each dataset that correlate with plasma levels of the 12 IFN ligands in COVID19 positive samples, Spearman rho values and p-values were calculated against the Sex/Age-adjusted values for each dataset using the rcorr function from the Hmisc package (v 4.4-0) (77), with Benjamini-Hochberg correction of p-values and an estimated FDR threshold of 0.1. For visualization, Heatmaps and XY scatter plots, with points colored by local density using a custom density function, were generated using the ComplexHeatmap (v2.4.2) (78) and the ggplot2 (v3.3.1) (79) packages. Extreme outlier data points (above Q3 + 3xIQR or below Q1 - 3XIQR) were removed. Beta regression analysis of $M C$ data. To identify cell clusters or gated cell subsets for which relative frequencies are associated with plasma levels of the 12 IFN ligands in COVID19 positive samples, beta regression analysis was carried out using the betareg package (v3.1-4) (80), with each model using cell cluster/subset proportions (relative frequency) as the outcome/dependent variable and log2-

transformed IFN abundance values as the independent/predictor variable, with adjustment for Age and Sex, and a logit link function. Effect sizes (as fold-change per unit IFN abundance) for each IFN ligand were obtained by exponentiation of beta regression model coefficients. For comparison across IFN ligands as in volcano plots and heatmaps, beta regression model coefficients were multiplied by the standard deviation of the corresponding ligand before exponentiating to give 'standardized' fold- 
medRxiv preprint doi: https://doi.org/10.1101/2021.07.29.21261325; this version posted August 1, 2021. The copyright holder for this preprint (which was not certified by peer review) is the author/funder, who has granted medRxiv a license to display the preprint in perpetuity.

It is made available under a CC-BY 4.0 International license .

changes per standard deviation of IFN abundance. Standardized fold-changes from each model were visualized by overlaying on t-SNE plots or as heatmaps using the ggplot2 (v3.3.1) (79) and ComplexHeatmap (v2.4.2) (78) packages. For visualization of individual IFN ligand vs. cluster/subset examples, data points were visualized as XY scatter plots, with points colored by local density using a custom function, and overlaid with beta regression fit curves and $95 \%$ confidence intervals extracted from model objects using the ggemmeans() function from the ggeffects package (v1.1.0) (81). 
medRxiv preprint doi: https://doi.org/10.1101/2021.07.29.21261325; this version posted August 1, 2021. The copyright holder for this preprint (which was not certified by peer review) is the author/funder, who has granted medRxiv a license to display the preprint in perpetuity.

It is made available under a CC-BY 4.0 International license.

\section{DATA AVAILABILITY STATEMENT}

Data used in this manuscript are available via the COVIDome Explorer online researcher portal (covidome.org), as described in (17). The RNAseq data have been deposited in NCBI Gene Expression Omnibus, with series accession number GSE167000. The SOMAscan® Proteomics, MSD Cytokine Profiles, and Sample Metadata files have been deposited in Mendeley under entry doi:10.17632/2mc6rrc5j3.2. The mass spectrometry proteomics data have been deposited to the ProteomeXchange Consortium via the PRIDE partner repository (75) with the dataset identifier PXD022817. The mass cytometry data has been deposited in Flow Repository (flowrepository.org) (76) with Repository ID FR-FCM-Z367. Raw metabolomics MS data files and annotated reports are available at the NIH Common Fund's National Metabolomics Data Repository (NMDR) website (supported by NIH grant U2C-DK119886), the Metabolomics Workbench (metabolomicsworkbench.org) under the Project ID PR001110. These data can be accessed directly via the Project DOI: 10.21228/M8739H.

\section{AKNOWLEDGMENTS}

We are grateful to Dr. Thomas Flaig and the Office of the Vice Chancellor for Research (OVCR) at the University of Colorado Anschutz Medical Campus for their leadership in setting up the COVID19 Biobank at the University of Colorado, and also to the COVID19 Biobank Steering Committee for overall support of this project. We thank members of the Biorepository Shared Resource, especially Dr. Adrie Van Bokhoven, Zachary Grasmick, and Hannah Schumman; members of the Human Immune Monitoring Shared Resource, especially Dr. Jill Slansky, Jodi Livesay, Troy Schedin, and Jennifer McWilliams; members of the Flow Cytometry Shared Resource of the University of Colorado Cancer Center, specially Eric Cambley, Alistair Acosta, Christine Childs, and Kristina Terrell; as well as Aaron Issaian for assistance with MS proteomics data analysis. We also thank the SomaLogic team for their support and the Meso Scale Discovery team for generous support with seroconversion assays. We are grateful to Dr. lan Brooks, Michelle Edelmann and the rest of the Health Data Compass team for the clinical data. 
medRxiv preprint doi: https://doi.org/10.1101/2021.07.29.21261325; this version posted August 1, 2021. The copyright holder for this preprint (which was not certified by peer review) is the author/funder, who has granted medRxiv a license to display the preprint in perpetuity.

It is made available under a CC-BY 4.0 International license .

\section{FUNDING STATEMENT}

This work was supported by National Institutes of Health grants R01Al150305 (JME), 3R01Al15030501S1 (JME), R01Al145988 (KDS), UL1TR002535 (TDB), 3UL1TR002535-03S2 (TDB), R01HL146442 (AD), R01HL149714 (AD), R01HL148151 (AD), R21HL150032 (AD), P30CA046934 (JME, KH, AD), R35GM124939 (AAM), RM1GM131968 (AD, KCH), and K23AR070897 (EWYH), as well as grants from the Boettcher Foundation (KDS, EWYH) and Fast Grants (JME). Additional support was received from Chancellor's Discovery Innovation Fund at the CU Anschutz Medical Campus, the Global Down Syndrome Foundation, the Anna and John J. Sie Foundation, the LGA Foundation, and Lyda Hill Philanthropies.

\section{AUTHOR CONTRIBUTIONS}

Conceptualization: MDG, JME, KDS, AAM, TDB, AD, KCH, KRJ, EWYH

Investigation: PA, KPS, REG, RB, KRJ, MD, JAR, FG, FC, TG, AD, KCH

Data curation: MDG, SR, KTK, JRS, TG, RB

Software: MDG, KTK, JRS, TG, RB

Formal Analysis: MDG, KTK, JME, JRS, PA, TG, RB

Visualization: MDG, JME, PA

Funding acquisition: JME, TDB, KCH, AD, KDS, EWYH

Writing - original draft: JME, MDG

Writing - review \& editing: all authors.

\section{DECLARATION OF INTERESTS}

JME serves in the COVID Development Advisory Board for Elly Lilly and has provided consulting services to Gilead Sciences Inc. 
medRxiv preprint doi: https://doi.org/10.1101/2021.07.29.21261325; this version posted August 1, 2021. The copyright holder for this preprint (which was not certified by peer review) is the author/funder, who has granted medRxiv a license to display the preprint in perpetuity.

It is made available under a CC-BY 4.0 International license .

\section{SUPPLEMENTARY FILES LEGENDS}

Supplementary file 1. Cohort characteristics. Table summarizing cohort characteristics. Information pertaining less than $10 \%$ of the cohort is indicated as $<10 \%$ to prevent potential reidentification.

Supplementary file 2. Transcriptome differential expression by COVID status. Results of DESeq2 differential expression analysis of whole blood RNA-seq data in COVID-19-positive vs. -negative samples.

Supplementary file 3. GSEA of transcriptome by COVID status. Results from Gene Set Enrichment Analysis (GSEA) of Hallmark gene sets using RNA-seq fold-change COVID-19-positive vs. negative as the ranking metric.

Supplementary file 4. IFN ligands vs transcriptome correlations. Results of Spearman correlation analysis between plasma levels of IFN ligands and whole blood RNA-seq gene-level expression in COVID-19-positive samples.

Supplementary file 5. GSEA of IFN ligands vs transcriptome correlations. Results from Gene Set Enrichment Analysis (GSEA) of Hallmark gene sets using Spearman correlation scores for IFN ligands vs. whole blood RNA-seq gene-level expression as the ranking metric.

Supplementary file 6. SOMAscan ${ }^{\circledR}$ proteomics differential abundance by COVID status. Results of linear model differential abundance analysis of plasma SOMAscan ${ }^{\circledR}$ proteomics data in COVID-19positive vs. -negative samples.

Supplementary file 7. GSEA of SOMAscan ${ }^{\circledR}$ proteomics by COVID status. Results from Gene Set Enrichment Analysis (GSEA) of Hallmark gene sets using SOMAscan ${ }^{\circledR}$ proteomics fold-change COVID19-positive vs. negative as the ranking metric.

Supplementary file 8. IFN ligands vs SOMAscan ${ }^{\circledR}$ proteomics correlations. Results of Spearman correlation analysis between plasma levels of IFN ligands and SOMAscan ${ }^{\circledR}$ proteomics data in COVID19-positive samples.

Supplementary file 9. GSEA of IFN ligands vs SOMAscan proteomics correlations. Results from Gene Set Enrichment Analysis (GSEA) of Hallmark gene sets using Spearman correlation scores for IFN ligands vs. SOMAscan ${ }^{\circledR}$ proteomics data as the ranking metric. 
medRxiv preprint doi: https://doi.org/10.1101/2021.07.29.21261325; this version posted August 1, 2021. The copyright holder for this preprint (which was not certified by peer review) is the author/funder, who has granted medRxiv a license to display the preprint in perpetuity.

It is made available under a CC-BY 4.0 International license .

Supplementary file 10. MS proteomics differential abundance by COVID status. Results of linear model differential abundance analysis of plasma mass spectrometry (MS) proteomics data in COVID19-positive vs. -negative samples.

Supplementary file 11. IFN ligands vs MS proteomics correlations. Results of Spearman correlation analysis between plasma levels of IFN ligands and mass spectrometry (MS) proteomics data in COVID-19-positive samples.

Supplementary file 12. IFN ligands vs mass cytometry clusters beta regression. Results of beta regression analysis of relative frequency data for PhenoGraph-defined subpopulation clusters against plasma levels of IFN ligands in COVID-19-positive samples.

\section{Supplementary file 13. IFN ligands vs mass cytometry gated subpopulations beta regression.}

Results of beta regression analysis of relative frequency data for cell subpopulations defined by manual gating against plasma levels of IFN ligands in COVID-19-positive samples.

Supplementary file 14. IFN ligands vs plasma metabolomics correlations. Results of Spearman correlation analysis between plasma levels of IFN ligands and plasma metabolomics data in COVID-19positive samples.

Supplementary file 15. IFN ligands vs RBC metabolomics correlations. Results of Spearman correlation analysis between plasma levels of IFN ligands and red blood cell (RBC) metabolomics data in COVID-19-positive samples.

Supplementary file 16. Antibodies used in mass cytometry. List of antibodies used in mass cytometry. Column A indicates the antibody target, column B indicates the element conjugated to the antibody, column $\mathrm{C}$ indicates the mass of the element, column $\mathrm{D}$ indicates the manufacturer, column $\mathrm{E}$ indicates the catalog number, column $\mathrm{F}$ indicates the clone number, and column $\mathrm{G}$ indicates the type of stain protocol used (fixed, live or fixed with permeabilization).

\section{FIGURE SUPPLEMENTS}

Figure 1 - supplement 1 . Whole-blood RNA-based IFN gamma scores and validation of plasma IFN ligand measurements. 
medRxiv preprint doi: https://doi.org/10.1101/2021.07.29.21261325; this version posted August 1, 2021. The copyright holder for this preprint (which was not certified by peer review) is the author/funder, who has granted medRxiv a license to display the preprint in perpetuity.

It is made available under a CC-BY 4.0 International license.

Figure 1 - supplement 2. Correlation analysis and GSEA for IFN ligands vs. whole blood transcriptome.

Figure 2 - supplement 1. Plasma protein-based IFN gamma scores and correlation analysis for IFN ligands vs. SOMAscan ${ }^{\circledR}$ proteomics.

Figure 2 - supplement 2. Relationships between IFN ligands and SOMAscan ${ }^{\circledR}$ plasma proteomics.

Figure 3 -supplement 1. Differential abundance and correlation analysis for MS plasma proteomics.

Figure 3 - supplement 2. Relationships between IFN ligands and MS plasma proteomics.

Figure 4 - supplement 1 . PhenoGraph clustering and beta regression analysis of clustered mass cytometry data against IFN ligands.

Figure 4 - supplement 2. Beta regression analysis of gated mass cytometry data against IFN ligands.

Figure 5 - supplement 1. Correlation analysis of plasma and RBC metabolites vs. IFN ligands. 
medRxiv preprint doi: https://doi.org/10.1101/2021.07.29.21261325; this version posted August 1, 2021. The copyright holder for this preprint (which was not certified by peer review) is the author/funder, who has granted medRxiv a license to display the preprint in perpetuity.

It is made available under a CC-BY 4.0 International license .

\section{REFERENCES}

1. Hadjadj J, Yatim N, Barnabei L, Corneau A, Boussier J, Smith N, Pere H, Charbit B, Bondet V, Chenevier-Gobeaux C, Breillat P, Carlier N, Gauzit R, Morbieu C, Pene F, Marin N, Roche N, Szwebel TA, Merkling SH, Treluyer JM, Veyer D, Mouthon L, Blanc C, Tharaux PL, Rozenberg F, Fischer A, Duffy D, Rieux-Laucat F, Kerneis S, Terrier B. Impaired type I interferon activity and inflammatory responses in severe COVID-19 patients. Science. 2020;369(6504):718-24. Epub 2020/07/15. doi: 10.1126/science.abc6027. PubMed PMID: 32661059; PMCID: PMC7402632.

2. Bastard P, Rosen LB, Zhang Q, Michailidis E, Hoffmann HH, Zhang Y, Dorgham K, Philippot Q, Rosain J, Beziat V, Manry J, Shaw E, Haljasmagi L, Peterson P, Lorenzo L, Bizien L, Trouillet-Assant S, Dobbs K, de Jesus AA, Belot A, Kallaste A, Catherinot E, Tandjaoui-Lambiotte Y, Le Pen J, Kerner G, Bigio B, Seeleuthner Y, Yang R, Bolze A, Spaan AN, Delmonte OM, Abers MS, Aiuti A, Casari G, Lampasona V, Piemonti L, Ciceri F, Bilguvar K, Lifton RP, Vasse M, Smadja DM, Migaud M, Hadjadj J, Terrier B, Duffy D, Quintana-Murci L, van de Beek D, Roussel L, Vinh DC, Tangye SG, Haerynck F, Dalmau D, Martinez-Picado J, Brodin P, Nussenzweig MC, Boisson-Dupuis S, Rodriguez-Gallego C, Vogt G, Mogensen TH, Oler AJ, Gu J, Burbelo PD, Cohen JI, Biondi A, Bettini LR, D'Angio M, Bonfanti P, Rossignol P, Mayaux J, Rieux-Laucat F, Husebye ES, Fusco F, Ursini MV, Imberti L, Sottini A, Paghera S, Quiros-Roldan E, Rossi C, Castagnoli R, Montagna D, Licari A, Marseglia GL, Duval X, Ghosn J, Lab H, Group N-UIRtC, Clinicians C, Clinicians C-S, Imagine CG, French CCSG, Milieu Interieur C, Co VCC, Amsterdam UMCC-B, Effort CHG, Tsang JS, Goldbach-Mansky R, Kisand K, Lionakis MS, Puel A, Zhang SY, Holland SM, Gorochov G, Jouanguy E, Rice CM, Cobat A, Notarangelo LD, Abel L, Su HC, Casanova JL. Autoantibodies against type I IFNs in patients with lifethreatening COVID-19. Science. 2020;370(6515). Epub 2020/09/26. doi: 10.1126/science.abd4585. PubMed PMID: 32972996.

3. Zhang Q, Bastard P, Liu Z, Le Pen J, Moncada-Velez M, Chen J, Ogishi M, Sabli IKD, Hodeib S, Korol C, Rosain J, Bilguvar K, Ye J, Bolze A, Bigio B, Yang R, Arias AA, Zhou Q, Zhang Y, Onodi F, Korniotis S, Karpf L, Philippot Q, Chbihi M, Bonnet-Madin L, Dorgham K, Smith N, Schneider WM, Razooky BS, Hoffmann HH, Michailidis E, Moens L, Han JE, Lorenzo L, Bizien L, Meade P, Neehus 
medRxiv preprint doi: https://doi.org/10.1101/2021.07.29.21261325; this version posted August 1, 2021. The copyright holder for this preprint (which was not certified by peer review) is the author/funder, who has granted medRxiv a license to display the preprint in perpetuity.

It is made available under a CC-BY 4.0 International license .

AL, Ugurbil AC, Corneau A, Kerner G, Zhang P, Rapaport F, Seeleuthner Y, Manry J, Masson C,

Schmitt Y, Schluter A, Le Voyer T, Khan T, Li J, Fellay J, Roussel L, Shahrooei M, Alosaimi MF,

Mansouri D, Al-Saud H, Al-Mulla F, Almourfi F, Al-Muhsen SZ, Alsohime F, Al Turki S, Hasanato R, van de Beek D, Biondi A, Bettini LR, D'Angio M, Bonfanti P, Imberti L, Sottini A, Paghera S, Quiros-Roldan E, Rossi C, Oler AJ, Tompkins MF, Alba C, Vandernoot I, Goffard JC, Smits G, Migeotte I, Haerynck F, Soler-Palacin P, Martin-Nalda A, Colobran R, Morange PE, Keles S, Colkesen F, Ozcelik T, Yasar KK, Senoglu S, Karabela SN, Rodriguez-Gallego C, Novelli G, Hraiech S, Tandjaoui-Lambiotte Y, Duval X, Laouenan C, Clinicians C-S, Clinicians C, Imagine CG, French CCSG, Co VCC, Amsterdam UMCC-B, Effort CHG, Group N-UTCI, Snow AL, Dalgard CL, Milner JD, Vinh DC, Mogensen TH, Marr N, Spaan AN, Boisson B, Boisson-Dupuis S, Bustamante J, Puel A, Ciancanelli MJ, Meyts I, Maniatis T, Soumelis V, Amara A, Nussenzweig M, Garcia-Sastre A, Krammer F, Pujol A, Duffy D, Lifton RP, Zhang SY, Gorochov G, Beziat V, Jouanguy E, Sancho-Shimizu V, Rice CM, Abel L, Notarangelo LD, Cobat A, Su HC, Casanova JL. Inborn errors of type I IFN immunity in patients with life-threatening COVID-19. Science. 2020;370(6515). Epub 2020/09/26. doi: 10.1126/science.abd4570. PubMed PMID: 32972995. 4. Israelow B, Song E, Mao T, Lu P, Meir A, Liu F, Alfajaro MM, Wei J, Dong H, Homer RJ, Ring A, Wilen CB, Iwasaki A. Mouse model of SARS-CoV-2 reveals inflammatory role of type I interferon signaling. The Journal of experimental medicine. 2020;217(12). Epub 2020/08/05. doi:

10.1084/jem.20201241. PubMed PMID: 32750141; PMCID: PMC7401025 with SARS-CoV2 spike Nterminal domain pending; reports, "Unrelated to the subject of the work, I have founded, co-founded, and/or hold equity in biotechnology companies including Simcha Therapeutics, Forty Seven Inc., and ALX Oncology. I have also consulted for Medicenna Therapeutics, a company that licensed patents I invented in immuno-oncology. None of these companies are in the SARS-CoV-2 space or work on infectious disease to my knowledge. Broadly related to the subject of this work, within the past year, I have purchased and disposed shares in Gilead Sciences and Vir Biotechnology, which are working on therapeutics in the coronavirus space. I currently hold no shares in either of those companies." No other disclosures were reported. 
medRxiv preprint doi: https://doi.org/10.1101/2021.07.29.21261325; this version posted August 1, 2021. The copyright holder for this preprint (which was not certified by peer review) is the author/funder, who has granted medRxiv a license to display the preprint in perpetuity.

It is made available under a CC-BY 4.0 International license .

5. Channappanavar R, Fehr AR, Vijay R, Mack M, Zhao J, Meyerholz DK, Perlman S.

Dysregulated Type I Interferon and Inflammatory Monocyte-Macrophage Responses Cause Lethal Pneumonia in SARS-CoV-Infected Mice. Cell host \& microbe. 2016;19(2):181-93. Epub 2016/02/13. doi: 10.1016/j.chom.2016.01.007. PubMed PMID: 26867177; PMCID: PMC4752723.

6. Major J, Crotta S, Llorian M, McCabe TM, Gad HH, Priestnall SL, Hartmann R, Wack A. Type I and III interferons disrupt lung epithelial repair during recovery from viral infection. Science.

2020;369(6504):712-7. Epub 2020/06/13. doi: 10.1126/science.abc2061. PubMed PMID: 32527928; PMCID: PMC7292500.

7. Li C, Luo F, Liu C, Xiong N, Xu Z, Zhang W, Yang M, Wang Y, Liu D, Yu C, Zeng J, Zhang L, Li D, Liu Y, Feng M, Liu R, Mei J, Deng S, Zeng Z, He Y, Liu H, Shi Z, Duan M, Kang D, Liao J, Li W, Liu L. Effect of a genetically engineered interferon-alpha versus traditional interferon-alpha in the treatment of moderate-to-severe COVID-19: a randomised clinical trial. Annals of medicine. 2021;53(1):391-401. Epub 2021/02/24. doi: 10.1080/07853890.2021.1890329. PubMed PMID: 33620016; PMCID: PMC7906612.

8. Kalil AC, Patterson TF, Mehta AK, Tomashek KM, Wolfe CR, Ghazaryan V, Marconi VC, RuizPalacios GM, Hsieh L, Kline S, Tapson V, lovine NM, Jain MK, Sweeney DA, El Sahly HM, Branche AR, Regalado Pineda J, Lye DC, Sandkovsky U, Luetkemeyer AF, Cohen SH, Finberg RW, Jackson PEH, Taiwo B, Paules CI, Arguinchona H, Goepfert P, Ahuja N, Frank M, Oh MD, Kim ES, Tan SY, Mularski RA, Nielsen H, Ponce PO, Taylor BS, Larson L, Rouphael NG, Saklawi Y, Cantos VD, Ko ER, Engemann JJ, Amin AN, Watanabe M, Billings J, Elie MC, Davey RT, Burgess TH, Ferreira J, Green M, Makowski M, Cardoso A, de Bono S, Bonnett T, Proschan M, Deye GA, Dempsey W, Nayak SU, Dodd LE, Beigel JH, Members A-SG. Baricitinib plus Remdesivir for Hospitalized Adults with Covid-19. The New England journal of medicine. 2020. Epub 2020/12/12. doi: 10.1056/NEJMoa2031994. PubMed PMID: 33306283; PMCID: PMC7745180.

9. Pairo-Castineira E, Clohisey S, Klaric L, Bretherick AD, Rawlik K, Pasko D, Walker S, Parkinson N, Fourman MH, Russell CD, Furniss J, Richmond A, Gountouna E, Wrobel N, Harrison D, Wang B, Wu Y, Meynert A, Griffiths F, Oosthuyzen W, Kousathanas A, Moutsianas L, Yang Z, Zhai R, Zheng C, 
medRxiv preprint doi: https://doi.org/10.1101/2021.07.29.21261325; this version posted August 1, 2021. The copyright holder for this preprint (which was not certified by peer review) is the author/funder, who has granted medRxiv a license to display the preprint in perpetuity.

It is made available under a CC-BY 4.0 International license .

Grimes G, Beale R, Millar J, Shih B, Keating S, Zechner M, Haley C, Porteous DJ, Hayward C, Yang J, Knight J, Summers C, Shankar-Hari M, Klenerman P, Turtle L, Ho A, Moore SC, Hinds C, Horby P, Nichol A, Maslove D, Ling L, McAuley D, Montgomery H, Walsh T, Pereira AC, Renieri A, Gen OI, Investigators IC, Initiative C-HG, andMe I, Investigators B, Gen Cl, Shen X, Ponting CP, Fawkes A, Tenesa A, Caulfield M, Scott R, Rowan K, Murphy L, Openshaw PJM, Semple MG, Law A, Vitart V, Wilson JF, Baillie JK. Genetic mechanisms of critical illness in COVID-19. Nature. 2021;591(7848):928. Epub 2020/12/12. doi: 10.1038/s41586-020-03065-y. PubMed PMID: 33307546.

10. Wang N, Zhan Y, Zhu L, Hou Z, Liu F, Song P, Qiu F, Wang X, Zou X, Wan D, Qian X, Wang S, Guo Y, Yu H, Cui M, Tong G, Xu Y, Zheng Z, Lu Y, Hong P. Retrospective Multicenter Cohort Study Shows Early Interferon Therapy Is Associated with Favorable Clinical Responses in COVID-19 Patients. Cell host \& microbe. 2020;28(3):455-64 e2. Epub 2020/07/25. doi:

10.1016/j.chom.2020.07.005. PubMed PMID: 32707096; PMCID: PMC7368656.

11. Pestka S, Krause CD, Walter MR. Interferons, interferon-like cytokines, and their receptors. Immunological reviews. 2004;202:8-32. Epub 2004/11/18. doi: 10.1111/j.0105-2896.2004.00204.x. PubMed PMID: 15546383.

12. Li SF, Gong MJ, Zhao FR, Shao JJ, Xie YL, Zhang YG, Chang HY. Type I Interferons: Distinct Biological Activities and Current Applications for Viral Infection. Cellular physiology and biochemistry : international journal of experimental cellular physiology, biochemistry, and pharmacology. 2018;51(5):2377-96. Epub 2018/12/12. doi: 10.1159/000495897. PubMed PMID: 30537741.

13. Makris S, Paulsen M, Johansson C. Type I Interferons as Regulators of Lung Inflammation. Frontiers in immunology. 2017;8:259-. doi: 10.3389/fimmu.2017.00259. PubMed PMID: 28344581. 14. Park A, Iwasaki A. Type I and Type III Interferons - Induction, Signaling, Evasion, and Application to Combat COVID-19. Cell host \& microbe. 2020;27(6):870-8. Epub 2020/05/29. doi: 10.1016/j.chom.2020.05.008. PubMed PMID: 32464097; PMCID: PMC7255347.

15. Schreiber G. The Role of Type I Interferons in the Pathogenesis and Treatment of COVID-19. Front Immunol. 2020;11:595739. Epub 2020/10/30. doi: 10.3389/fimmu.2020.595739. PubMed PMID: 33117408; PMCID: PMC7561359. 
medRxiv preprint doi: https://doi.org/10.1101/2021.07.29.21261325; this version posted August 1, 2021. The copyright holder for this preprint (which was not certified by peer review) is the author/funder, who has granted medRxiv a license to display the preprint in perpetuity.

It is made available under a CC-BY 4.0 International license .

16. Galbraith MD, Kinning KT, Sullivan KD, Baxter R, Araya P, Jordan KR, Russell S, Smith KP, Granrath RE, Shaw JR, Dzieciatkowska M, Ghosh T, Monte AA, D'Alessandro A, Hansen KC, Benett TD, Hsieh EW, Espinosa JM. Seroconversion stages COVID19 into distinct pathophysiological states. Elife. 2021;10. Epub 2021/03/17. doi: 10.7554/eLife.65508. PubMed PMID: 33724185; PMCID: PMC7963480.

17. Sullivan KD, Galbraith MD, Kinning KT, Bartsch K, Levinsky N, Araya P, Smith KP, Granrath RE, Shaw JR, Baxter R, Jordan KR, Russell S, Dzieciatkowska M, Reisz JA, Gamboni F, Cendali F, Ghosh T, Monte AA, Bennett TD, Miller MG, Hsieh EWY, D'Alessandro A, Hansen KC, Espinosa JM. The COVIDome Explorer Researcher Portal. medRxiv. 2021. Epub 2021/03/25. doi:

10.1101/2021.03.04.21252945. PubMed PMID: 33758879; PMCID: PMC7987038.

18. Liberzon A, Birger C, Thorvaldsdottir H, Ghandi M, Mesirov JP, Tamayo P. The Molecular Signatures Database (MSigDB) hallmark gene set collection. Cell Syst. 2015;1(6):417-25. doi: 10.1016/j.cels.2015.12.004. PubMed PMID: 26771021; PMCID: PMC4707969.

19. Gersemann M, Becker S, Nuding S, Antoni L, Ott G, Fritz P, Oue N, Yasui W, Wehkamp J, Stange EF. Olfactomedin-4 is a glycoprotein secreted into mucus in active IBD. J Crohns Colitis. 2012;6(4):425-34. Epub 2012/03/09. doi: 10.1016/j.crohns.2011.09.013. PubMed PMID: 22398066. 20. Raybould MIJ, Kovaltsuk A, Marks C, Deane CM. CoV-AbDab: the coronavirus antibody database. Bioinformatics. 2021;37(5):734-5. Epub 2020/08/18. doi: 10.1093/bioinformatics/btaa739. PubMed PMID: 32805021; PMCID: PMC7558925.

21. Chi X, Yan R, Zhang J, Zhang G, Zhang Y, Hao M, Zhang Z, Fan P, Dong Y, Yang Y, Chen Z, Guo Y, Zhang J, Li Y, Song X, Chen Y, Xia L, Fu L, Hou L, Xu J, Yu C, Li J, Zhou Q, Chen W. A neutralizing human antibody binds to the N-terminal domain of the Spike protein of SARS-CoV-2. Science. 2020;369(6504):650-5. Epub 2020/06/24. doi: 10.1126/science.abc6952. PubMed PMID: 32571838; PMCID: PMC7319273.

22. Levine JH, Simonds EF, Bendall SC, Davis KL, Amir el AD, Tadmor MD, Litvin O, Fienberg HG, Jager A, Zunder ER, Finck R, Gedman AL, Radtke I, Downing JR, Pe'er D, Nolan GP. Data-Driven Phenotypic Dissection of AML Reveals Progenitor-like Cells that Correlate with Prognosis. Cell. 
medRxiv preprint doi: https://doi.org/10.1101/2021.07.29.21261325; this version posted August 1, 2021. The copyright holder for this preprint (which was not certified by peer review) is the author/funder, who has granted medRxiv a license to display the preprint in perpetuity.

It is made available under a CC-BY 4.0 International license .

2015;162(1):184-97. Epub 2015/06/23. doi: 10.1016/j.cell.2015.05.047. PubMed PMID: 26095251;

PMCID: PMC4508757.

23. van der Maaten L, Hinton G. Visualizing High-Dimensional Data Using t-SNE. Journal of Machine Learning Research 2008;9(Nov):2579-605.

24. van der Maaten L. Accelerating t-SNE using Tree-Based Algorithms. Journal of Machine Learning Research. 2014;15(Oct):3221-45.

25. Thomas T, Stefanoni D, Reisz JA, Nemkov T, Bertolone L, Francis RO, Hudson KE, Zimring JC, Hansen KC, Hod EA, Spitalnik SL, D'Alessandro A. COVID-19 infection alters kynurenine and fatty acid metabolism, correlating with IL-6 levels and renal status. JCI insight. 2020;5(14). Epub 2020/06/20. doi: 10.1172/jci.insight.140327. PubMed PMID: 32559180; PMCID: PMC7453907.

26. Cai Y, Kim DJ, Takahashi T, Broadhurst DI, Yan H, Ma S, Rattray NJW, Casanovas-Massana A, Israelow B, Klein J, Lucas C, Mao T, Moore AJ, Muenker MC, Oh JE, Silva J, Wong P, Yale IRt, Ko Al, Khan SA, Iwasaki A, Johnson $\mathrm{CH}$. Kynurenic acid may underlie sex-specific immune responses to COVID-19. Sci Signal. 2021;14(690). Epub 2021/07/08. doi: 10.1126/scisignal.abf8483. PubMed PMID: 34230210.

27. D'Alessandro A, Akpan I, Thomas T, Reisz J, Cendali F, Gamboni F, Nemkov T, Thangaraju K, Katneni U, Tanaka K, Kahn S, Wei A, Valk J, Hudson K, Roh D, Moriconi C, Zimring J, Hod E, Spitalnik S, Buehler P, Francis R. Biological and Clinical Factors contributing to the Metabolic Heterogeneity of Hospitalized Patients with and without COVID-19. Res Sq. 2021. Epub 2021/05/21. doi:

10.21203/rs.3.rs-480167/v1. PubMed PMID: 34013258; PMCID: PMC8132252.

28. Lawler NG, Gray N, Kimhofer T, Boughton B, Gay M, Yang R, Morillon AC, Chin ST, Ryan M, Begum S, Bong SH, Coudert JD, Edgar D, Raby E, Pettersson S, Richards T, Holmes E, Whiley L, Nicholson JK. Systemic Perturbations in Amine and Kynurenine Metabolism Associated with Acute SARS-CoV-2 Infection and Inflammatory Cytokine Responses. J Proteome Res. 2021;20(5):2796-811. Epub 2021/03/17. doi: 10.1021/acs.jproteome.1c00052. PubMed PMID: 33724837; PMCID: PMC7986977. 
medRxiv preprint doi: https://doi.org/10.1101/2021.07.29.21261325; this version posted August 1, 2021. The copyright holder for this preprint (which was not certified by peer review) is the author/funder, who has granted medRxiv a license to display the preprint in perpetuity.

It is made available under a CC-BY 4.0 International license .

29. Lionetto L, Ulivieri M, Capi M, De Bernardini D, Fazio F, Petrucca A, Pomes LM, De Luca O, Gentile G, Casolla B, Curto M, Salerno G, Schillizzi S, Torre MS, Santino I, Rocco M, Marchetti P, Aceti A, Ricci A, Bonfini R, Nicoletti F, Simmaco M, Borro M. Increased kynurenine-to-tryptophan ratio in the serum of patients infected with SARS-CoV2: An observational cohort study. Biochim Biophys Acta Mol Basis Dis. 2021;1867(3):166042. Epub 2020/12/19. doi: 10.1016/j.bbadis.2020.166042. PubMed PMID: 33338598; PMCID: PMC7834629.

30. Zhai L, Spranger S, Binder DC, Gritsina G, Lauing KL, Giles FJ, Wainwright DA. Molecular Pathways: Targeting IDO1 and Other Tryptophan Dioxygenases for Cancer Immunotherapy. Clinical cancer research : an official journal of the American Association for Cancer Research. 2015;21(24):5427-33. doi: 10.1158/1078-0432.CCR-15-0420. PubMed PMID: 26519060; PMCID: 4681601.

31. Fisher AB. The phospholipase A2 activity of peroxiredoxin 6. J Lipid Res. 2018;59(7):1132-47. Epub 2018/05/03. doi: 10.1194/jlr.R082578. PubMed PMID: 29716959; PMCID: PMC6027911. 32. Liebscher S, Ambrose RL, Aktepe TE, Mikulasova A, Prier JE, Gillespie LK, Lopez-Denman AJ, Rupasinghe TWT, Tull D, McConville MJ, Mackenzie JM. Phospholipase A2 activity during the replication cycle of the flavivirus West Nile virus. PLoS pathogens. 2018;14(4):e1007029. Epub 2018/05/01. doi: 10.1371/journal.ppat.1007029. PubMed PMID: 29709018; PMCID: PMC5945048. 33. Zadori Z, Szelei J, Lacoste MC, Li Y, Gariepy S, Raymond P, Allaire M, Nabi IR, Tijssen P. A viral phospholipase A2 is required for parvovirus infectivity. Dev Cell. 2001;1(2):291-302. Epub 2001/11/13. doi: 10.1016/s1534-5807(01)00031-4. PubMed PMID: 11702787.

34. Thomas T, Stefanoni D, Dzieciatkowska M, Issaian A, Nemkov T, Hill RC, Francis RO, Hudson KE, Buehler PW, Zimring JC, Hod EA, Hansen KC, Spitalnik SL, D'Alessandro A. Evidence for structural protein damage and membrane lipid remodeling in red blood cells from COVID-19 patients. medRxiv. 2020. Epub 2020/07/09. doi: 10.1101/2020.06.29.20142703. PubMed PMID: 32637980; PMCID: PMC7340206.

35. Thomas T, Cendali F, Fu X, Gamboni F, Morrison EJ, Beirne J, Nemkov T, Antonelou MH, Kriebardis A, Welsby I, Hay A, Dziewulska KH, Busch MP, Kleinman S, Buehler PW, Spitalnik SL, 
medRxiv preprint doi: https://doi.org/10.1101/2021.07.29.21261325; this version posted August 1, 2021. The copyright holder for this preprint (which was not certified by peer review) is the author/funder, who has granted medRxiv a license to display the preprint in perpetuity.

It is made available under a CC-BY 4.0 International license .

Zimring JC, D'Alessandro A. Fatty acid desaturase activity in mature red blood cells and implications for blood storage quality. Transfusion. 2021. Epub 2021/04/28. doi: 10.1111/trf.16402. PubMed PMID: 33904180.

36. D'Alessandro A, Hay A, Dzieciatkowska M, Brown BC, Morrison EJ, Hansen KC, Zimring JC. Protein-L-isoaspartate O-methyltransferase is required for $<i>$ in vivo</i> control of oxidative damage in red blood cells. Haematologica. 2020;Online ahead of print. Epub 2020/10/16. doi:

10.3324/haematol.2020.266676. PubMed PMID: 33054131.

37. Nemkov T, Skinner SC, Nader E, Stefanoni D, Robert M, Cendali F, Stauffer E, Cibiel A, Boisson C, Connes P, D'Alessandro A. Acute Cycling Exercise Induces Changes in Red Blood Cell Deformability and Membrane Lipid Remodeling. International journal of molecular sciences. 2021;22(2). Epub 2021/01/23. doi: 10.3390/ijms22020896. PubMed PMID: 33477427; PMCID: PMC7831009. 38. Alexander K, Hazegh K, Fang F, Sinchar D, Kiss JE, Page GP, D'Alessandro A, Kanias T. Testosterone replacement therapy in blood donors modulates erythrocyte metabolism and susceptibility to hemolysis in cold storage. Transfusion. 2021;61(1):108-23. Epub 2020/10/20. doi: 10.1111/trf.16141. PubMed PMID: 33073382; PMCID: PMC7902463.

39. Deguchi H, Banerjee Y, Trauger S, Siuzdak G, Kalisiak E, Fernandez JA, Hoang L, Tran M, Yegneswaran S, Elias DJ, Griffin JH. Acylcarnitines are anticoagulants that inhibit factor Xa and are reduced in venous thrombosis, based on metabolomics data. Blood. 2015;126(13):1595-600. Epub 2015/07/16. doi: 10.1182/blood-2015-03-636761. PubMed PMID: 26175037; PMCID: PMC4582336. 40. D'Alessandro A, Thomas T, Dzieciatkowska M, Hill RC, Francis RO, Hudson KE, Zimring JC, Hod EA, Spitalnik SL, Hansen KC. Serum Proteomics in COVID-19 Patients: Altered Coagulation and Complement Status as a Function of IL-6 Level. J Proteome Res. 2020. Epub 2020/08/14. doi: 10.1021/acs.jproteome.0c00365. PubMed PMID: 32786691.

41. Zhang SY, Boisson-Dupuis S, Chapgier A, Yang K, Bustamante J, Puel A, Picard C, Abel L, Jouanguy E, Casanova JL. Inborn errors of interferon (IFN)-mediated immunity in humans: insights into the respective roles of IFN-alpha/beta, IFN-gamma, and IFN-lambda in host defense. Immunological 
medRxiv preprint doi: https://doi.org/10.1101/2021.07.29.21261325; this version posted August 1, 2021. The copyright holder for this preprint (which was not certified by peer review) is the author/funder, who has granted medRxiv a license to display the preprint in perpetuity.

It is made available under a CC-BY 4.0 International license .

reviews. 2008;226:29-40. Epub 2009/01/24. doi: 10.1111/j.1600-065X.2008.00698.x. PubMed PMID: 19161414.

42. Rodero MP, Crow YJ. Type I interferon-mediated monogenic autoinflammation: The type I interferonopathies, a conceptual overview. The Journal of experimental medicine. 2016;213(12):252738. doi: 10.1084/jem.20161596. PubMed PMID: 27821552; PMCID: 5110029.

43. Sullivan KD, Lewis HC, Hill AA, Pandey A, Jackson LP, Cabral JM, Smith KP, Liggett LA, Gomez EB, Galbraith MD, DeGregori J, Espinosa JM. Trisomy 21 consistently activates the interferon response. Elife. 2016;5. Epub 2016/07/30. doi: 10.7554/eLife.16220. PubMed PMID: 27472900; PMCID: PMC5012864.

44. Araya P, Waugh KA, Sullivan KD, Nunez NG, Roselli E, Smith KP, Granrath RE, Rachubinski AL, Enriquez Estrada B, Butcher ET, Minter R, Tuttle KD, Bruno TC, Maccioni M, Espinosa JM. Trisomy 21 dysregulates $T$ cell lineages toward an autoimmunity-prone state associated with interferon hyperactivity. Proc Natl Acad Sci U S A. 2019;116(48):24231-41. Epub 2019/11/09. doi:

10.1073/pnas.1908129116. PubMed PMID: 31699819.

45. Powers RK, Culp-Hill R, Ludwig MP, Smith KP, Waugh KA, Minter R, Tuttle KD, Lewis HC, Rachubinski AL, Granrath RE, Carmona-Iragui M, Wilkerson RB, Kahn DE, Joshi M, Lleo A, Blesa R, Fortea J, D'Alessandro A, Costello JC, Sullivan KD, Espinosa JM. Trisomy 21 activates the kynurenine pathway via increased dosage of interferon receptors. Nat Commun. 2019;10(1):4766. Epub 2019/10/20. doi: 10.1038/s41467-019-12739-9. PubMed PMID: 31628327; PMCID: PMC6800452. 46. Waugh KA, Araya P, Pandey A, Jordan KR, Smith KP, Granrath RE, Khanal S, Butcher ET, Estrada BE, Rachubinski AL, McWilliams JA, Minter R, Dimasi T, Colvin KL, Baturin D, Pham AT, Galbraith MD, Bartsch KW, Yeager ME, Porter CC, Sullivan KD, Hsieh EW, Espinosa JM. Mass Cytometry Reveals Global Immune Remodeling with Multi-lineage Hypersensitivity to Type I Interferon in Down Syndrome. Cell reports. 2019;29(7):1893-908 e4. Epub 2019/11/14. doi:

10.1016/j.celrep.2019.10.038. PubMed PMID: 31722205; PMCID: PMC6871766. 
medRxiv preprint doi: https://doi.org/10.1101/2021.07.29.21261325; this version posted August 1, 2021. The copyright holder for this preprint (which was not certified by peer review) is the author/funder, who has granted medRxiv a license to display the preprint in perpetuity.

It is made available under a CC-BY 4.0 International license .

47. Espinosa JM. Down Syndrome and COVID-19: A Perfect Storm? Cell Rep Med.

2020;1(2):100019. Epub 2020/06/06. doi: 10.1016/j.xcrm.2020.100019. PubMed PMID: 32501455;

PMCID: PMC7252041 attenuate the cytokine storm in COVID-19.

48. Kong XF, Worley L, Rinchai D, Bondet V, Jithesh PV, Goulet M, Nonnotte E, Rebillat AS, Conte M, Mircher C, Gurtler N, Liu L, Migaud M, Elanbari M, Habib T, Ma CS, Bustamante J, Abel L, Ravel A, Lyonnet S, Munnich A, Duffy D, Chaussabel D, Casanova JL, Tangye SG, Boisson-Dupuis S, Puel A. Three Copies of Four Interferon Receptor Genes Underlie a Mild Type I Interferonopathy in Down Syndrome. J Clin Immunol. 2020;40(6):807-19. Epub 2020/06/24. doi: 10.1007/s10875-020-00803-9. PubMed PMID: 32572726; PMCID: PMC7418179.

49. Tuttle KD, Waugh KA, Araya P, Minter R, Orlicky DJ, Ludwig M, Andrysik Z, Burchill MA, Tamburini BAJ, Sempeck C, Smith K, Granrath R, Tracy D, Baxter J, Espinosa JM, Sullivan KD. JAK1 Inhibition Blocks Lethal Immune Hypersensitivity in a Mouse Model of Down Syndrome. Cell reports. 2020;33(7):108407. Epub 2020/11/19. doi: 10.1016/j.celrep.2020.108407. PubMed PMID: 33207208. 50. Secombes CJ, Zou J. Evolution of Interferons and Interferon Receptors. Front Immunol. 2017;8:209. Epub 2017/03/18. doi: 10.3389/fimmu.2017.00209. PubMed PMID: 28303139; PMCID: PMC5332411.

51. de Weerd NA, Nguyen T. The interferons and their receptors--distribution and regulation. Immunology and cell biology. 2012;90(5):483-91. Epub 2012/03/14. doi: 10.1038/icb.2012.9. PubMed PMID: 22410872.

52. Borden EC, Sen GC, Uze G, Silverman RH, Ransohoff RM, Foster GR, Stark GR. Interferons at age 50: past, current and future impact on biomedicine. Nature reviews Drug discovery. 2007;6(12):975-90. Epub 2007/12/01. doi: 10.1038/nrd2422. PubMed PMID: 18049472; PMCID: PMC7097588.

53. Delorey TM, Ziegler CGK, Heimberg G, Normand R, Yang Y, Segerstolpe A, Abbondanza D, Fleming SJ, Subramanian A, Montoro DT, Jagadeesh KA, Dey KK, Sen P, Slyper M, Pita-Juarez YH, Phillips D, Biermann J, Bloom-Ackermann Z, Barkas N, Ganna A, Gomez J, Melms JC, Katsyv I, Normandin E, Naderi P, Popov YV, Raju SS, Niezen S, Tsai LT, Siddle KJ, Sud M, Tran VM, Vellarikkal 
medRxiv preprint doi: https://doi.org/10.1101/2021.07.29.21261325; this version posted August 1, 2021. The copyright holder for this preprint (which was not certified by peer review) is the author/funder, who has granted medRxiv a license to display the preprint in perpetuity.

It is made available under a CC-BY 4.0 International license .

SK, Wang Y, Amir-Zilberstein L, Atri DS, Beechem J, Brook OR, Chen J, Divakar P, Dorceus P, Engreitz JM, Essene A, Fitzgerald DM, Fropf R, Gazal S, Gould J, Grzyb J, Harvey T, Hecht J, Hether T, Jane-Valbuena J, Leney-Greene M, Ma H, McCabe C, McLoughlin DE, Miller EM, Muus C, Niemi M, Padera R, Pan L, Pant D, Pe'er C, Pfiffner-Borges J, Pinto CJ, Plaisted J, Reeves J, Ross M, Rudy M, Rueckert EH, Siciliano M, Sturm A, Todres E, Waghray A, Warren S, Zhang S, Zollinger DR, Cosimi L, Gupta RM, Hacohen N, Hibshoosh H, Hide W, Price AL, Rajagopal J, Tata PR, Riedel S, Szabo G, Tickle TL, Ellinor PT, Hung D, Sabeti PC, Novak R, Rogers R, Ingber DE, Jiang ZG, Juric D, Babadi M, Farhi SL, Izar B, Stone JR, Vlachos IS, Solomon IH, Ashenberg O, Porter CBM, Li B, Shalek AK, Villani AC, Rozenblatt-Rosen O, Regev A. COVID-19 tissue atlases reveal SARS-CoV-2 pathology and cellular targets. Nature. 2021;595(7865):107-13. Epub 2021/04/30. doi: 10.1038/s41586-021-03570-8. PubMed PMID: 33915569.

54. Lei X, Dong X, Ma R, Wang W, Xiao X, Tian Z, Wang C, Wang Y, Li L, Ren L, Guo F, Zhao Z, Zhou Z, Xiang Z, Wang J. Activation and evasion of type I interferon responses by SARS-CoV-2. Nat Commun. 2020;11(1):3810. Epub 2020/08/01. doi: 10.1038/s41467-020-17665-9. PubMed PMID: 32733001; PMCID: PMC7392898.

55. Gold L, Walker JJ, Wilcox SK, Williams S. Advances in human proteomics at high scale with the SOMAscan proteomics platform. N Biotechnol. 2012;29(5):543-9. doi: 10.1016/j.nbt.2011.11.016.

PubMed PMID: 22155539.

56. Johnson M, Wagstaffe HR, Gilmour KC, Mai AL, Lewis J, Hunt A, Sirr J, Bengt C, Grandjean L, Goldblatt D. Evaluation of a novel multiplexed assay for determining lgG levels and functional activity to SARS-CoV-2. J Clin Virol. 2020;130:104572. Epub 2020/08/10. doi: 10.1016/j.jcv.2020.104572.

PubMed PMID: 32769024; PMCID: PMC7396134.

57. Finck R, Simonds EF, Jager A, Krishnaswamy S, Sachs K, Fantl W, Pe'er D, Nolan GP, Bendall SC. Normalization of mass cytometry data with bead standards. Cytometry A. 2013;83(5):483-94. Epub 2013/03/21. doi: 10.1002/cyto.a.22271. PubMed PMID: 23512433; PMCID: PMC3688049.

58. Zunder ER, Finck R, Behbehani GK, Amir el AD, Krishnaswamy S, Gonzalez VD, Lorang CG, Bjornson Z, Spitzer MH, Bodenmiller B, Fantl WJ, Pe'er D, Nolan GP. Palladium-based mass tag cell 
medRxiv preprint doi: https://doi.org/10.1101/2021.07.29.21261325; this version posted August 1, 2021. The copyright holder for this preprint (which was not certified by peer review) is the author/funder, who has granted medRxiv a license to display the preprint in perpetuity.

It is made available under a CC-BY 4.0 International license .

barcoding with a doublet-filtering scheme and single-cell deconvolution algorithm. Nature protocols. 2015;10(2):316-33. Epub 2015/01/23. doi: 10.1038/nprot.2015.020. PubMed PMID: 25612231; PMCID: PMC4347881.

59. Schuyler RP, Jackson C, Garcia-Perez JE, Baxter RM, Ogolla S, Rochford R, Ghosh D, Rudra P, Hsieh EWY. Minimizing Batch Effects in Mass Cytometry Data. Front Immunol. 2019;10:2367. Epub 2019/11/05. doi: 10.3389/fimmu.2019.02367. PubMed PMID: 31681275; PMCID: PMC6803429.

60. Nemkov T, Reisz JA, Gehrke S, Hansen KC, D'Alessandro A. High-Throughput Metabolomics: Isocratic and Gradient Mass Spectrometry-Based Methods. Methods in molecular biology. 2019;1978:13-26. Epub 2019/05/24. doi: 10.1007/978-1-4939-9236-2_2. PubMed PMID: 31119654.

61. Huber W, Carey VJ, Gentleman R, Anders S, Carlson M, Carvalho BS, Bravo HC, Davis S, Gatto L, Girke T, Gottardo R, Hahne F, Hansen KD, Irizarry RA, Lawrence M, Love MI, MacDonald J, Obenchain V, Oles AK, Pages H, Reyes A, Shannon P, Smyth GK, Tenenbaum D, Waldron L, Morgan M. Orchestrating high-throughput genomic analysis with Bioconductor. Nature methods.

2015;12(2):115-21. Epub 2015/01/31. doi: 10.1038/nmeth.3252. PubMed PMID: 25633503; PMCID: PMC4509590.

62. R Core Team. R: A Language and Environment for Statistical Computing. Vienna, Austria: R Foundation for Statistical Computing; 2020.

63. RStudio Team. RStudio: Integrated Development for R. Boston, MA: RStudio, PBC; 2020.

64. Bushnell B, Rood J, Singer E. BBMerge - Accurate paired shotgun read merging via overlap. PLoS One. 2017;12(10):e0185056. Epub 2017/10/27. doi: 10.1371/journal.pone.0185056. PubMed PMID: 29073143; PMCID: PMC5657622.

65. Kim D, Paggi JM, Park C, Bennett C, Salzberg SL. Graph-based genome alignment and genotyping with HISAT2 and HISAT-genotype. Nature biotechnology. 2019;37(8):907-15. Epub 2019/08/04. doi: 10.1038/s41587-019-0201-4. PubMed PMID: 31375807.

66. Li H, Handsaker B, Wysoker A, Fennell T, Ruan J, Homer N, Marth G, Abecasis G, Durbin R, Genome Project Data Processing Subgroup. The Sequence Alignment/Map format and SAMtools. 
medRxiv preprint doi: https://doi.org/10.1101/2021.07.29.21261325; this version posted August 1, 2021. The copyright holder for this preprint (which was not certified by peer review) is the author/funder, who has granted medRxiv a license to display the preprint in perpetuity.

It is made available under a CC-BY 4.0 International license .

Bioinformatics. 2009;25(16):2078-9. doi: 10.1093/bioinformatics/btp352. PubMed PMID: 19505943; PMCID: PMC2723002.

67. Anders S, Pyl PT, Huber W. HTSeq--a Python framework to work with high-throughput sequencing data. Bioinformatics. 2015;31(2):166-9. doi: 10.1093/bioinformatics/btu638. PubMed PMID: 25260700; PMCID: 4287950.

68. Love MI, Huber W, Anders S. Moderated estimation of fold change and dispersion for RNA-seq data with DESeq2. Genome biology. 2014;15(12):550. doi: 10.1186/s13059-014-0550-8. PubMed PMID: 25516281; PMCID: 4302049.

69. De Livera AM, Dias DA, De Souza D, Rupasinghe T, Pyke J, Tull D, Roessner U, McConville M, Speed TP. Normalizing and integrating metabolomics data. Anal Chem. 2012;84(24):10768-76. Epub 2012/11/16. doi: 10.1021/ac302748b. PubMed PMID: 23150939.

70. Chen H, Lau MC, Wong MT, Newell EW, Poidinger M, Chen J. Cytofkit: A Bioconductor Package for an Integrated Mass Cytometry Data Analysis Pipeline. PLoS Comput Biol. 2016;12(9):e1005112. Epub 2016/09/24. doi: 10.1371/journal.pcbi.1005112. PubMed PMID: 27662185; PMCID: PMC5035035.

71. Hahne F, LeMeur N, Brinkman RR, Ellis B, Haaland P, Sarkar D, Spidlen J, Strain E, Gentleman R. flowCore: a Bioconductor package for high throughput flow cytometry. BMC bioinformatics. 2009;10:106. Epub 2009/04/11. doi: 10.1186/1471-2105-10-106. PubMed PMID: $19358741 ;$ PMCID: PMC2684747.

72. Krijthe J. Rtsne: T-Distributed Stochastic Neighbor Embedding using a Barnes-Hut Implementation. 2015.

73. Valikangas T, Suomi T, Elo LL. A systematic evaluation of normalization methods in quantitative label-free proteomics. Brief Bioinform. 2018;19(1):1-11. Epub 2016/10/04. doi: 10.1093/bib/bbw095. PubMed PMID: 27694351; PMCID: PMC5862339.

74. Chong J, Wishart DS, Xia J. Using MetaboAnalyst 4.0 for Comprehensive and Integrative Metabolomics Data Analysis. Curr Protoc Bioinformatics. 2019;68(1):e86. Epub 2019/11/23. doi: 10.1002/cpbi.86. PubMed PMID: 31756036. 
medRxiv preprint doi: https://doi.org/10.1101/2021.07.29.21261325; this version posted August 1, 2021. The copyright holder for this preprint (which was not certified by peer review) is the author/funder, who has granted medRxiv a license to display the preprint in perpetuity.

It is made available under a CC-BY 4.0 International license.

75. Subramanian A, Tamayo P, Mootha VK, Mukherjee S, Ebert BL, Gillette MA, Paulovich A,

Pomeroy SL, Golub TR, Lander ES, Mesirov JP. Gene set enrichment analysis: a knowledge-based approach for interpreting genome-wide expression profiles. Proc Natl Acad Sci U S A.

2005;102(43):15545-50. doi: 10.1073/pnas.0506580102. PubMed PMID: 16199517; PMCID:

PMC1239896.

76. Sergushichev AA. An algorithm for fast preranked gene set enrichment analysis using cumulative statistic calculation. bioRxiv. 2016:060012. doi: 10.1101/060012.

77. Harrell FEH. Hmisc: Harrell Miscellaneous. 2020.

78. Gu Z, Eils R, Schlesner M. Complex heatmaps reveal patterns and correlations in multidimensional genomic data. Bioinformatics. 2016;32(18):2847-9. Epub 2016/05/22. doi:

10.1093/bioinformatics/btw313. PubMed PMID: 27207943.

79. Wickham H. ggplot2: Elegant Graphics for Data Analysis: Springer-Verlag New York; 2016.

80. Cribari-Neto F, Zeileis A. Beta Regression in R. Journal of statistical software. 2010;34(2):24. Epub 2010-04-05. doi: 10.18637/jss.v034.i02.

81. Lüdecke D. ggeffects: Tidy Data Frames of Marginal Effects from

Regression Models. The Journal of Open Source Software. 2018;3(26):772. doi: 10.21105/joss.00772. 